\title{
Eocene post-rift tectonostratigraphy of the Rockall Plateau, Atlantic margin of NW Britain: linking early spreading tectonics and passive margin response
}

\author{
M S Stoker ${ }^{\mathrm{a}}$, G S Kimbell ${ }^{\mathrm{b}}$, D B McInroy ${ }^{\mathrm{a}}$, A C Morton ${ }^{\mathrm{c}, \mathrm{d}}$ \\ a British Geological Survey, Murchison House, West Mains Road, Edinburgh,EH9 3LA, Scotland, UK( $\underline{\text { ms @ @bgs.ac.uk }}$; \\ dbm@bgs.ac.uk) \\ ${ }^{\mathrm{b}}$ British Geological Survey, Kingsley Dunham Centre, Keyworth, Nottingham, NG12 5GG, England, UK (gsk@bgs.ac.uk) \\ ${ }^{\mathrm{c}}$ HM Research Associates, 2 Clive Road, Balsall Common, CV7 7DW, England, UK \\ (a.c.morton@heavyminerals.fsnet.co.uk)) \\ ${ }^{d}$ CASP, University of Cambridge, 181a Huntingdon Road, Cambridge, CB3 ODH, England, UK
}

\section{CORRESPONDING AUTHOR:}

M S Stoker: Address: British Geological Survey, Murchison House, West Mains Road, Edinburgh, EH9 3LA, Scotland, UK; e-mail: mss@ bgs.ac.uk; Tel: +44 (0)131 6500374 (direct line); Fax: +44 (0)131 6681000

\begin{abstract}
A regional study of the Eocene succession in the UK sector of the Rockall Plateau has yielded new insights into the early opening history of the NE Atlantic continental margin. Data acquired from British Geological Survey borehole 94/3, on the Rockall High, provides a high-resolution record of post-rift, Early to Mid-Eocene, subaqueous fan-delta development and sporadic volcanic activity, represented by pillow lavas, tuffs and subaerial lavas. This sequence correlates with the East Rockall Wedge, which is one of several prograding sediment wedges identified across the Rockall Plateau whose development was largely terminated in the mid-Lutetian. Linking the biostratigraphical data with the magnetic anomaly pattern in the adjacent ocean basin indicates that this switch-off in fandelta sedimentation and volcanism was coincident with the change from a segmented/transform margin to a continuously spreading margin during chron C21. However, late-stage easterly prograding sediment wedges developed on the Hatton High during late Mid- to Late Eocene times; these can only
\end{abstract}


have been sourced from the Hatton High, which was developing as an anticline during this interval. This deformation occurred in response to Mid- to Late Eocene compression along the ocean margin, possibly associated with the reorganisation to oblique spreading in the Iceland Basin, which culminated at the end of the Eocene with the formation of the North Hatton Anticline, and the deformation (tilting) of these wedges. A series of intra-Eocene unconformities, of which the midLutetian unconformity is the best example, has been traced from the Rockall Plateau to the FaroeShetland region and onto the Greenland conjugate margin bordering the early ocean basin. Whilst there appears to be some correlation with $3^{\text {rd }}$ order changes in eustatic sea level, it is clear from this study that tectonomagmatic processes related to changes in spreading directions between Greenland and Eurasia, and/or mantle thermal perturbations cannot be discounted.

Keywords: Rockall Plateau; NE Atlantic; Eocene post-rift tectonostratigraphy; passive margin tectonics; early ocean basin spreading.

\section{Introduction}

The Rockall Plateau is an area of complex bathymetry on the outer continental margin, west of Britain and Ireland. It is separated from the main NW European shelf to the east by the Rockall Basin, and is bounded to the west by the oceanic Iceland Basin (Fig. 1). The plateau is dominated by the NE-trending bathymetric features of Rockall Bank, Hatton Bank and the intervening Hatton Basin; the underlying geological structures have been termed the Rockall High, Hatton High and Hatton Basin, respectively (Naylor et al., 1999; Ritchie et al., 2012). The smaller George Bligh Bank, and the Edoras, Fangorn and Lorien banks occur along the NE and SW margins, respectively, of the plateau; as structural features, these are also referred to as 'highs'. This complex bathymetry is ultimately a reflection of the crustal thickness variations due to rifting and magmatism that culminated in the separation of Europe 
and Greenland in the Early Eocene (e.g. Skogseid et al., 2000). Along the Rockall Plateau, continental breakup occurred along the western flank of the Hatton High, which is characterised by large volumes of extrusive volcanism and other extrusive volcanic structures (Hinz, 1981; Roberts et al., 1984; White, 1992; Planke et al., 2000; Menzies et al., 2002). Consequently, most research into the tectonic evolution of the Rockall Plateau has been heavily focused on the structure and formation of the western part of the plateau, in the context of a volcanic rifted margin (Fowler et al., 1989; Morgan et al., 1989; Spence et al., 1989; White and McKenzie, 1989; Smith et al., 2005; Elliott and Parson, 2008; White and Smith, 2009). In contrast, very little has been published about the post-rift history of the Rockall Plateau. For several decades, its topographic relief has been largely attributed to differential thermal subsidence (Roberts et al., 1984), based on the general acceptance that the only significant post-rift tectonic process experienced by passive margins is lithospheric cooling, expressed by a simple uninterrupted thermal sag pattern of subsidence (Sleep, 1971; McKenzie, 1978; White et al., 2003). However, from observations on divergent margins around the world it is becoming increasingly apparent that passive continental margins are not so passive. There is geophysical evidence from young oceanic basins, such as the Woodlark Basin off Papua New Guinea (Taylor et al., 1995; Martinez et al., 1999), that rifting of the conjugate margins may continue after the inception of seafloor spreading, i.e. continental rifting does not immediately cease when seafloor spreading begins. Moreover, there is stratigraphical and structural evidence offshore NW Europe (e.g. Doré and Lundin, 1996; Stoker, 1997; Doré et al., 1999; Stoker et al., 2001, 2005a; Hitchen, 2004; Ceramicola et al., 2005; Johnson et al., 2005; Praeg et al., 2005; Holford et al., 2009; Tuitt et al., 2010), Brazil (Cobbold et al., 2001), West Africa (Hudec and Jackson, 2002) and southern Australia (Holford et al., 2011) for complex phases of differential subsidence and/or exhumation and fold development throughout the post-rift period. 
A key stratigraphic marker for the Rockall Plateau and Basin is the Late Eocene angular unconformity (reflector C30 of Stoker et al. 2001), which enables two important post-rift tectonic events to be identified: 1) the rapid subsidence of the Rockall and Hatton basins and the concomitant collapse of the shelf-margin bordering the Rockall High, which created the present-day deep-water basins (Stoker, 1997; Stoker et al., 2001); and, 2) the formation of the Hatton High fold complex (Hitchen, 2004; Johnson et al., 2005). The stratigraphic data indicate that this phase of crustal shortening and sagging was co-eval with the formation of the Late Eocene unconformity, and both the deformation and the development of this tectonic unconformity have been interpreted in terms of the passive margin (intraplate) response to a major North Atlantic plate reorganisation that saw the termination of seafloor spreading in the Labrador Sea (Stoker et al., 2001; Holford et al., 2009). Whereas subsequent (postEocene) phases of intraplate deformation (primarily folding) have been documented widely along the length of the NW British and the Faroese margins (Boldreel and Andersen, 1993, 1998; Ritchie et al., 2003; Smallwood, 2004; Johnson et al., 2005; Stoker et al., 2005b; Ritchie et al., 2008), there is a general lack of information regarding the tectonostratigraphic setting of the earlier post-rift (intra-Eocene) period, immediately following continental breakup, though some authors claim that compressional deformation has been active since the time of breakup (e.g. Boldreel and Andersen, 1993, 1998; Smallwood, 2004).

Only limited borehole data have previously been collected and published for the Eocene succession on the Rockall Plateau, acquired as part of two Deep Sea Drilling Project (DSDP) cruises to this area in the 1970's and 80's. In the Irish sector, the rift-to-drift transition was cored at a series of DSDP sites across the continent-ocean boundary, on the SW Rockall Plateau (Fig. 1). DSDP sites 403 and 404, and 552-555 proved a record of subaerial to 
shallow marine lavas, tuffs and intercalated clastic sediment of latest Paleocene-earliest Eocene age, sharply overlain by a punctuated sequence of deeper-water mudstone and limestone deposited as the margin rapidly subsided following breakup (Montadert et al., 1979; Roberts et al., 1984). These sites are currently located in water depths $>2 \mathrm{~km}$. In the UK sector, DSDP sites 116 and 117 drilled Upper Eocene limestone and Lower Eocene sandstone and mudstone, respectively, in the Hatton Basin (Laughton et al., 1972). Site 116 in the centre of the basin was terminated at this stratigraphic level, whereas site 117 was drilled on the flank of the basin where a major hiatus separates Lower Eocene and Lower Oligocene rocks; thus, the major part of the basinal Eocene succession remains untested. Both of these sites are located at a water depth $>1 \mathrm{~km}$.

By way of contrast, a regional mapping programme undertaken between 1992 and 2000 by the British Geological Survey (BGS) acquired seismic data, continuously-cored boreholes and shorter rockdrill cores on behalf of the BGS Rockall Consortium (see Acknowledgements) in the UK sector (Fig. 2). From the seismic dataset, a series of prograding clastic sediment wedges - herein defined as mainly shallow-marine packages of prograding clinoforms - was identified and mapped at various stratigraphic levels between the top of the breakup lava sequence and the Late Eocene unconformity (C30 reflector) (Stoker and Hitchen, 1995; Hitchen, 2004; McInroy et al., 2006). On the Rockall High, one of the thickest wedges - the East Rockall Wedge (not to be confused with a separate PlioPleistocene deposit, formerly assigned the same name by Stoker et al. 2005b) - has been drilled by BGS borehole 94/3, which revealed a record of Eocene post-rift clastic sedimentation and volcanism punctuated by subaerial unconformities (Stoker, 1995a). However, despite initial shipboard observation and reporting to the Rockall Consortium, no further work was undertaken on this borehole. In view of the proven sensitivity of this 
Eocene record to changes in relative sea level, it was decided to re-visit this dataset in order to shed new light on the early post-rift tectonostratigraphic setting of this mature passive margin. Unlike many other mature margins where the record of early breakup is commonly masked, at depth, beneath a thick post-rift sediment cover, the prograding clastic wedges on the Rockall Plateau provide an accessible window into the early post-rift history, including the rift-to-drift transition, of the NW British margin. To achieve this objective, we have:

- Re-logged BGS borehole 94/3 in terms of its sedimentology, and fully integrated the results - for the first time - with specialist biostratigraphical, petrographical, heavy mineral and palaeomagnetic analyses undertaken since its collection. The borehole has also been better calibrated to seismic data that have been enhanced, particularly in terms of their amplitude display, since the initial reporting of the borehole;

- Reappraised the prograding sediment wedges identified on the Rockall margin (including the George Bligh High), especially in terms of their relative chronology. We have utilised information derived from borehole 94/3, as well as other BGS Rockall Consortium borehole data in this area (94/2, 94/6 and 94/7);

- Compared the Eocene record on the Rockall Plateau with the SE Greenland and FaroeShetland margins in order to evaluate change on both sides of the early ocean basin;

- Investigated the nature of the Eocene ocean crust in order to assess any common linkage between the development of the ocean basin and the adjacent margin.

From a petroleum exploration perspective, Eocene clastic wedges in the North Sea Basin (Fig. 1) form part of a proven hydrocarbon system (Jones et al., 2003). By way of contrast, the main industry focus on the UK Atlantic margin has been the deep-water Paleocene sandstone play (Quinn et al., 2011). A Mid-Eocene basin-floor fan play has been recognised 
in the Faroe-Shetland Basin (Davies et al., 2004; Quinn et al., 2011), but it has, to date, been largely associated with generally poor hydrocarbon indications, and as a consequence the Eocene succession in the deep-water Atlantic margin basins has been little studied in terms of its prospectivity. Although the clastic wedges on the Rockall Plateau are largely perceived as having low hydrocarbon potential, due to their shallow depth of burial (McInroy et al., 2006), their geometry, composition, provenance and tectonic setting may provide analogue information for the deeper-buried deposits in the adjacent Rockall and Faroe-Shetland basins.

\section{BGS Borehole 94/3}

Borehole 94/3 was drilled on the eastern flank of the Rockall High, and penetrated $198.10 \mathrm{~m}$ into the Eocene East Rockall Wedge, which is preserved along the outer part of the high beneath a thin cover (11.55 m) of Quaternary sediment (Figs. 2 and 3a,b). Biostratigraphical analysis indicates at least three main pulses of Eocene deposition are represented in the borehole, constrained within the following biozone ranges: NP10-11 (early Ypresian); NP12-14 (late Ypresian-early Lutetian); and NP16-17 (late Lutetian-Bartonian) (Table 1). Although previous studies have stated that the base of the wedge was cored in 94/3 (Stoker, 1995a; McInroy et al. 2006), re-inspection of the seismic profile data in this study suggests that only about two-thirds of the wedge was penetrated. Thus, the age of the oldest deposits remains unknown. Paleocene calcareous nannofossils (NP4-5/6) have been recovered from the basal sediments within the borehole. In the context of the borehole these are probably reworked, though their presence may have significance for extending the lower age range of the East Rockall Wedge. 
The chronological control provided by the stratigraphical range of the biozones gives an estimation of the duration of each of the main depositional pulses to between 2-6 My $-\mathrm{a}$ typical $3^{\text {rd }}$ order cycle. However, detailed logging of borehole $94 / 3$ reveals a higher frequency of deposition superimposed on these cycles, expressed as facies changes, intermittent volcanic activity and erosional breaks. A total of twelve depositional units are identified within the borehole: unit 1 is the Quaternary; units 2-12 represent the Eocene (Fig. 4). A further thirteen sub-units $(2 \mathrm{a}-\mathrm{c} ; 7 \mathrm{a}-\mathrm{f} ; 10 \mathrm{a}-\mathrm{d})$ are distinguished within the Eocene section. All borehole depths cited in the text are referenced with respect to the sea bed.

In general terms, the cored Eocene succession is dominated by sandstone with high volcaniclastic grain (both basaltic and acidic varieties) contents. The volcanic grains commonly include altered glass (some amygdaloidal), finely crystalline basalt and $\mathrm{K}$ feldspar-rich grains (cf. Lott, 1995). Between 135.92 and 207.94 m (units 8 to 11), medium to coarse-grained sandstone is interbedded with conglomerate; above $135.92 \mathrm{~m}$ (units 2-3, 5-7), the sandstone is generally finer grained. Shoreface and subaqueous mass-flow deposits are interpreted to comprise much of the wedge. In addition, three significant phases of volcanic activity have been proved: 1) pillow lavas occur at the base of the borehole (unit 12: 207.94$209.65 \mathrm{~m}$ ), and may comprise much of the un-cored lower third of the East Rockall Wedge; 2) a subaqueous tuffaceous section occurs between 88.62 and $135.92 \mathrm{~m}$ (unit 7); and, 3) a subaerial lava occurs between 47.26 and $51.00 \mathrm{~m}$ (unit 4). A thin (5 mm), black, cross-cutting glassy layer was also noted between 145.53 and $145.56 \mathrm{~m}$. Palaeomagnetic analysis of the pillow lavas (unit 12) and the subaerial lava flow (unit 4) revealed that polarity was reversed during their extrusion (Bannister, 1995). On current evidence, the magnetisation of the pillow lavas is likely to correlate with polarity chron C24R, whereas the upper lava is correlated to C21R. 
The borehole record indicates marked fluctuations in relative sea level which, together with evidence for syn-sedimentary deformation and the stratal architecture of the wedge (see below), may be indicative of active tectonics during the accumulation of the wedge. A significant deepening of the Rockall Basin is known to have occurred at the end of the Eocene that resulted from a major basin-margin flexure (Stoker et al., 2001; Praeg et al., 2005).

A detailed description of each lithological unit/sub-unit is presented in Table 2, and shown graphically in Figure 4. The sedimentological distinction between shoreface and offshore marine deposits is based on the criteria of Reineck and Singh (1980) and McCubbin (1982). The shoreface deposits are predominantly sandy with an increase in grain size, ripple crosslamination and scouring, and a decrease in bioturbation indicative of the transition from the lower to upper shoreface setting. The offshore marine deposits are predominantly muddy and bioturbated, with sporadic thin-bedded sand units. The dinoflagellate cyst and foraminiferal assemblages indicated in Table 1 are especially indicative of a coastal to nearshore marine environment. Correlation between the borehole and the seismic profile across the East Rockall Wedge is shown in Figure 3. A summary of the key aspects of the succession, incorporating the seismic data, is presented below, in ascending stratigraphical order.

\subsection{Lithological description}

2.1.1. Unit 12 (207.94-209.65 m TD) 
The basal unit consists of three pillow lavas, up to $0.45 \mathrm{~m}$ thick, of sub-alkaline basalt composition separated by two, bioturbated and shelly mudstone beds, $0.2-0.5 \mathrm{~m}$ thick. This section is interpreted to have formed in an offshore marine setting. On the seismic profile, unit 12 forms the upper part of a complex mounded to hummocky seismic facies with abundant, discontinuous, high-amplitude reflections that characterise the lower third of the East Rockall Wedge (Fig. 3a, b). The boundary with unit 11 is a high-amplitude, irregular reflector that is downlapped by the overlying strata. In the borehole, this represents the sharp contact with the overlying shallow-water sandstone of unit 11 , which includes possible reworked basaltic gravel clasts at its base (Fig. 4). This relationship implies a significant shallowing (and possible exposure) of the depositional environment, and the boundary is interpreted as a type 1 sequence boundary (sensu van Wagoner et al., 1988; Emery and Myers, 1996).

By their very nature, pillow lavas must be derived from a local source. It is not inconceivable that the highly faulted and fractured basement beneath the East Rockall Wedge (Fig. 3a, b), which may be a consequence of Mesozoic faulting at the basin margin (cf. Naylor et al., 1999), facilitated fissure eruption at this time.

\subsubsection{Units $10 \& 11(145.00-207.94 \mathrm{~m})$}

These units form the bulk of the lower Ypresian section cored by the borehole. They are dominated by coarse-grained facies that appear to display a general upwards-coarsening trend from $207.94 \mathrm{~m}$ to $171.72 \mathrm{~m}$, followed by several decimetre-scale normally graded packages to $145.00 \mathrm{~m}$ (Fig. 4). Numerous centimetre-scale normal and reverse graded beds are superimposed on this overall cycle. In unit 11, parallel and cross-bedded, bioturbated shelly 
sandstone beds alternate with more massive and disorganised beds of shelly sandstone; the former are interpreted as shoreface deposits, whereas the latter probably represent subaqueous mass-flow deposits that become predominant in the overlying unit 10 . The contact with sub-unit $10 \mathrm{~d}$ is transitional and reversely graded, and marks an increase in gravel and a reduction in bioclasts within the overlying massive to crudely bedded, thin- to thickbedded conglomerate-sandstone couplets. Sub-unit 10c includes very thick beds of conglomerate that locally display irregular bases - channelised incision - cut into underlying sandstone beds, which are commonly laminated. Sub-unit $10 \mathrm{~b}$ is a cobble-grade conglomerate that rests in erosional contact on 10c, and includes rip-up clasts of bioturbated mudstone and siltstone, and shelly sandstone, as well as the ubiquitous volcaniclastic component. Sub-unit $10 a$ consists of massive and laminated sandstone, with common shelly fragments.

Unit 11 represents a transition from shoreface to mass flow deposition. The seismic profile shows a predominance of prograding clinoforms that - on the evidence of unit 10 - largely comprise coarse-grained facies with sporadic shell debris.

\subsubsection{Unit $9(141.33-145.00 \mathrm{~m})$}

Unit 9 is dominated by bioturbated, red-brown (upper) to grey-green (lower) mudstone with subordinate fine-grained, thin-bedded sandstone that depicts parallel to cross-bedding. The contact with sub-unit 10a is sharp, and marked by rapid normal grading from underlying shelly sandstone into finer-grained laminated sandstone at the base of unit 9 . The heterolithic nature of unit 9 , together with sharp and commonly erosive bed contacts, implies deposition from traction (bed load) and suspension processes. Evidence of soft sediment deformation (loaded bases, sand injection structures) suggests that deposition was rapid and/or occurred 
on an unstable surface. This unit is interpreted to comprise thin-bedded distal turbidites. Despite the general lack of shell material, the presence of marine microplankton confirms marine deposition.

The sharp change between units 10 and 9 is inferred to mark a flooding surface, i.e. a sudden deepening of the depositional surface at this location. However, this change is not obviously expressed on the seismic profile, most probably due to the thin nature of the unit (Fig. 3a,b). The significance of the colour variation in the mudstone is unclear. It probably reflects an oxidising environment at the place of deposition, albeit having undergone subsequent partial reduction. However, it should be noted that Lower Eocene red clay has also been recovered between Rockall Bank and George Bligh Bank, with the colour attributed to provenance, i.e. weathering of intermediate igneous rocks (Ferragne et al., 1984).

\subsubsection{Unit 8 (135.92-141.33 m)}

Unit 8 consists of medium- to coarse-grained shelly sandstone. Bi-directional tabular crossbedding, scour surfaces and shell lags all suggest an upper shoreface environment of deposition. The contact with unit 9 is very sharp and indicates a rapid shallowing. The upper $30 \mathrm{~cm}$ of the unit is heavily bioturbated and stained yellow-brown (contrasting with the general buff to grey colour); the contact with the overlying unit 7 is very sharp and irregular. We interpret this to indicate subaerial exposure of unit 8 prior to the deposition of unit 7 . On the seismic profile, this boundary coincides with an irregular, high-amplitude reflector that is designated as a type 1 sequence boundary (sensu van Wagoner et al., 1988; Emery and Myers, 1996). 


\subsubsection{Unit 7 (88.62-135.92 m)}

Unit 7 is characterised by the accumulation of vitric, andesitic, commonly altered tuffaceous material that increases in abundance in the upper part of the unit. Six sub-units have been defined that reflect the variable association of the tuffs with the background sediments, both intermixed, and interbedded, with the siliciclastic material, indicative of some degree of reworking (Fig. 4). On the seismic profile, this unit displays a progradational, oblique-parallel to chaotic seismic facies.

Sub-unit $7 f$ is $0.97 \mathrm{~m}$ thick and consists of an interbedded sequence of sandstone, siltstone and tuff. The latter occurs as a thin bed between 135.85 and $135.9 \mathrm{~m}$, and represents the first indication of pyroclastic activity at this location. Bi-directional tabular and trough crossbedding, grading, scouring and mud drapes on rippled surfaces are indicative of subaqueous deposition. Siltstone beds are locally red-brown. Slumped bedding indicates depositional instability. Sub-unit 7e is $11.35 \mathrm{~m}$ thick and rests with erosional contact on $7 \mathrm{f}$. It consists mainly of fine-grained sandstone with subordinate siltstone and mudstone. The sandstone is predominantly massive and bioturbated with only remnants of lamination and rare shell fragments; bioturbation is commonly in the form of black-stained sub-vertical pipes. Siltstone beds display small-scale ripples. The base of the sub-unit is marked by a $0.18 \mathrm{~m}$ thick 'conglomerate', composed of rip-up clasts of siltstone in a fine-grained sandstone matrix. Tuffaceous fragments appear at $124.7 \mathrm{~m}$, and are common above this depth. The top of 7e is highly bioturbated and all primary structure is lost. A mid- to lower shoreface setting is envisaged.

Sub-unit $7 d$ is a $2.05 \mathrm{~m}$-thick greyish green tuffaceous section with only minor siliciclastic content, though thin detrital layers locally display cross-bedding. This implies a subaqueous 
setting. The top of the sub-unit is varicoloured - black, greyish green, yellow-brown - and may be a weathered top. This is sharply overlain by a 3.96 m-thick section of stacked, graded, pebbly sandstone and conglomerate that comprise sub-unit $7 c$. The main accumulation of tuffaceous material occurs in sub-units $7 b$ and $7 a$; in $7 \mathrm{~b}(110.00-117.59 \mathrm{~m})$, tuffaceous material is predominant with subordinate interbedded sandstone (single grain to $2 \mathrm{~cm}$ thick), whereas the frequency and thickness of sandstone beds increases in $7 \mathrm{a}(88.62-110.00 \mathrm{~m})$, though the recovery in this interval of the borehole is poor. Correlation with prograding reflections (Fig. 3a,b) implies a subaqueous mass-flow origin for the sub-units. The uppermost part of sub-unit $7 \mathrm{a}$ is marked by a 0.23 m-thick, iron-stained bed, which incorporates the underlying material, igneous pebbles, and the overlying sandstone (unit 6) preserved in burrows and/or fissures within the bed. This bed resembles the B-horizon of a soil. On the seismic profile, a medium amplitude reflector marks this horizon, and is assigned as a type 1 sequence boundary (sensu van Wagoner et al., 1988; Emery and Myers, 1996).

\subsubsection{Units $4-6(47.26-88.62 \mathrm{~m})$}

Unit 6 extends between 58.00 and $88.62 \mathrm{~m}$, though the upper contact with unit 5 is inferred. It mainly consists of very fine- to medium-grained sandstone, with sporadic shells and common bioturbation. Siltstone and red-brown mudstone beds are medium to thin and bioturbated. A shoreface depositional environment is envisaged. Sandstone and conglomerate form the overlying unit $5(51.00-58.00 \mathrm{~m})$, with clasts up to cobble grade. The disorganised nature of the sediment suggests a mass flow origin. On the seismic profile, these two units are associated with a wedge-shaped package that both downlaps (seaward) and onlaps (landward) onto the underlying unit 7. This implies that the underlying section may have been tilted basinward prior to the deposition of unit 6 . The top of this wedge is marked by a high- 
amplitude reflection that most probably represents the lava flow of unit 4, interpreted as subaerial in origin (Morton 1995a). As with the pillow lavas of unit 12, the composition of the lava flow is sub-alkaline basalt. The base of the flow was not recovered in the borehole; however, the top appears to be sharply overlain by the sandstone of unit 3 . This boundary is interpreted as a type 1 sequence boundary (sensu van Wagoner et al., 1988; Emery and Myers, 1996).

\subsubsection{Units $3 \& 2(11.55-47.26 \mathrm{~m})$}

Both of these units consist of very fine- to fine-grained sandstone that is shelly and bioturbated, and interpreted as shoreface deposits. The overall poor recovery precludes detailed assessment of the section; however, a basalt cobble appears to separate units 3 and 2 . This probable lag deposit also marks a biostratigraphical break. Correlating the borehole record with the seismic profile remains ambiguous. In our interpretation, unit 3 is inferred to comprise a prograding seismic facies that has been truncated prior to the deposition of the flatter-lying sheet-like deposit of unit 2. The flat-lying nature of the truncation surface may be indicative of erosion, though it is uncertain whether this represents a regressive lag or a marine lag at the base of a marine transgression. Traced onto the Rockall High, this unconformity is a composite surface that also incorporates the lava flow of unit 4 , and appears to correspond to a distinct step on the sea bed (Fig. 3a,b). The internal seismic character of unit 2 is largely obscured by the sea bed pulse, and it is unclear whether unit 2 drapes this terraced surface, or whether higher-resolution data would reveal a different seismic configuration. In the borehole, the division of unit 2 into sub-units $2 a-2 c$ is more a reflection of the lack of information in the middle part of this unit, with $2 \mathrm{~b}$ comprising a few 
cobbles separating sandstone sections $2 \mathrm{a}$ and $2 \mathrm{c}$. The top of unit 2 is marked by an erosional, bioturbated contact that is overlain by thin (11.55 m) Quaternary deposits (unit 1).

2.2. Summary of heavy mineral analysis: implications for provenance

Four samples have previously been studied in terms of their heavy mineral content: $181.56 \mathrm{~m}$ (sub-unit 10d); $125.6 \mathrm{~m}$ (sub-unit 7e); $72.9 \mathrm{~m}$ (unit 6); $39.0 \mathrm{~m}$ (unit 3). The details of this analysis are summarised in Table 3, which is based on the original report to the Rockall Consortium by Morton (1995b).

The heavy mineral assemblages show a clear trend in provenance through time. The oldest sample (sub-unit 10d) has a basaltic source (supplying the abundant clinopyroxene), with a subsidiary recycled (older) sedimentary component (represented by garnet and zircon). The clinopyroxene has a restricted compositional range suggesting that it was sourced locally. However, it has a lower Ti content than the clinopyroxene in the pillow lavas of unit 12, indicating that these are not their source. This is entirely consistent with the stratigraphical relationship between unit 12 and the overlying fan-delta, which was most probably sourced farther to the west on the Rockall High. The petrographical and mineralogical analysis of a basalt pebble from sub-unit 10c, which differs in both texture and clinopyroxene composition from the pillow lavas of unit 12 (Morton, 1995a), concurs with the conclusion that the conglomerate was not derived from the immediate vicinity of the borehole. The nature and age of the older sedimentary component is unknown.

The recycled sedimentary component becomes insignificant in the overlying samples, which are dominated by basaltic sources in sub-unit 7e, and a mixture of alkaline and basaltic 
sources in units 6 and 3. In general terms, the clinopyroxenes in all of these samples show a broader compositional range than that in sub-unit $10 \mathrm{~d}$, which may indicate derivation from a larger and inevitably more heterogeneous basaltic terrain. The incorporation of alkaline minerals within units 6 and 3 represents a major change in the heavy mineral component of the upper part of the fan-delta. Abundant aegirine, sodic amphibole and sodic-calcic amphibole in unit 6 provide the first record of alkaline magmatic activity in this sedimentary sequence. Although this assemblage is similar in composition to that of the Rockall aegirine granite (that forms Rockall islet: Fig. 1), a Rb-Sr date of 52 $\pm 8 \mathrm{Ma}$ (Hawkes et al., 1975) is closely comparable with the biostratigraphically-constrained age of unit 6 . This suggests that the alkaline detritus was not derived directly by erosion of the Rockall granite, as this would have taken several million years to become unroofed following intrusion. It is more likely that the detritus was introduced by the erosion of alkaline flows or by explosive volcanism, and represents a subaerial manifestation of the arrival of alkaline magmas, probably coeval with the emplacement of the Rockall igneous centre.

Unit 3 is characterised by a heterogeneous suite of heavy minerals dominated by basaltic detritus and a more varied assemblage of alkaline minerals than in unit 6 (Table 3). The increased basaltic detritus is of no surprise considering the phase of basalt extrusion preserved as unit 4 . The alkaline suite is unusual in that it contains aenigmatite, which is typically found in peralkaline volcanic rocks, pegmatites, granites and silica-poor intrusive rocks. Although aenigmatite-bearing rocks are not currently known from the Rockall igneous centre, its paragenesis indicates it is almost certainly genetically related to the Rockall alkaline suite. Its presence in unit 3 is therefore interpreted to be due to the erosion of material related to the Rockall igneous centre. 


\subsection{Development of the East Rockall Wedge}

In Figure 3c, the East Rockall Wedge has been deconstructed on a Wheeler (chronological) diagram into its various components (units 2-12) to reveal its temporal and spatial development. Although the chronological range of the various units is constrained within the resolution of the biostratigraphical data (Table 1), the placement of the units in Figure 4 remains subjective. For example, using only palynological data, units 3-7 were correlated specifically to the NP12 biozone, between 51.7 and $52 \mathrm{Ma}$ (pre-onset of the Eocene thermal maximum) (Jolley, 1996). However, foraminiferal data suggest an NP13-14 range for the same section (Wilkinson, in Stoker 1995b).

Notwithstanding the accuracy of the biostratigraphical data, it is evident that the bulk of the East Rockall Wedge is of Early to early Mid-Eocene age, possibly extending back into the Late Paleocene. This is consistent with several Ar-Ar ages in the range of $56.5 \pm 0.1$ to $57.03 \pm 0.2 \mathrm{Ma}$ that have been reported from the sub-wedge lavas on Rockall High (Hitchen, 2004). Sequence boundaries of regional extent occur at the top of units 12, 8 and 4 (Stoker and Hitchen, 1995; McInroy et al., 2006), and a hitherto unrecognised sequence boundary is also recorded at the top of unit 7 . These boundaries represent intervals of significant shallowing (top unit 12) or subaerial exposure (top units $8,7,4$ ). Their association with phases of volcanic activity implies a tectonically and/or thermally active setting, and, in units 8-11, the transition from shoreface to coarse-grained mass-flow deposits is consistent with the progradation of a subaqueous fan-delta (Postma, 1995; Soh et al., 1995). The marked change in depositional setting may have been a response to uplift of the Rockall High. The fan-delta downlaps onto the bounding unconformity between units 12 and 11, which marks the cessation of fissure eruptions at this location, and the influx of coarse sandstone and 
conglomerate of units 11 and 10 implies uplift of the Rockall High at this time. Heavy mineral analysis indicates erosion of locally sourced basalts and older, undifferentiated, sediments from the exhumed high.

The subaerial exposure of unit 8 preceded a second major phase of subaqueous fan-delta progradation (unit 7), during which there was a renewal of volcanic activity in the form of pyroclastic tuff deposition. The suite of heavy minerals in sub-unit 7e (Table 3) implies that the general sediment source area may have been broadened relative to the sub-unit $10 \mathrm{~d}$ assemblage. However, tuffs within unit 7 differ in composition and texture when compared to those of the Balder Formation (Morton 1995a), indicative of a more local origin for the pyroclastic material. The overlying unit 6 shows evidence of both onlap and downlap onto the top of unit 7 , which suggests a further period of exposure accompanied by a phase of basinward tilting. The heavy mineral assemblage in unit 6 suggests that this may have been associated with alkaline volcanism elsewhere in the region. Following the deposition of the shoreface deposits of units 6 and 5, the subaerial lava flow of unit 4 was extruded. Although the present disposition of the lava flow dips basinward, there is no evidence to suggest that this is not the original angle of flow. Unit 3 may represent the final phase of fan-delta progradation, though its original extent is unclear due to its subsequent truncation. The heavy mineral assemblage in unit 3 implies that the Rockall High was being generally uplifted, possibly leading to the exposure of the Rockall igneous centre. The relationship of unit 2 (late Mid-Eocene age) to the fan-delta remains ambiguous.

The Eocene succession preserved in the East Rockall Wedge clearly reveals a history of nonuniform deposition, with phases of sedimentation punctuated by changes in relative sea level. The link between sedimentation and volcanic activity suggests that this episodicity is linked, 
at least in part, to tectonic activity. The main sedimentary component to the East Rockall Wedge is preserved in units $3-11$, which is interpreted as a subaqueous fan-delta that oversteps the pillow lava complex of unit 12. Sediment accumulation rates calculated for units 3 to 11 will likely show very low rates of accumulation given the resolution of a single biozone (1-2 Ma). However, it is probably valid to assume that, given non-uniform deposition, individual units accumulated in time intervals shorter than the range of the biozones. In Table 4, we present accumulation rates for the main phases of deposition (derived from the borehole and seismic data) spanning the range 0.1-1.0 Ma. For a duration of $0.1 \mathrm{Ma}$ the accumulation rates for each phase of deposition are moderate $(0.5-0.75 \mathrm{~mm} \mathrm{a}$ $\left.{ }^{1}\right)$. If the entire fan-delta package was deposited during a shorter period of time, as suggested by Jolley (1996), these rates would increase. For comparison, in the tectonically active Gulf of California, rates of sedimentation associated with Pliocene fan-delta development ranged from $5.5 \mathrm{~mm} \mathrm{a}^{-1}$ during the initial, rapid phase of basin subsidence, with rates decreasing to $<0.5 \mathrm{~mm} \mathrm{a}^{-1}$ over the next few million years (Johnson et al., 1983; Dorsey et al., 1995).

The presence of subaqueous fan-deltas on the flank of the Rockall High does not necessarily indicate that syndepositional tectonic activity controlled all of the accumulation of the East Rockall Wedge. Basinward tilting prior to the deposition of unit 6 is the only direct seismicstratigraphic expression of contemporary tectonism. However, the preservation of multiple, stacked, progradational sequences does imply that deposition of the entire wedge must have involved some degree of basin-margin subsidence to maintain accommodation space. Whilst the influence of glacio-eustatic changes in sea level, estimated to be between 15 and $30 \mathrm{~m}$ during the Late Cretaceous-Eocene interval (Miller et al., 2005), cannot be discounted, the differential relief on top of the subaerially eroded unit 8-11 fan-delta is much greater. 


\section{Rockall Plateau sediment wedges}

In addition to the East Rockall Wedge, at least ten other sediment wedges of varying size, extent and thickness $(70-400 \mathrm{~m})$ have been identified and mapped on the northern part of the Rockall Plateau, including the George Bligh High (Fig. 2). These wedges were originally described by McInroy et al. (2006); however, for the purpose of this paper, they have been reappraised in terms of their geometry and internal stratigraphic architecture, and have been placed within a preliminary chronostratigraphical context. In addition, each wedge has been assigned a name, which replaces the original numbering scheme deployed by McInroy et al. (2006).

3.1 Distribution and seismic stratigraphy

The East Rockall, North Rockall, NW Rockall and West Rockall wedges fringe the Rockall High, and their internal architecture indicates progradation away from the interior of the High into the adjacent Rockall and Hatton basins. The George Bligh Wedge progrades eastwards off the George Bligh High into the Rockall Basin. In contrast, the East Swithin, Lyonesse, East Lyonesse and Sandarro wedges are derived from igneous centres on the flanks of the Hatton Basin. The most extensive wedge is the North Hatton Wedge that extends just to the east of the axial crest of the North Hatton Anticline, and progrades to the SE. It overlies the Central Hatton Wedge in the central part of the Hatton High. The relative stratigraphic position of a number of these wedges is shown on a schematic transect constructed across the Rockall margin (Fig. 5). This transect indicates that whereas a number of wedges remain largely at sea bed at the present day (e.g. East Rockall, Lyonesse and North Hatton (part of) wedges), others (e.g. West Rockall, East Swithin, East Lyonesse and Central Hatton wedges) 
lie deeper within the section. Although facing each other, the East Swithin Wedge lies at a marginally higher stratigraphic level than the West Rockall Wedge. The North Hatton Wedge becomes increasingly buried by Neogene sediments when traced southwestwards along the Hatton High. The North and NW Rockall wedges, George Bligh Wedge and the Sandarro Wedge (not shown on Fig. 5) all essentially crop out at the sea bed (Figs. 6 and 7).

The main seismic-stratigraphic characteristics of each wedge are summarised in Table 5. In common with the East Rockall Wedge (section 2.3), the internal seismic reflections within all wedges reveal a strongly downlapping clinoform geometry (Figs. 6 and 7) associated with wedge progradation of between 5 and $30 \mathrm{~km}$. In detail, there are also indications of reflector truncation, aggradation and irregular erosion surfaces. The uppermost part of the NW Rockall and George Bligh Wedges appears to be marked by a distinct aggradational package, similar to the East Rockall Wedge (Figs. 3a,b and 6a,c).

The basinward (distal) termination of the wedges varies from abrupt to lateral transition with basinal deposits. The East Rockall, NW Rockall, George Bligh, Sandarro and East Lyonesse wedges have all suffered mass failure at their distal edge, which is commonly marked by a distinct scarp, and is most extreme along the western flank of the Rockall Basin (Figs. 3a, 5, 6a, $c$ and $7 b$ ). The North Hatton Wedge also appears to have undergone some failure, and hummocky, mounded deposits are preserved at the toe of the wedge (Fig. 7d): not to be confused with the overlying and onlapping, Neogene, mounded contourite deposits that onlap reflector C30 (Fig. 7c, d). The West Rockall (Fig. 6b), Central Hatton (Fig. 7c) and Swithin wedges display lateral continuity with the basinal deposits of the Hatton Basin, though the reflection character of the latter varies from slightly chaotic to layered. Significantly, these wedges are buried (locally onlapped) by younger Eocene basinal sediments, and on the 
Hatton High, the relationship between the Central Hatton and the younger North Hatton wedges is very clear (Fig. 7c).

The base of several wedges, notably the George Bligh and East Lyonesse wedges, and possibly the NW Rockall Wedge, appears to be an intercalation of sedimentary packages and strata marked by high-amplitude reflections (Figs. 6a, c and 7a). This relationship is similar to that described for the East Rockall Wedge, from which borehole 94/3 proved an interbedded sequence of volcanic (pillow lavas) and sedimentary rocks (Fig. 3a, b).

In section 2, it was demonstrated that the East Rockall Wedge had undergone syndepositional tilting, as well as major basinward tilting associated with Late Eocene sagging of the adjacent Rockall Basin. Late to post-depositional tilting of several other wedges is also apparent from their stratigraphic disposition, including the NW Rockall and George Bligh wedges, where the present-day sea bed dips toward the Rockall Basin, as well as the Central Hatton and West Rockall wedges, which have undergone tilting and/or sagging along with the rest of the pre-Neogene basin infill (Figs. 6 and 7a,c). The most extreme example of tilting (up to $2.4^{\circ}$ ) is associated with the North Hatton Wedge, particularly along the northern part of the Hatton High, where it is located just east of the axial crest of the North Hatton Anticline that forms the High (Figs. 5 and 7d). This anticline has an amplitude of about 1.9 $\mathrm{km}$ at the stratigraphical level of the Top Paleocene lavas, and a wavelength of about $40 \mathrm{~km}$ (Johnson et al., 2005). The overlying Eocene succession is also deformed, with the youngest horizon to be significantly folded being the Late Eocene unconformity (C30), which incorporates the top of the North Hatton Wedge.

\subsection{BGS borehole record}


Three of the prograding sediment wedges have been sampled in BGS boreholes: boreholes 94/2 and 94/3 on the East Rockall Wedge; borehole 94/6 on the NW Rockall Wedge; and borehole 94/7 on the George Bligh Wedge. In addition to the detailed description of borehole $94 / 3$ presented in section 2.1, a description of the cores recovered in boreholes 94/2, 94/6 and 94/7 is summarised in Table 6 and Figure 8.

Borehole 94/2 is located at the south-western feather-edge of the East Rockall Wedge (Fig. 2). The borehole proved a predominance of coarse siliciclastic sediment, including tuffaceous material, albeit with a thin calcilutite bed at the base of the section overlying basalt lavas and tuff. Biostratigraphic data (Stoker, 1995a) revealed a broad two-fold sedimentary subdivision: the oldest sediments at this site, including the calcilutite bed and tuffaceous sandstones, correlate with biozone NP14 (late Ypresian-early Lutetian). These are unconformably overlain by conglomerate and pebbly sandstone that ranges from NP16-18 (late Lutetianearly Priabonian). It should be noted that the lower part of the Eocene section penetrated by borehole $94 / 3$ was not present at this site, though seismic data indicate that it is probably present to the west of the site (Stoker, 1995a). The erosional boundary separating the two packages in 94/2 spans the NP15 biozone, which is consistent with the major hiatus separating units 3 and 2 in borehole 94/3 (Fig. 4).

Borehole 94/6 tested the south-eastern feather-edge of the NW Rockall Wedge (Fig. 2), and recovered Middle Eocene sandstone, correlating to biozone NP14-15, unconformably overlying basalt lava. A much thicker Eocene succession is known to be preserved to the NW of the borehole site (Fig. 6a), though there is no direct seismic tie between these areas. Thus, the total age range of the Eocene succession associated with this wedge remains unknown. 
Borehole 94/7 cored the north-western feather-edge of the George Bligh Wedge (Fig. 2), and recovered Middle to Upper Eocene limestone (NP15-18) from the aggradational, uppermost package of the sediment wedge that directly overlies basalt (Fig. 6c). A thin sand and cobble lag separates the limestone from the basalt. None of the intervening prograding sediment packages were tested. Again, the total age range of the Eocene succession associated with this wedge is unknown, though BGS short cores proved Upper Paleocene-Lower Eocene sediments (NP6-9) in the lower part of the wedge (Stoker, 1995b).

Although boreholes 94/2 and 94/6 did not penetrate the full extent of the East and NW Rockall wedges, respectively, they, together with borehole 94/3 indicate that a major MidEocene hiatus exists within the wedges on the Rockall High (Fig. 8). Whether or not this also exists on the George Bligh High remains untested. However, it is of interest to note that the uppermost aggradational package is, in common with unit 2 of the East Rockall Wedge, of Mid- to Late Eocene age, though the carbonate dominated upper section of the George Bligh Wedge contrasts with the siliciclastic lithofacies in the equivalent packages on the Rockall High.

\subsection{Relative chronology}

On the basis of the seismic stratigraphy and the borehole data, a relative correlation between the sediment wedges is proposed in Figure 9. The placement of the depositional phases within a chronostratigraphical framework is highly tentative, and is based primarily on the borehole 94/3 record for the East Rockall Wedge, albeit supported by boreholes 94/2, 94/6 and 94/7. The data from these boreholes imply a degree of consistency in wedge 
development, at least for the Rockall High and the George Bligh High. Greater uncertainty surrounds the chronostratigraphical placement of the wedges associated with the igneous centres on the flanks of the Hatton Basin, and those on the Hatton High. The seismic stratigraphy clearly indicates that the North Hatton, Lyonesse and Sandarro wedges are all younger than the Central Hatton and East Lyonesse wedges and thus, wherever they are placed in Figure 8, there cannot be any overlap between them. Whether or not the North Hatton, Lyonesse and Sandarro wedges are of Mid- or Late Eocene in age remains to be proved by future sampling.

Using the preliminary framework in Figure 9, a series of timeslice maps has been constructed in Figure 10 as a first attempt to show both the temporal and spatial development of the Eocene wedges on the Rockall Plateau. Four main conclusions can be drawn from these reconstructions:

1. The development and growth of the prograding sediment wedges persisted, albeit in an episodic manner, throughout the Eocene. Thus, a large part of the Rockall Plateau remained at or close to sea level during this time interval.

2. The main phase of sediment wedge development most likely occurred prior to the MidEocene (mid-Lutetian) hiatus.

3. Regardless of its chronological placement, it is clear that the North Hatton Wedge on the Hatton High is a late-stage feature that can only have been derived from the High itself. The most obvious scenario is that its development is linked to the early stage of uplift of the Hatton High, but was subsequently tilted during the main phase of folding associated with the formation of the North Hatton Anticline. 
4. The present structural disposition of the sediment wedges relative to one another, as well as present-day sea level, is largely a function of the differential uplift and subsidence that has affected this part of the NW British ocean margin since the Late Eocene.

\section{Conjugate NE Atlantic margin sections}

The drilled Eocene section on the Rockall High (NE Rockall margin) is here compared with equivalent sections proved elsewhere on the NW European margin, including the SW Rockall Plateau and the Faroe-Shetland Basin, together with the conjugate SE-East Greenland margin. The SW Rockall Plateau has been tested at DSDP sites, whereas the succession in the Faroe-Shetland Basin is based on BGS borehole and commercial well data. In East Greenland, we include onshore data from the Kangerlussuaq-Blosseville Kyst region, as well as ODP sites from the SE Greenland Shelf and Rise. The relevant boreholes, wells and onshore locations that form the basis for the composite sections for each area are indicated in Figure 1, and a stratigraphic-range chart for the Eocene succession across these conjugate margins is presented in Figure 11. A brief summary of the SW Rockall Plateau, FaroeShetland Basin and SE-East Greenland areas is presented below, followed by a consideration of the potential regional implications of the combined datasets, including the Rockall High.

\subsection{SW Rockall Plateau}

The Eocene succession on the SW Rockall Plateau has been tested at eight DSDP sites: 403, 404, 405, 406, 552, 553, 554 and 555 (Fig. 1). All of these sites, except 555, currently lie below 2,300 m water depth; however, in the Early Eocene, fluctuating coastal and shallowmarine environments prevailed at most sites, although a deeper marine setting may already 
have existed at sites 405 and 406 on the southern margin of the plateau (Montadert et al., 1979; Berggren and Schnitker, 1983; Roberts et al., 1984; Bull and Masson, 1996). The Lower Eocene succession in these boreholes commonly includes sandstone and mudstone with interbedded tuff. Immediately prior to rifting, the siliciclastic component was partly sourced from SE Greenland, but this provenance disappeared as the early ocean basin began to widen (Morton, 1984). During the Mid-Eocene, the SW Rockall Plateau began to subside and siliciclastic material was replaced by carbonate deposits. Nevertheless, explosive pyroclastic volcanism persisted until the end of the Mid-Eocene (biozone NP16). Two major breaks in deposition are evident from an assessment of all of the boreholes, correlating broadly with biozones NP14-15 (not at site 552) (latest Ypresian-Lutetian) and NP17 (Bartonian-earliest Priabonian), respectively (Fig. 11). It should also be noted that the Lower Eocene succession is fragmentary at all sites (except 552) within the NP11-14 interval (Ypresian-early Lutetian).

\subsection{Faroe-Shetland Basin}

In the Faroe-Shetland Basin, BGS borehole 99/3 was sited to test the Eocene succession in the area of the Judd Anticline, a major compressional structure at the SW end of the basin, where a number of distinct intra-Eocene unconformities are observed on seismic profile data (Hitchen, 1999; Smallwood, 2004; Stoker and Varming, 2011). This borehole, together with the nearby well 204/22-1, indicates that sandstone, mudstone and lignite accumulated in a deltaic setting immediately following plate breakup, and persisting until biozone NP12 (midYpresian). In borehole 99/3, the overlying section comprises base-of-slope marine mudstone of NP14-15 (Lutetian) age, though seismic data indicate that an intervening package of sediment is preserved to the NW of the borehole site, and this has been tentatively assigned a 
late Ypresian age ( NP13) (Stoker and Varming, 2011). The uppermost unit in borehole 99/3 comprises lower-slope marine mudstone of Priabonian age. These data imply a major hiatus at this site between NP15 and NP18 (mid-Lutetian-Priabonian).

\subsection{SE-East Greenland margin (onshore and offshore)}

Onshore central east Greenland preserves a record of a prolonged history of post-breakup magmatism (Tegner et al., 1998, 2008). Immediately south of Kangerlussuaq (Fig. 1), there were two main magmatic pulses: 1) the emplacement of basic gabbros, dykes and lavas at 50-47 Ma; and 2) the emplacement of alkaline plutons at 37-35 Ma. In contrast, north of Kangerlussuaq basic and alkaline intrusions spanning 52-36 Ma occur in the Blosseville Kyst region. The latter region also preserves sediments of late Early to Mid-Eocene age in the Kap Dalton and Savoia Halvø areas. These deposits include reworked fluvial conglomerates, upper shoreface sandstones, shallow-marine siltstone and mudstone, and rare paralic coal, which are dated at Kap Dalton as Mid-Eocene (Lutetian, NP14-15) (Larsen et al., 2005) (Fig. 11). Volcaniclastic material forms a major component of the sediments, though the upper shoreface deposits are quartz-rich. The section is interpreted to have been deposited during an overall rise in sea level; however, the upper shoreface deposits and the coal bed represent brief intermittent periods of sea level fall.

On the SE Greenland Shelf and Rise, ODP sites 914-918 proved a punctuated succession of Lower to Upper Eocene red mudstone, volcaniclastic siltstone, siltstone, nannofossil claystone and chalk, which were deposited in fluviatile, marginal marine (including lagoonal) and shelf environments (Shipboard Scientific Party, 1994a; Saunders et al., 1998). Sites 915, 916 and 918 all record an unconformity-bounded package of sediment deposited during 
biozone NP12 (Ypresian) (Fig. 11). A hiatus exists between NP12 and NP16 in the current shelf sites (915-917: 500 m water depth). In contrast, deposition at site 918, presently on the continental rise (1868 m water depth), ranges across the NP13-16 biozones (late Ypresianearly Bartonian), indicating general subsidence of this part of the margin, concomitant with the formation of the Irminger Basin (Shipboard Scientific Party, 1994b). Sites 917 and 918 do not preserve Eocene sediments younger than NP16 in age; however, Middle to Upper Eocene sediment at site 915 spans the NP16-20 (late Lutetian-Priabonian) biozones. Upper Eocene deposits are also present at site 914. Collectively, the shelf data suggest at least one major hiatus at around NP15-16 time.

\subsection{Regional implications}

On the basis of the above data, we are able to make some general regional observations concerning the Eocene post-rift development of the conjugate continental margins, in terms of palaeogeography, post-rift volcanism, and regionally correlatable unconformities.

\subsubsection{Palaeogeography}

A marginal marine to shallow marine depositional environment prevailed in all of the study areas throughout the Early Eocene, and persisted on the Rockall High and in most of the SEEast Greenland region throughout the Mid- and Late Eocene. Although the SW Rockall Plateau, Faroe-Shetland Basin and SE Greenland margin (at site 918) began to subside during the Mid-Eocene, the accumulation of tuffaceous material on the SW Rockall Plateau into the late Mid-Eocene implies the proximity of adjacent land areas. This is consistent with other regional evidence from the Rockall region that suggests that some of the more isolated banks 
or former seamounts remained close to contemporary sea level during Mid- to Late Eocene time: e.g. the bioclastic limestone recovered in BGS borehole 94/7 on the top of George Bligh High (Fig. 8), and a nearshore volcanic conglomerate from the top of Anton Dohrn seamount (Stoker, 1997).

\subsubsection{Post-rift magmatism}

The initiation of seafloor spreading between Greenland and NW Europe is generally regarded to have occurred at about 56-54 Ma, during chron C24r (Early Eocene, Ypresian) (Saunders et al., 1997). In the Faroe Islands, it is dated as 54.5-54.8 Ma (Passey and Jolley, 2009). Whereas syn-rift magmatism was prevalent in the SE-East Greenland, Rockall-Hatton and Faroe-Shetland regions (Saunders et al. 1997; Larsen et al. 1999; Ritchie et al. 1999; Jolley and Bell 2002), subsequent igneous activity is assumed to have been largely restricted to the NE-trending spreading ridges (e.g. Mid-Atlantic and Aegir ridges). Inspection of Figure 11, however, indicates that magmatic activity, albeit less extensive, persisted regionally on the conjugate margins for up to $7 \mathrm{My}$, at least, after breakup, and more locally (e.g. SW Rockall Plateau, central East Greenland) for between 12 and $20 \mathrm{My}$. In the East Greenland region, the prolonged magmatism has been linked to the reconfiguration of the spreading ridges in the NE Atlantic, including the protracted rift-to-drift transition associated with the Jan Mayen micro-continent (Tegner et al., 2008; Gaina et al., 2009)

\subsubsection{Regional unconformities}

Notwithstanding issues of biostratigraphic resolution, there is at least one major hiatus that appears to be recorded across the region, herein referred to as the mid-Lutetian unconformity. 
From Figure 11, this probably correlates with the NP15/16 biozone and chron C20. Although the Lower Eocene record is quite fragmentary, two further hiatuses might be significant: of mid-Ypresian (NP12) and late Ypresian (NP13) age. Both of these are well constrained in the Rockall High and Faroe-Shetland Basin regions, whereas the latter is also observed on the SE Greenland margin.

\section{Evolution of the Eocene ocean crust}

In sections 2-4 we have focused on the Eocene record of early post-rift sedimentation on the continental margins bordering the southern part of the newly-developed NE Atlantic Ocean. On the Rockall Plateau, key observations include: 1) the punctuated growth of numerous prograding wedges across the margin during Early to early Mid-Eocene times, accompanied by sporadic post-breakup volcanism; 2) a switch-off in the main phase of plateau-wide prograding wedge development in the Mid-Eocene; and, 3) Late Eocene growth and deformation of discrete prograding wedges on the outermost margin. In order to try and understand this record of change, and what it might mean in terms of the driving forces active in early margin development, this section employs geophysical data from the adjacent ocean crust in order to assess any potential linkage between the growth of the young ocean basin and the evolution of its margins. The combination of the biostratigraphy data from borehole $94 / 3$ and the magnetostratigraphic record of the ocean crust provides a method for correlating pulses of continental margin sedimentation relative to changes in the development of the ocean basin.

Gravity images reveal distinct patterns over the Atlantic oceanic crust (Fig. 12a). The earliest ocean crust, adjacent to the continent-ocean boundary (COB), is characterised by a relatively 
smooth gravity field. More disturbed gravity anomalies with an ESE trend characterise a zone where the oceanic crust has been segmented by fracture zones in the region beyond about 200 $\mathrm{km}$ from the COB and $300 \mathrm{~km}$ from Iceland. Further to the NW the gravity anomaly pattern becomes smoother again but contains $\mathrm{V}$-shaped ridges - clear gravity and bathymetric lineations centred on the Reykjanes Ridge and converging in a south-westward direction. These features have been interpreted to be caused by crustal thickness variations associated with pulses of relatively hot asthenosphere which have flowed south-westward beneath the mid-ocean ridge from a source beneath Iceland and at a velocity that can be estimated from their geometry (Vogt, 1971; White et al., 1995).

The same evolution from smooth to segmented crust and then to $\mathrm{V}$-shaped ridges can be recognised on the NW side of the Atlantic (e.g. Jones, 2003, his fig. 1), and this provides strong evidence that the changes are in response to conditions at the time the crust was formed at the mid-ocean ridge. These characteristics are 'frozen' into the crust in an analogous fashion to the acquisition of remanent magnetisation, and comparison with magnetic anomaly data (Fig. 12b) allows the chronology of the different crustal types to be calibrated. The onset of fracturing parallels the oceanic magnetic anomalies and thus appears to be synchronous along this margin. It first appears at around magnetic chron $\mathrm{C} 18 \mathrm{~N}$ (c. 39 Ma) but the signatures become more marked about 5 Ma later (dashed lines 3 and 4 in Fig. 12). The change from segmented crust to $\mathrm{V}$-shaped ridges is diachronous, occurring later at points more distant from Iceland (dashed line 5 in Fig. 12). The earliest of the ridges visible on the eastern side of the Reykjanes Ridge appears to have been initiated beneath Iceland during Miocene times (Wright and Miller, 1996; Jones et al., 2002). Jones et al. (2002) note that there is evidence for earlier (Oligocene) V-shaped ridges on the western side of the 
Reykjanes Ridge, which may be visible because the sedimentary cover (which attenuates the associated gravity signal) is thinner on that side.

The calibration of the oceanic crust can be further refined using seismic reflection data, and in particular the long transects recorded in 1999 by the National Oceanography Centre (NOC; Elliott and Parson, 2008). Smooth oceanic basement adjacent to the COB and fractured oceanic basement further NW can be correlated with the gravity signatures identified above, but the seismic data also indicate a zone with distinct properties (the transitional oceanic basement of Elliott and Parson, 2008) which lies between these two domains. The basement reflector is less smooth and less well-imaged in this transitional zone than it is further SE but the contrast is too subtle and deeply-buried to be resolved by gravity data. Our interpretation of the boundary between the smooth and transitional basement (dashed line 2 in Fig. 12) is that it lies parallel to and just inboard of the positive magnetic anomaly associated with chron C21N (at around $48 \mathrm{Ma}$ ), although Elliot and Parson (2008) indicate a somewhat more sinuous course.

There is geophysical evidence for post-breakup magmatism in this area. Elliott and Parson (2008) interpret Endymion Spur, a distinct margin-parallel topographic feature, to be a chain of volcanic centres erupted through the earliest oceanic crust. Multibeam bathymetric images provide evidence of volcanic cones (Elliot and Parson, 2008) and the NOC seismic reflection data also indicate apparent intrusions that disrupt the oceanic basement reflector but no longer form a topographic feature at the seabed because of blanketing by sediment. The youngest such feature that has been identified lies close to chron $\mathrm{C} 21 \mathrm{~N}$, about $25 \mathrm{~km}$ west of a similar feature published in Elliot and Parson (2008: their Fig. 7a). This is consistent with the post-breakup volcanism recorded in the BGS boreholes on the Rockall High, as well as 
more regional evidence, e.g. the Traill-Vøring igneous complex that cuts across anomalies C24A-23 and C22 on the Vøring and East Greenland margins, respectively, flanking the Norwegian-Greenland Sea (Olesen et al., 2007).

The gravity model of Kimbell et al. $(2004,2005)$ reveals clear variations in the thickness of the oceanic crust in this area (Fig. 13). Thick oceanic crust has been generated beneath the Iceland-Faroe Ridge (IFR) from breakup until the present day, probably reflecting the continuing influence of relatively high mantle potential temperatures associated with the Iceland hotspot. The part of the IFR formed immediately following breakup is broad; there is then a gradual decrease in width to a minimum at about anomaly $\mathrm{C} 20 \mathrm{~N}$ time (42 Ma) before an increase again toward the present-day broad feature (Fig. 13). Although later processes (e.g. flow of lavas across older oceanic crust) may have had an influence, the underlying pattern has been interpreted to indicate temporal variation in hotspot influence, either because of changes in asthenosphere temperature and/or convection rate or because of changes in the position of the mid-ocean ridge with respect to the hotspot (Kimbell et al., 2005).

The magnetic anomaly pattern within about $500 \mathrm{~km}$ of the axis of the IFR is enigmatic. This is in part because of poor magnetic survey coverage, but even with further survey data there are likely to be problems in identifying oceanic magnetic anomalies in the parts of this area where the enhanced magmatism led to emplacement into a subaerial environment (anomaly continuity is much clearer in oceanic crust formed under submarine conditions). A landward step in the $\mathrm{COB}$ in this area can be correlated with a conjugate oceanward step on the Greenland margin, suggesting the presence of a transform offset (Featherstone et al., 1977; Smallwood and White, 2002) which may have been inherited from the Anton Dohrn continental lineament (Kimbell et al., 2005). Any transform offset had disappeared by the 
time of chron C21N, which is associated with a continuous magnetic anomaly (Fig. 12b), suggesting that the offset was removed as a result of ridge-jump. It is, however, not easy to identify a fossil ridge from the available data and it is possible that the change was effected by a series of small ridge-jumps (Kimbell et al., 2005) or a diffuse spreading system (Elliott and Parson, 2008).

In the area more than about $500 \mathrm{~km}$ from the axis of the IFR, the gravity model (Fig. 13) indicates a pattern that is broadly compatible with the results of seismic experiments (e.g. Barton and White, 1997; Parkin and White, 2008). The wide-angle seismic model for the iSIMM (integrated Seismic Imaging and Modelling of Margins) Hatton profile (location shown in Fig. 13) indicates igneous oceanic crust decreasing in thickness from 15-16 km adjacent to the continent-ocean boundary to $10 \mathrm{~km}$ at a point $65 \mathrm{~km}$ to the $\mathrm{NW}$, where there is a sharp inflection to a more gradual oceanward reduction in crustal thickness (Parkin and White, 2008; White and Smith, 2009). The gravity model contains a comparable inflection. On the iSIMM line it coincides with the boundary at chron $\mathrm{C} 21$ between smooth and transitional oceanic basement identified from seismic reflection data (dashed line 2 in Fig. 13), but an apparent divergence between these features further SW suggests that this may be circumstantial. There is limited seismic information on the thickness of the segmented oceanic crust; comparison with the $8 \mathrm{~km}$ thickness interpreted at the NW end of the iSIMM profile (Parkin and White, 2008) suggests that the gravity model may overestimate crustal thickness by about $2 \mathrm{~km}$ in this area. Closer to the Reykjanes Ridge, the crust affected by Vshaped ridges appears to be characterised by thicknesses of about $10 \mathrm{~km}$ at the ridges and 8 $\mathrm{km}$ at the troughs between them (Smallwood and White, 1998). 
The formation of unfractured early oceanic crust suggests that the lithosphere was behaving in a ductile fashion at that time. This may have been due to a combination of factors: (i) the higher mantle temperatures associated with the generation of thickened oceanic crust; (ii) the more frequent injections of melt required to produce this thickening; (iii) the influence of this thickened, thermally insulating layer on the mantle geotherm (White, 1997); and, (iv) a faster spreading rate (Gaina et al., 2009; Whittaker et al., 2008). The change from smooth oceanic basement to transitional basement just before chron $\mathrm{C} 21 \mathrm{~N}$ does not correspond exactly with the minimum in the width of the IFR at about chron C20N. More seismic data are required to track the basement change towards the IFR and assess whether it follows a diachronous course (in which case it might be explained by temperature-related rheology) or follows an isochron (in which case an additional factor needs to be sought). In the latter case, there may be a connection with a change in spreading rate and direction inferred by Gaina et al. (2009) and with the 'ironing out' of the mid-ocean ridge offset that appears to have occurred at this time.

The requirement for an additional factor in the development of segmented crust after chron $\mathrm{C} 18 \mathrm{~N}$ is clear, as this occurred simultaneously along the margin some time after the end of the rapid decline in magma production. This factor is likely to be the change from an orthogonal to an oblique ocean spreading direction. Where the lithosphere is strong, oblique spreading is accommodated by a series of short ridge segments which are perpendicular to the spreading direction, offset in a stepwise manner and separated by fracture zones which parallel the spreading direction (Jones, 2003). The change in spreading geometry resulted from plate reorganisation, which involved the cessation of spreading in the Labrador Sea and transfer of spreading from the Aegir Ridge to the Kolbeinsey Ridge in the Norwegian Sea (Lundin and Doré, 2002, 2005; Jones, 2003). The main phase of reorganisation is generally 
regarded to have occurred at around chron $\mathrm{C} 13$, which does coincide with the observed onset of pronounced fracturing at c. $34 \mathrm{Ma}$. However, the fact that some fracturing appears to have been initiated earlier (C18N; c. $39 \mathrm{Ma})$ suggests an earlier initiation for the changes in spreading geometry, and there is support for this in the flowlines of Smallwood and White (2002) and Gaina et al. (2009).

The replacement of fractured oceanic crust by smoother crust with V-shaped ridges occurred where the lithosphere had become weak enough to accommodate oblique spreading in a ductile fashion rather than by brittle fracturing. This change is primarily temperature-related (there is no evidence of a change in spreading obliquity at this time), and its diachronous nature has been linked by Jones (2003) to the westward movement of the Reykjanes Ridge over the centre of the Iceland hot-spot.

A tentative chronology of Eocene ocean crust development can be defined on the basis of these observations:

c. 55-48 Ma Breakup, followed by a period of declining magmatic production in areas away from the axis of the IFR; the oceanic basement is characteristically smooth; ridge jumps or diffuse spreading in the area immediately to the SW of the IFR.

c. $48 \mathrm{Ma}$ Cessation of the rapid decline in crustal thickness on the Hatton margin; change to less smooth oceanic basement; no longer an offset in the midocean ridge after this time; intrusion of youngest seamounts?

c. $43 \mathrm{Ma}$ A minimum in the influence of the Iceland hotspot is suggested by the 'neck' in the IFR. 
c. $39 \mathrm{Ma} \quad$ Initiation of fracturing in oceanic crust (onset of plate reorganisation?)

c. $34 \mathrm{Ma} \quad$ Highly segmented oceanic crust being formed (oblique spreading wellestablished)

Post-Eocene Initiation of V-shaped ridges.

\section{Discussion}

This paper has presented a set of observations that detail aspects of Eocene stratigraphy, sedimentation and volcanism on the Rockall Plateau. Integration of these observations with oceanic crustal information from the adjacent Iceland Basin has resulted in the development of an Eocene tectonostratigraphic framework for this ocean margin (Fig. 14), which is summarised below. In addition, the recognition of potentially synchronous unconformities on the conjugate margins of NW Britain/Rockall/Ireland and SE Greenland has prompted a tentative correlation with eustatic sea level and oxygen isotope curves (Fig. 15) in a bid to better understand regional controls on Eocene sedimentation during the early history of the ocean basin.

\subsection{Eocene tectonostratigraphy of the Rockall Plateau}

At least two main phases of Eocene prograding clastic sediment wedges are preserved on the Rockall Plateau: 1) a Ypresian to early Lutetian phase of subaqueous fan-delta development and contemporary volcanism, especially well calibrated by borehole 94/3 on the East Rockall Wedge; and, 2) a late Lutetian to Priabonian (?) phase of sedimentation that is probably best developed on the Hatton High - in particular the North Hatton Wedge - though shallow- 
marine sedimentation persisted on the Rockall High and George Bligh High. These two phases are summarised below.

\subsubsection{Phase 1: Ypresian-early Lutetian segmented/transform margin}

On the basis of the evidence from borehole 94/3, the development of the Ypresian-early Lutetian subaqueous fan-deltas was probably episodic and interspersed with subaerial exposure and volcanic activity (Fig. 3c). The East Rockall Wedge shows evidence of synsedimentary tilting, whereas the evolving heavy mineral assemblage (reflecting unroofing of igneous bodies) (Table 3) suggests that the Rockall High was being generally uplifted. The switch-off in the main development of the subaqueous fan-delta of the East Rockall Wedge occurred during early Lutetian times, corresponding with chron C21 (Fig. 14). It may be no coincidence that this appears to correlate with a number of changes in the nature of the adjacent oceanic crust at this time, including: 1) a change from smooth to transitional (rougher) oceanic basement, possibly associated with a reduction in spreading rate; 2) 'Ironing out' of ridge offsets - chron C21 is the first unbroken anomaly along the entire length of the Rockall margin, whereas pre-chron C21 seafloor anomalies are offset adjacent to the northern end of the Hatton High, where the anomaly pattern is also generally more diffuse; and, 3) a cessation in the rapid decline of crustal thickness on the Hatton margin (Fig. 13). In terms of crustal evolution, the implications of these changes remain unclear; however, their overall significance is that they mark the point at which the spreading history of the ocean basin essentially adopted the pattern that we see at the present-day. Arguably, this represents the rift-to-drift transition, manifested by the change from a segmented/transform margin (phase 1, this section) to an unsegmented, continuously spreading, margin (phase 2; 
section 6.2.1). Additionally, Gaina et al (2009) report a change in the direction of plate motion of Greenland relative to Eurasia at chron C22/C21 time.

The segmented nature of the Rockall continental margin is evident in Figures 12 and 13, where the continent-ocean boundary is clearly offset at a number of locations (Kimbell et al., 2005; Elliott and Parson, 2008). The segments are inferred to be bounded by deep crustal lineaments trending orthogonal to the margin. The Anton Dohrn Lineament is the best known structure, and has been interpreted to have been active as a Mesozoic transfer zone, which provided the structural offset subsequently adopted by the line of breakup (Kimbell et al., 2005). Elliott and Parson (2008) describe significant along-strike variation in tectonomagmatic facies across the segmented blocks, and have thus invoked segmentation as a major control on the structural and volcanic evolution of the ocean margin. The development of the contemporary subaqueous fan-deltas may also be a response to margin segmentation. It is not inconceivable that episodic pulses of sedimentation interspersed with uplift and volcanism are responses to plate boundary stresses generated along the segmented margin, and transmitted along the orthogonal lineaments up to $400 \mathrm{~km}$ into the margin. Fast spreading rates over the chron $\mathrm{C} 24-\mathrm{C} 22$ interval and a change in spreading direction during chron C22 (Gaina et al., 2009) may have contributed to the tectonic forces that were active in this region during the early phase of sea-floor spreading.

Elliott and Parson (2008) further suggest that segmentation may have contributed to the compartmentalisation of melt production and channelisation along the ocean margin, e.g. presence or absence of volcanic dipping reflectors. This might be associated with patterns of small-scale convection superimposed on the regional influence of a mantle thermal anomaly factors to be considered when attempting to explain both the variation (pyroclastics; lavas) 
and the persistence in post-rift volcanic activity across the margin, as preserved in boreholes 94/2 and 94/3, during this phase.

\subsubsection{Phase 2: Late Lutetian-Priabonian continuously spreading margin}

Lithological and seismic evidence from the Rockall High and George Bligh High indicate that shallow-marine sedimentation persisted across these features, though their shallower parts may have remained exposed. The tilting and burial of some wedges, such as the West Rockall and Central Hatton wedges that flank the Rockall and Hatton highs, suggest that some degree of flexure occurred along the flanks of the Hatton Basin. By way of contrast, the North Hatton Wedge was wholly developed in this stage, and, despite its outer margin location, was sourced from the northwest (Fig. 10d). At this point in time the Eocene ocean was probably 400-500 km wide; thus, the wedge can only have been derived from the Hatton High on which the North Hatton Wedge is located. This implies two things: 1) the outer margin was exposed and/or rejuvenated as a source area in the Mid- to Late Eocene; and, 2) the eastward tilting of the wedge is most probably a response to compressional deformation along the outer margin. The latter is associated with the growth of the North Hatton Anticline, which, according to Johnson et al. (2005), was developing from at least the MidEocene, and possibly the Early Eocene (Tuitt et al., 2011). This would therefore suggest that both the deposition and subsequent tilting of the North Hatton Wedge might reflect the progressive growth of this anticline.

It is interesting to note that in the adjacent Iceland Basin, an increase in the intensity of fracturing within the oceanic basement is recorded from about chron C18 times (Bartonian), though this signature becomes more marked about 5 Ma later (Fig. 16). In section 5 it was 
suggested that the initiation of fracturing in the oceanic crust might represent the onset of plate reorganisation, in response to a change in spreading geometry at chron C18 (Smallwood and White, 2002; Gaina et al., 2009), which culminated in chron C13 times when the change from orthogonal to oblique spreading was established. Our observations regarding the development of the later phase of prograding sediment wedges, especially the North Hatton Wedge, may represent a continental margin response to the changes in spreading direction where the growth and enhancement of the North Hatton Anticline is a direct consequence of the rearrangement of plate boundary forces. The deposition of the North Hatton Wedge may have coincided with the initiation of oblique spreading, as the North Hatton Anticline began to develop, whereas the subsequent tilting of the wedge marks the accentuation of the anticline at the end of the Eocene as the plate reorganisation was finally established. Cenozoic post-breakup compressional features are well documented in the NE Atlantic region (e.g. Doré and Lundin, 1996; Lundin and Doré, 2002; Johnson et al., 2005; Doré et al., 2008). Set against a background of near-continuous ridge-push deformation that is associated with the regional, post-breakup, compressional intraplate stress field in the NE Atlantic, it has been suggested that such periods of 'enhanced ridge-push' deformation essentially represent episodic pulses of higher strain-rate deformation that coincide with plate boundary reconfigurations (Holford et al., 2009). Other significant end-Eocene events across the Rockall region, at this time, include the rapid subsidence and deepening of the Rockall and Hatton basins (Stoker, 1997; Stoker et al., 2001; Praeg et al., 2005).

\subsection{Regional controls on Eocene ocean-margin sedimentation}

Inspection of Figure 11 reveals a number of intra-Eocene unconformities between the FaroeShetland, Rockall and SE-East Greenland regions. The mid-Lutetian unconformity is the 
most significant unconformity with synchronous expression across all areas. In contrast, regional correlation of the intra-Ypresian unconformities is less confident; whilst there are indications of regional breaks in sedimentation, herein referred to as mid-Ypresian and late Ypresian unconfomities, the timing of the breaks is not quite as synchronous between the various regions.

In the context of a newly developing ocean basin, the most likely processes responsible for unconformity formation are probably tectonomagmatic activity and eustasy, or a combination of the two. On the basis of borehole 94/3, together with the preserved sections across the conjugate margins, the main phases of Ypresian-early Lutetian sedimentation were probably linked to $3^{\text {rd }}$ order cycles, which typically have durations of 1 to $5 \mathrm{Ma}$ (Fulthorpe, 1991) (Figs. 11 and 14). In terms of tectonomagmatic processes, intraplate stresses and short-term $\left(10^{6} / 10^{7} \mathrm{yrs}\right)$ thermal anomaly fluctuations are commonly cited as potential factors in $3^{\text {rd }}$ order cyclicity linked to sedimentation and sea-level change (Cloetingh, 1988; White and Lovell, 1997; Smallwood and White, 2002). An association between plate boundary deformation and changes in spreading direction in chrons C22 and C21 (Gaina et al., 2009) was suggested above (section 6.1) as a potential link between sedimentation and regional tectonics on the Rockall Plateau during the early post-breakup (rift-to-drift) phase, when the margin was segmented. Bearing in mind the contemporary volcanism across the region, this was accompanied by magmatic activity which would have affected the buoyancy flux, and hence uplift, of the margins. By way of contrast, superimposition of the mid- and late Ypresian unconformities on the eustatic sea level curve suggests that a correlation to, or coincidence with, major falls in global sea level cannot be discounted, especially in association with the late Ypresian unconformity (>100 m) (Fig. 15). A eustatic origin has been applied to the formation of this unconformity in East Greenland (Larsen et al., 2005). 
Parkin et al. (2007) and Parkin and White (2008) have identified a local thickening of the oceanic crust beneath the iSIMM Faroes profile which is also detected by the gravity model (Figure 13; feature A, centred at about $60 \mathrm{~km}$ from the NW end of the profile). A $1.5 \mathrm{~km}$ increase in crustal thickness was interpreted to be caused by a c. $25^{\circ} \mathrm{C}$ thermal 'pulse' in the temperature of the material which rose in the Iceland plume and spread out laterally, reaching the intersection between the mid-ocean (Aegir) ridge and this profile at 45-48 Ma (Parkin and White, 2008). The process is analogous to that which is inferred to have been responsible for the Neogene V-shaped ridges. Subsequently published aeromagnetic data (Olesen et al., 2010) reveal that the crustal thickening beneath the iSIMM Faroes profile more likely coincides with the $\mathrm{C} 23 \mathrm{~N}$ chron (51.5 Ma). The distance from the Early Eocene plume axis (as positioned by White and McKenzie, 1989) to the Faroes profile and Rockall Plateau areas would have been about $300 \mathrm{~km}$ and $500-1000 \mathrm{~km}$ respectively. It is difficult to estimate a lateral propagation velocity from the indistinct gravity indications of early $\mathrm{V}$-shaped ridges, but the more recent ridges suggest values of 200-250 km/Ma (Vogt, 1971; Jones et al., 2002). On this basis it could have taken the pulse c. 2 Ma longer to reach the Rockall Plateau, potentially coinciding with the Late Ypresian unconformity. The modelled oceanic crustal section beneath the iSIMM Hatton profile indicates a marked decrease in magmatic productivity through the Ypresian, but there is a small feature towards the end of this decline in the interpretation of Parkin and White (2008: their Fig. 10) that might be due to the superimposition of a modest thermal pulse.

Biostratigraphic data suggest that the regionally extensive mid-Lutetian unconformity was formed around the NP15/16 boundary. This also appears to correlate with a falling sea level on the eustatic curve, as well as with oxygen isotope stage Eli-4, which may indicate a 
potential glacio-eustatic component. However, the eustatic curve suggests that any fall in sea level was only tens of metres in magnitude (Fig. 15). From a tectonomagmatic perspective, the development of this widespread erosional unconformity was preceded by the change in spreading direction at chron $\mathrm{C} 21$, and coincided with the apparent minimum in the influence of the thermal anomaly in the oceanic area, as exemplified by the 'necking' of the IcelandFaroe Ridge (Fig. 13). The decreased dynamic support might have been expected to be associated with a relative rise in regional sea level rather than the inferred fall.

There is no clear evidence along the iSIMM Hatton profile (location shown in Figure 13) of a thermal pulse that could be associated with the mid-Lutetian unconformity (Parkin and White, 2008), so it appears difficult to reconcile this unconformity with a simple, radiallypropagating asthenospheric thermal anomaly. A more complex thermal explanation may, however, be possible. The geometry of the Iceland-Faroe Ridge indicates a distinct asymmetry between its NE and SW sides. The triangular zone of crustal thickening on the SW side of the ridge (B in Figure 13) is much wider than that to the NE (A), but both follow a similar decrease towards a minimum at around chron C20. The larger feature to the $\mathrm{SW}$ is due to a combination of greater magma volumes and faster spreading rate on that side, compatible with the preferential extension of the thermal anomaly into that area. It is possible that the breakdown in margin segmentation that preceded the mid-Lutetian unconformity facilitated the migration of the thermal anomaly beneath the continental area to the south. This could have led to a simultaneous increase in (or at least maintenance of) dynamic support in that area, and decrease in ridge-related magmatic activity.

From the foregoing discussion it seems most likely that the preserved Eocene rock record on the Rockall Plateau and adjacent margins is a natural response to a combination of processes, 
including intraplate stress, variation in the convection of the developing Iceland hotspot, and eustasy. The key question is: of these processes, what was the major driving force? On the basis of our study, the following observations suggest that plate reorganisation and associated boundary forces may have predominated: 1) the late Ypresian, mid-Lutetian and Late Eocene unconformities were all preceded by a change in spreading direction; and, 2) the growth and tilting of the North Hatton wedge is intimately linked to compression and the formation of the North Hatton anticline. The role of mantle thermal anomalies in the development of the unconformities, and the nature of any interaction between tectonic and thermal processes, are difficult to judge on current evidence. The fact that thermal anomalies take time to migrate across a region opens up the possibility of using detailed (in time) but widely distributed (geographically) tectonostratigraphic studies to test for their influence. For example, the synchroneity of the mid-Lutetian unconformity across the conjugate margin (Fig. 11) would appear to make a thermal explanation more difficult to sustain.

On a higher order, it might be considered that the two main stages of margin development segmented/transform to continuous spreading - represent $2^{\text {nd }}$ order cycles (10-30 My), where the switch-off of widespread fan-delta development to more localised accumulations (along the Hatton High), and then to outer margin compression is a response to regional changes in the structure of the ocean crust (e.g. Smallwood and White, 2002), albeit linked to plate reorganisation (cf. Gaina et al., 2009); essentially the change from smooth to fractured crust between chron $\mathrm{C} 24$ and $\mathrm{C} 13$ times. The mid-Lutetian unconformity separates these two cycles, whereas the Late Eocene unconformity (Stoker et al., 2001) represents the major plate reorganisation event that culminated at chron $\mathrm{C} 13$. The $3^{\text {rd }}$ order cycles of sedimentation and sea-level change would thus be superimposed on these $2^{\text {nd }}$ order cycles. 
In the broader context of the Cenozoic post-rift development of the NW European Atlantic margin, these major Eocene unconformities form part of a series of regional deformation events that have been described from this passive margin. Widespread compressional deformation in Early/Mid-Miocene times and large-amplitude tilting of the margin during Early Pliocene times produced tectonic unconformities that are widely recognised within the sedimentary succession of the NW European Atlantic margin (Doré et al., 1999; Praeg et al., 2005; Stoker et al., 2005a; Holford et al., 2009). Moreover, significant exhumation episodes linked to these deformation phases have driven changes in regional sedimentation patterns (Green et al., 2002; Holford et al., 2009, 2010; Stoker et al., 2010). It may be no coincidence that the Eocene and the Neogene deformation phases correlate closely with changes in plate tectonic motions in the NE Atlantic region, which may imply a causative link between plate boundary forces and passive margin/intraplate tectonic activity throughout the post-rift period.

\section{Conclusions}

An Eocene tectonostratigraphic framework developed for the Rockall Plateau shows that the sedimentary succession is interspersed with several unconformities, interpreted to record sedimentary responses to regional tectonic, magmatic and eustatic events. In particular:

- In the Early to early Mid-Eocene, a major phase of prograding sediment wedge development (subaqueous fan-deltas, e.g. East Rockall Wedge) took place across the Rockall Plateau, during an interval when it was segmented and offset along crustal lineaments, such as the Anton Dohrn Lineament. This phase of wedge development was terminated in the Lutetian when the segmented/transform 
margin was replaced by a continuously spreading margin - the rift-to-drift transition - during chron C21. Margin segmentation, possibly linked to patterns of small-scale convection, may have also played a role in the persistence and variation in the anomalous post-rift volcanism.

- In the Mid-/Late Eocene, a later development of prograding sediment wedges was restricted to the outer margin (e.g. North Hatton Wedge); a response to Midto Late Eocene compression along the ocean margin that culminated towards the end of the Eocene, possibly during a phase of enhanced ridge-push, with the formation of the North Hatton Anticline, and the concomitant deformation of the associated wedges. Rapid subsidence of the Rockall Basin and partial collapse of the fringing earlier Eocene wedges also occurred at this time.

- A series of intra-Eocene unconformities, of which the mid-Lutetian unconformity is best developed, have been traced across the conjugate margins bordering the early ocean basin. There appears to be some correlation with $3^{\text {rd }}$ order changes in eustatic sea level; however, tectonomagmatic processes related to the rift-to-drift transition, changes in spreading directions between Greenland and Eurasia, and mantle thermal perturbations cannot be discounted. Further work is clearly necessary to better understand the controls on these intra-Eocene unconformities.

- Arguably, the two main phases of Eocene sedimentation (Early-early MidEocene and Mid-/Late Eocene) represent $2^{\text {nd }}$ order sedimentary cycles; a response to regional changes in oceanic structure associated with the rift-to-drift transition, and plate reorganisation from orthogonal to oblique spreading, respectively. 


\section{Acknowledgements}

We thank H. Johnson and K. Hitchen for their support of this project, and for comments on an earlier version of this manuscript. We are also grateful to the following oil companies who, together with the BGS, make up the Rockall Consortium, and without whose support this work could not have been undertaken: ENI, Shell and Statoil, together with DECC (Department of Energy and Climate Change). Thanks are also due to Simon Holford, and an unnamed referee, as well as the associate editor, Paul Mann, for critical reviews that greatly improved the quality of the manuscript. This paper is published with the permission of the Executive Director, BGS (NERC).

\section{References}

Abreu, V.S., Anderson, J.B., 1998. Glacial eustasy during the Cenozoic: sequence stratigraphic implications. American Association of Petroleum Geologists Bulletin, 82, 13851400.

Bannister, K., 1995. A palaeomagnetic polarity study of 7 cores from in and around the Rockall Trough. Report prepared for the BGS-Rockall Consortium (Open-File Access)

Barton, A.J., White, R.S., 1997. Crustal structure of Edoras Bank continental margin and mantle thermal anomalies beneath the North Atlantic. Journal of Geophysical Research, B102, 3109-3129.

Berggren, W.A., Schnitker, D., 1983. Cenozoic marine environments in the North Atlantic and Norwegian-Greenland Sea, in: Bott, M.H.P., Saxov, S., Talwani, M., Thiede, J. (eds), Structure and Development of the Greenland-Scotland Ridge: New Methods and Concepts. Plenum Press, New York, pp. 495-548. 
Boldreel, L.O., Andersen, M.S., 1993. Late Pliocene to Miocene compression in the FaeroesRockall area, in: Parker, J.R. (ed.), Petroleum Geology of Northwest Europe, Proceedings of the $4^{\text {th }}$ Conference. The Geological Society, London, pp. 1026-1034.

Boldreel, L.O., Andersen, M.S., 1998. Tertiary compressional structures on the FaroeRockall Plateau in relation to northeast Atlantic ridge-push and Alpine foreland stresses. Tectonophysics, 300, 13-28.

Bull, J.M., Masson, D.G., 1996. The southern margin of the Rockall Plateau: stratigraphy, Tertiary volcanism and plate tectonic evolution. Journal of the Geological Society, London, $153,601-612$

Ceramicola, S., Stoker, M.S., Praeg, D., Shannon, P.M., De Santis, L., Hoult, R., Hjelstuen, B.O., Laberg, J.S., Mathiesen, A., 2005. Anomolous Cenozoic subsidence along the 'passive' continental margin from Ireland to mid-Norway. Marine and Petroleum Geology, 22, 10451067.

Cloetingh, S., 1988. Intraplate stresses: a tectonic cause for third-order cycles in apparent sea level? In: Wilgus, C.K., Hastings, B.S., Kendal, C.G.St C., Posamentier, H.W., Rocc, C.A., Van Wagoner, J.C., (Eds), Sea-Level Changes: An Integrated Approach. Society for Economic Palaeontologists and Mineralogists, Special Publication 42, pp. 19-29.

Cobbold, P.R., Meisling, K.E., Mount, V.S. 2001. Reactivation of an obliquely rifted margin, Campos and Santos basins, southeastern Brazil. American Association of Petroleum Geologists Bulletin, 85, 1925-1944.

Davies, R., Cloke, I., Cartwright, J., Robinson, A., Ferrero, C. 2004. Post-breakup compression of a passive margin and its impact on hydrocarbon prospectivity: An example 
from the Tertiary of the Faeroe-Shetland Basin, United Kingdom. American Association of Petroleum Geologists Bulletin, 88, 1-20.

Doré, A.G., Lundin, E.R., 1996. Cenozoic compressional structures on the NE Atlantic margin: nature, origin and potential significance for hydrocarbon exploration. Petroleum Geoscience, 2, 299-311.

Doré, A.G., Lundin, E.R., Jensen, L.N., Birkeland, O., Eliassen, P.E., Fichler, C., 1999. Principal tectonic events in the evolution of the northwest European Atlantic margin, in: Fleet, A.J., Boldy, S.A.R. (Eds.), Petroleum Geology of Northwest Europe, Proceedings of the $5^{\text {th }}$ Conference. The Geological Society, London, pp. 41-61.

Doré, A.G., Lundin, E.R., Kusznir, N.J., Pascal, C. 2008. Potential mechanisms for the genesis of Cenozoic domal structures on the NE Atlantic margin: pros, cons and some new ideas, in: Johnson, H., Doré, A.G., Gatliff, R.W., Holdsworth, R.W., Lundin, E.R., Ritchie, J.D. (Eds.), The Nature and Origin of Compression in Passive Margins. Geological Society, London, Special Publications, 306, 1-26.

Dorsey, R.J., Umhoefer, P.J., Renne, P.R., 1995. Rapid subsidence and stacked Gilbert-type fan deltas, Pliocene Loreto basin, Baja California Sur, Mexico. Sedimentary Geology, 98, $181-204$.

Elliott, G.M., Parson, L.M., 2008. Influence of margin segmentation upon the break-up of the Hatton Bank rifted margin, NE Atlantic. Tectonophysics, 457, 161-176.

Emery, D, Myers, M., 1996. Sequence Stratigraphy. Blackwell Science, Oxford.

Featherstone, P.S., Bott, M.H.P., Peacock, J.H., 1977. Structure of the continental margin of south-eastern Greenland. Geophysical Journal of the Royal Astronomical Society, 48, 15-27. 
Ferragne, A., Latouche, C., Parra, M., 1984. Lower Eocene Red-Clay Sedimentation on the George Bligh/Rockall Channel. Geo-Marine Letters, 4, 77-82.

Fowler, S.R., White, R.S., Westbrook, G.K., Spence, G.D., 1989. The Hatton Bank continental margin-II, deep structure from two-ship expanding spread seismic profiles. Geophysical Journal, 96, 295-309.

Fulthorpe, C.S., 1991. Geological controls on seismic sequence resolution. Geology, 19, 6165.

Gaina, C, Gernigon, L, Ball, P. 2009. Palaeocene-Recent plate boundaries in the NE Atlantic and the formation of the Jan Mayen microcontinent. Journal of the Geological Society, London, 166, 601-616.

Gradstein, F.M., Ogg, J.G., Smith, A.G., 2004. A Geologic Time Scale 2004. Cambridge University Press, Cambridge.

Green, P.F., Duddy, I.R., Hegarty, K.A. 2002. Quantifying exhumation from apatite-fission track analysis and vitrinite reflectance data: precision, accuracy and latest results from the Atlantic margin of NW Europe, in: Doré, A.G., Cartwright, J.A., Stoker, M.S., Turner, J.P., White, N. (Eds), Exhumation of the North Atlantic Margin: Timing, Mechanisms and Implications for Petroleum Exploration. Geological Society, London, Special Publications, 196, pp. 331-354.

Hawkes, J.R., Merriman, R.J., Harding, R.R., Darbyshire, D.P.F., 1975. Rockall Island: new geological, petrological, chemical and Rb-Sr data, in: Harrison, R.K. (Ed.), Expeditions to Rockall 1971-1972. Report of the Institute of Geological Sciences, 75/1, pp. 11-50. 
Hinz, K., 1981. A hypothesis on terrestrial catastrophes wedges of very thick oceanward dipping layers beneath passive continental margins - their origin and paleoenvironmental significance. Geologishes Jahrbuch, 22 (E), 3-28.

Hitchen, K., 1999. Rockall Continental Margin Project. Shallow Borehole Drilling Programme 1999. British Geological Survey Technical Report WB/99/21C.

Hitchen, K., 2004. The geology of the UK Hatton-Rockall margin. Marine and Petroleum Geology, 21, 993-1012.

Holford, S.P., Green, P.F., Duddy, I.R., Turner, J.P., Hillis, R.R., Stoker, M.S., 2009. Regional intraplate exhumation episodes related to plate-boundary deformation. Geological Society of America Bulletin, 121, 1611-1628.

Holford, S.P., Green, P.F., Hillis, R.R., Underhill, J.R., Stoker, M.S., Duddy, I.R. 2010. Multiple post-Caledonian exhumation episodes across NW Scotland revealed by apatite fission-track analysis. Journal of the Geological Society, London, 167, 675-694.

Holford, S.P., Hillis, R.R., Duddy, I.R., Green, P.F., Stoker, M.S., Tuitt, A.K., Backé, G., Tassone, D.R., McDonald, J.D. 2011. Cenozoic post-breakup compressional deformation and exhumation of the southern Australian margin. The Australian Petroleum Production and Exploration Association Journal, 51, 613-638.

Hudec, M.R., Jackson, M.P.A. 2002. Structural segmentation, inversion and salt tectonics on a passive margin: Evolution of the Inner Kwanza Basin, Angola. Geological Society of America Bulletin, 114, 1222-1244.

Johnson, H., Ritchie, J.D., Hitchen, K., McInroy, D.B., Kimbell, G.S., 2005. Aspects of the Cenozoic deformational history of the Northeast Faroe-Shetland Basin, Wyville-Thomson 
Ridge and Hatton Bank areas, in: Doré, A.G., Vining, B. (Eds.), Petroleum Geology: NorthWest Europe and Global Perspectives - Proceedings of the $6^{\text {th }}$ Petroleum Geology Conference. The Geological Society, London, pp. 993-1007

Johnson, N.M., Officer, C.B., Opdyke, N.D., Woodard, G.D., Zeitler, P.K., Lindsay, E.H., 1983. Rates of late Cenozoic tectonism in the Vallecito-Fish Creek basin, western Imperial Valley, California. Geology, 11, 664-667.

Jolley, D.W., 1996. The Stratigraphical and Palaeoenvironmental Distribution of the Tertiary Palynofloras in the BGS Rockall Wells 94/1, 94/2, 94/3, 94/4, 94/6 and 94/7. Report prepared for the Rockall Consortium, 15pp. (Open-File Access)

Jolley, D.W., Bell, B.R., 2002. The evolution of the North Atlantic Igneous Province and the opening of the NE Atlantic rift, in: Jolley, D.W., Bell, B.R. (Eds.), The North Atlantic Igneous Province: Stratigraphy, Tectonic, Volcanic and Magmatic Processes. Geological Society, London, Special Publications, 197, pp. 1-13.

Jones, E., Jones, R., Ebdon, C., Ewen, D., Milner, P., Plunkett, J., Hudson, G., Slater, P. 2003. Eocene, in: Evans, D., Graham, C., Armour, A., Bathurst, P. (Eds.), The Millenium Atlas: petroleum geology of the central and northern North Sea. (London: The Geological Society of London), pp. 261-277.

Jones, S.M., 2003. Test of a ridge-plume interaction model using oceanic crustal structure around Iceland. Earth and Planetary Science Letters, 208, 205-218.

Jones, S.M., White, N., MacLennan, J., 2002. V-shaped ridges around Iceland: Implications for spatial and temporal patterns of mantle convection. Geochemistry, Geophysics, Geosystems, 3, 1059, doi:10.1029/2002GC000361. 
Kimbell, G.S., Gatliff, R.W., Ritchie, J.D., Walker, A.S.D., Williamson, J.P., 2004. Regional three-dimensional gravity modelling of the NE Atlantic margin. Basin Research, 16, 259278.

Kimbell, G.S., Ritchie, J.D., Johnson, H., Gatliff, R.W., 2005. Controls on the structure and evolution of the NE Atlantic margin revealed by regional potential field imaging and 3D modelling, in: Doré, A.G., Vining, B. (Eds.), Petroleum Geology: North-West Europe and Global Perspectives - Proceedings of the $6^{\text {th }}$ Petroleum Geology Conference. The Geological Society, London, pp. 933-945.

Larsen, L.M., Waagstein, R., Pedersen, A.K., Storey, M., 1999. Trans-Atlantic correlation of the Palaeogene volcanic successions in the Faeroe Islands and East Greenland. Journal of the Geological Society, London, 156, 108-1095.

Larsen, M., Heilmann-Clausen, C., Piasecki, S., Stemmerik, L., 2005. At the edge of a new ocean: post-volcanic evolution of the Palaeogene Kap Dalton Group, East Greenland, Doré, A.G., Vining, B. (Eds.), Petroleum Geology: North-West Europe and Global Perspectives Proceedings of the $6^{\text {th }}$ Petroleum Geology Conference. The Geological Society, London, pp. 923-932.

Laughton, A.S., et al., 1972. Initial Reports of the Deep Sea Drilling Project, 12. U.S. Government Printing Office, Washington DC.

Lott, G.K., 1995. The petrographic description of selected core samples from boreholes drilled in the 1994 offshore drilling programme for the Rockall Project. British Geological Survey Technical Report, WH/95/217C. 
Lundin, E.R., Doré, A.G., 2002. Mid-Cenozoic post-breakup deformation in the 'passive' margins bordering the Norwegian-Greenland Sea. Marine and Petroleum Geology, 19, 7993.

Lundin, E.R., Doré, A.G., 2005. NE Atlantic break-up: a re-examination of the Iceland mantle plume model and the Atlantic-Arctic linkage, in: Doré, A.G., Vining, B. (Eds), Petroleum Geology: North West Europe and Global Perspectives. Proceedings of the $6^{\text {th }}$ Petroleum Geology Conference. The Geological Society, London, pp. 739-754.

Martinez, F., Taylor, B., Goodliffe, A.M. 1999. Contrasting styles of seafloor spreading in the Woodlark Basin: Indications of rift-induced secondary mantle convection. Journal of Geophysical Research, 104, 12,909-12,926.

McCubbin, D.G. 1982. Barrier-Island and Strand Plain Facies, in: Scholle, P.A., Spearing, D. (Eds.), Sandstone Depositional Environments. (Tulsa, Oklahoma, USA: The American Association of Petroleum Geologists), pp. 247-279.

McInroy, D.B., Hitchen, K., Stoker, M.S., 2006. Potential Eocene and Oligocene stratigraphic traps of the Rockall Plateau, NE Atlantic Margin, in: Allen, M.R., Goffey, G.P., Morgan, R.K., Walker, I. M. (Eds), The Deliberate Search for the Stratigraphic Trap. Geological Society, London, Special Publications, 254, pp. 247-266.

McKenzie, D., 1978. Some remarks on the development of sedimentary basins. Earth and Planetary Science Letters, 40, 25-32.

Menzies, M.A., Klemperer, S.L., Ebinger, C.J., Baker, J., 2002. Characteristics of volcanic rifted margins, in: Menzies, M.A., Klemperer, S.L., Ebinger, C.J., Baker, J. (Eds.), Volcanic Rifted Margins. Special Paper 362, Geological Society of America, Boulder, Colorado, pp. 1-14. 
Miller, K.G., Kominz, M.A., Browning, J.V., Wright, J.D., Mountain, G.S., Katz, M.E., Sugarman, P.J., Cramer, B.S., Christie-Blick, N., Pekar, S.F., 2005. The Phanerozoic Record of Global Sea-Level Change. Science, 310, 1293-1298.

Montadert, L., Roberts, D.G., et al., 1979. Initial Reports of the Deep Sea Drilling Project, 48. U.S. Government Printing Office, Washington DC.

Morgan, J.V., Barton, P.J., White, R.S., 1989. The Hatton Bank continental margin-III. Structure from wide-angle OBS and multichannel seismic refraction profiles. Geophysical Journal International, 98, 367-384.

Morton, A.C., 1984. Heavy minerals from Palaeogene sediments, Deep Sea Drilling Project Leg 81: Their bearing on stratigraphy, sediment provenance, and the evolution of the North Atlantic, in: Roberts, D.G., Schnitker, D., et al. (Eds.), Initial Reports of the Deep Sea Drilling Project, 81. U.S. Government Printing Office, Washington DC, pp. 653-661.

Morton, A.C., 1995a. Petrography and Geochemistry of Igneous and Metamorphic Rocks. Volume 5, Appendix 4, in: Stoker, M.S., Hitchen, K. (Eds.), Rockall Continental Margin Project: Final Geological Report. British Geological Survey Technical Report, WB/95/11C, (Five volumes).

Morton, A.C., 1995b. Heavy Minerals in Paleogene Sediments from Rockall and George Bligh Banks, West of Britain. British Geological Survey Technical Report, WH/95/205C.

Musgrove, F.W., Mitchener, B., 1996. Analysis of the pre-Tertiary rifting history of the Rockall Trough. Petroleum Geoscience, 2, 353-360. 
Naylor, D., Shannon, P., Murphy, N.J., 1999. Irish Rockall Basin region—a standard structural nomenclature system. Petroleum Affairs Division, Ireland, Special Publication, $1 / 99$.

Neal, J.E., 1996. A summary of Paleogene sequence stratigraphy in northwest Europe and the North Sea, in: Knox, R.W.O’B., Corfield, R.M., Dunay, R.E. (Eds.), Correlation of the Early Paleogene in Northwest Europe. Geological Society, London, Special Publications, 101, pp. $15-42$.

Olesen, O., Ebbing, J., Lundin, E., Mauring, E., Skilbrei, J.R., Torsvik, T.H., Hansen, E.K., Henningsen, T., Midbøe, P., Sand, M., 2007. An improved tectonic model for the Eocene opening of the Norwegian-Greenland Sea: Use of modern magnetic data. Marine and Petroleum Geology, 24, 53-66.

Olesen, O., Gellein, J., Gernigon, L., Kihle, O., Koziel, J., Lauritsen, T., Mogaard, J.O., Myklebust, R., Skilbrei, J.R., Usov, S., 2010. Magnetic anomaly map, Norway and adjacent areas. Scale 1: 3 million. Geological Survey of Norway.

Parkin, C.J., White, R.S., 2008. Influence of the Iceland mantle plume on oceanic crust generation in the North Atlantic. Geophysical Journal International, 173, 168-188.

Parkin, C.J., Lunnon, Z.C., White, R.S., Christie, P.A.F., iSIMM Team., 2007. Imaging the pulsing Iceland mantle plume through the Eocene. Geology, 35, 93-96.

Passey, S.R., Jolley, D.W., 2009. A revised lithostratigraphic nomenclature for the Palaeogene Faroe Islands Basalt Group, NE Atlantic Ocean. Earth and Environmental Science Transaction of the Royal Society of Edinburgh, 99, 127-158. 
Planke, S., Symonds, P.A., Alvestad, E., Skogseid, J., 2000. Seismic volcanostratigraphy of large-volume basaltic extrusive complexes on rifted margins. Journal of Geophysical Research-Solid Earth, 105, (B8), 19335-19351.

Postma, G., 1995. Sea-level-related architectural trends in coarse-grained delta complexes. Sedimentary Geology, 98, 3-12.

Praeg, D., Stoker, M.S., Shannon, P.M., Ceramicola, S., Hjelstuen, B., Laberg, J.S., Mathiesen, A., 2005. Episodic Cenozoic tectonism and the development of the NW European 'passive' continental margin. Marine and Petroleum Geology, 22, 1007-1030.

Quinn, M., Varming, T., Ólavsdottir, J. 2011. Petroleum Geology, in: Geology of the FaroeShetland Basin and adjacent areas. British Geological Survey Research Report, RR/11/01, Jarðfeingi Research report, RR/11/01, pp. 254-280.

Reineck, H.-E., Singh, I.B. 1980. Depositional Sedimentary Environments. (Berlin, Germany: Springer-Verlag.)

Ritchie, J.D., Gatliff, R.W., Richards, P.C., 1999. Early Tertiary magmatism in the offshore NW UK margin and surrounds, in: Fleet, A.J., Boldy, S.A.R. (Eds.). Petroleum Geology of Northwest Europe: Proceedings of the $5^{\text {th }}$ Conference. Geological Society, London, pp. 573584.

Ritchie, J.D., Johnson, H., Kimbell. G.S., 2003. The nature and age of Cenozoic contractional dating within the NE Faroe-Shetland Basin. Marine and Petroleum Geology, 20, 399-409.

Ritchie, J.D., Johnson, H., Quinn, M.F., Gatliff, R.W., 2008. Cenozoic compressional deformation within the Faroe-Shetland Basin and adjacent areas, in: Johnson, H., Doré, A.G., Holdsworth, R.E., Gatliff, R.W., Lundin, E.R., Ritchie, J.D. (Eds.), The Nature and Origin of 
Compression in Passive Margins. Geological Society, London, Special Publications, 306, pp. $121-136$.

Ritchie, J.D., Johnson, H., Kimbell, G., Quinn, M., 2012. Structure, in: Hitchen, K., Johnson, H. (Eds), Geology of the Rockall Basin. British Geological Survey Research Report, $\mathrm{RR} / 12 / ? ?$, in press.

Roberts, D.G., Backman, J., Morton, A.C., Murray, J.W., Keene, J.B., 1984. Evolution of volcanic rifted margins: synthesis of leg 81 results on the west margin of the Rockall Plateau, in: Roberts, D.G., Schnitker, D., et al. (Eds.), Initial Reports of the Deep Sea Drilling Project. U.S. Govt Printing Office, Washington D.C., pp. 883-911.

Sandwell, D.T., Smith, W.H.F., 1997. Marine gravity anomaly from Geosat and ERS 1 satellite altimetry. Journal of Geophysical Research, 102, 10039-10054.

Saunders, A.D., Larsen, H.C., Fitton, J.G., 1998. Magmatic development of the southeast Greenland margin and evolution of the Iceland Plume: geochemical constraints from Leg 152, in: Saunders, A.D., Larsen, H.C., Wise, S.E.Jr. (Eds), Proceedings of the Ocean Drilling Program, Scientific Results, 152. Ocean Drilling Program, College Station, Texas, pp. 479501.

Saunders, A.D., Fitton, J.G., Kerr, A.C., Norry, M.J., Kent, R.W., 1997. The North Atlantic Igneous Province, in: Mahoney, J.J., Coffin, M.L. (Eds.), Large Igneous Provinces: Continental, Oceanic, and Planetary Flood Volcanism. American Geophysical Union, Geophysical Monographs, 100, pp. 45-93.

Shipboard Scientific Party, 1994a. Shelf stratigraphic synthesis, in: Larsen, H.C., Saunders, A.D., Clift, P.D. et al. (Eds.), Proceedings of the Ocean Drilling Program, Initial Reports, 152. Ocean Drilling Program, College Station, Texas, pp. 159-175. 
Shipboard Scientific Party, 1994b. Summary and principal results. in: Larsen, H.C., Saunders, A.D., Clift, P.D. et al. (Eds.), Proceedings of the Ocean Drilling Program, Initial Reports, 152. Ocean Drilling Program, College Station, Texas, pp. 279-292.

Skogseid, J., Planke, S., Faleide, J.I., Pedersen, T., Eldholm, O., Neverdal, F., 2000. NE Atlantic continental rifting and volcanic margin formation, in: Nøttvedt, A. et al. (Eds), Dynamics of the Norwegian Margin. Geological Society, London, Special Publications, 167, pp. 295-326.

Sleep, N., 1971. Thermal effects of the formation of Atlantic continental margins by continental breakup. Geophysical Journal of the Royal Astronomical Society, 24, 325-350.

Smallwood, J.R., 2004. Tertiary inversion in the Faroe-Shetland Channel and the development of major erosional scarps, in: Davies, R.J., Cartwright, J.A., Stewart, S.A., Lappin, M., Underhill, J.R., (Eds.), 3D Seismic Technology: Application to the Exploration of Sedimentary Basins. Geological Society, London, Memoirs, 29, pp. 187-198.

Smallwood, J.R., White, R.S. 1998. Crustal accretion at the Reykjanes Ridge, $61^{\circ}-62^{\circ} \mathrm{N}$. Journal of Geophysical Research, B103, 5185-5201.

Smallwood, J.R., White, R.S., 2002. Ridge-plume interaction in the North Atlantic and its influence on continental breakup and seafloor spreading, in: Jolley, D.W., Bell, B.R. (Eds.), The North Atlantic Igneous Province: Stratigraphy, Tectonic, Volcanic and Magmatic Processes. Geological Society, London, Special Publications, 197, pp. 15-37.

Smith, L.K., White, R.S., Kusznir, N.J., iSIMM Team, 2005. Structure of the Hatton Basin and adjacent continental margin, in: Doré, A.G., Vining, B. (Eds), Petroleum Geology: North West Europe and Global Perspectives. Proceedings of the $6^{\text {th }}$ Petroleum Geology Conference. The Geological Society, London, pp. 947-956. 
Soh, W., Tanaka, T., Taira, A., 1995. Geomorphology and sedimentary processes of a modern slope-type fan delta (Fujikawa fan delta), Suruga Trough, Japan. Sedimentary Geology, 98, 79-95.

Spence, G.D., White, R.S., Westbrook, G.K., Fowler, S.R., 1989. The Hatton Bank continental margin-I, shallow structure from two-ship expanding spread profiles. Geophysical Journal, 96, 273-294.

Stoker, M.S., 1995a. Borehole Drilling Programme 1994. Volume 2, Appendix 1, in: Stoker, M.S., Hitchen, K. (Eds.), Rockall Continental Margin Project: Final Geological Report. British Geological Survey Technical Report, WB/95/11C, (Five volumes).

Stoker, M.S., 1995b. Shallow Sampling Programme 1994 - Stratigraphical Sites. Volume 3, Appendix 2, in: Stoker, M.S., Hitchen, K. (Eds.), Rockall Continental Margin Project: Final Geological Report. British Geological Survey Technical Report, WB/95/11C, (Five volumes).

Stoker, M.S., 1997. Mid- to Late Cenozoic sedimentation on the continental margin off NW Britain. Journal of the Geological Society, London, 154, 509-515.

Stoker, M.S., Hitchen, K, (Eds.), 1995. Rockall Continental Margin Project: Final Geological Report. British Geological Survey Technical Report, WB/95/11C, (Five volumes).

Stoker, M.S., Varming, T., 2010. Cenozoic (sedimentary), in: Ritchie, J.D., Ziska, H., Johnson, H., Evans, D. (Eds.), Geology of the Faroe-Shetland Basin and adjacent areas. British Geological Survey Research Report, RR/10/01, Jarðfeingi Research Report, RR/10/01, pp. 151-208. 
Stoker, M.S., van Weering, T.C.E., Svaerdborg, T., 2001. A Mid- to Late Cenozoic tectonostratigraphic framework for the Rockall Trough, in: Shannon, P.M., Haughton, P.D.W., Corcoran, D.V. (Eds), The Petroleum Exploration of Ireland's Offshore Basins. Geological Society, London, Special Publications, 188, pp. 411-438.

Stoker, M.S., Praeg, D., Shannon, P.M., Hjelstuen, B.O., Laberg, J.S., Nielsen, T., van Weering, T.C.E., Sejrup, H.P., Evand, D., 2005a. Neogene evolution of the Atlantic continental margin of NW Europe (Lofoten Islands to SW Ireland): anything but passive, in: Doré, A.G., Vining, B. (Eds), Petroleum Geology: North West Europe and Global Perspectives. Proceedings of the $6^{\text {th }}$ Petroleum Geology Conference. The Geological Society, London, pp. 1057-1076.

Stoker, M.S., Praeg, D., Hjelstuen, B.O., Laberg, J.S., Nielsen, T., Shannon, P.M., 2005b. Neogene stratigraphy and the sedimentary and oceanographic development of the NW European Atlantic margin. Marine and Petroleum Geology, 22, 977-1005.

Stoker, M.S., Holford, S.P., Hillis, R.R., Green, P.F., Duddy, I.R., 2010. Cenozoic post-rift sedimentation off NW Britain: recording the detritus of episodic uplift on a passive continental margin. Geology, 38, 595-598.

Taylor, B., Goodliffe, A., Martinez, F, Hey, R. 1995. Continental rifting and initial sea-floor spreading in the Woodlark basin. Nature, 374, 534-537.

Tegner, C., Duncan, R.A., Bernstein, S., Brooks, C.K., Bird, D.K., Storey, M., $1998 .{ }^{40} \mathrm{Ar}-$ ${ }^{39} \mathrm{Ar}$ geochronology of Tertiary mafic intrusions along the East Greenland rifted margin: Relation to flood basalts and the Iceland hotspot track. Earth and Planetary Science Letters, $156,75-88$. 
Tegner, C., Brooks, C.K., Duncan, R.A., Heister, L.E., Bernstein, S., 2008. ${ }^{40}$ Ar $-{ }^{39}$ Ar ages of intrusions in East Greenland: Rift-to-drift transition over the Iceland hotspot. Lithos, 101, $480-500$.

Tuitt, A., Underhill, J.R., Ritchie, J.D., Johnson, H., Hitchen, K., 2011. Timing, controls and consequences of compression in the Rockall-Faroe area of the NE Atlantic margin, in:

Vining, B., Pickering, S. (Eds.), Petroleum Geology: From Mature Basins to New Frontiers. Proceedings of the $7^{\text {th }}$ Petroleum Geology Conference. The Geological Society, London, 963-977

van Wagoner, J.C., Posamentier, H.W., Mitchum, R.M., Vail, P.R., Sarg, J.F., Loutit, T.S., Hardenbol, J., 1988. An overview of the fundamentals of sequence stratigraphy and key definitions, in: Wilgus, C.K., Hastings, C.G., St C Kendall, C.G., Posamentier, H.W., Ross, C.A., van Wagoner, J.C. (Eds.), Sea-Level Changes: An Integrated Aproach. Special Publication, Society of Economic Palaeontologists and Mineralogists, No. 42, pp. 39-45.

Verhoef, J., Roest, W.R., MacNab, R., Arkani-Hamed, J., et al., 1996. Magnetic anomalies of the Arctic and North Atlantic Oceans and adjacent land areas. Geological Survey of Canada Open File Report, No. 3125a.

Vogt, P.R., 1971. Asthenosphere motion recorded by ocean floor south of Iceland. Earth and Planetary Science Letters, 13, 153-160.

White, N., Lovell, B., 1997. Measuring the pulse of a plume with the sedimentary record. Nature, 387, 888-891.

White, N., Thompson, M., Barwise, T., 2003. Understanding the thermal evolution of deepwater continental margins. Nature, 426, 334-343. 
White, R.S., 1997. Rift-plume interaction in the North Atlantic. Philosophical Transactions of the Royal Society of London, Series A, 355, 319-339.

White, R.S., 1992. Crustal structure and magmatism of North-Atlantic continental margins. Journal of the Geological Society, London, 149, 841-854.

White, R.S., McKenzie, D.P., 1989. Magmatism at rift zones: the generation of volcanic continental margins and flood basalts. Journal of Geophysical Research, 94, 7685-7729.

White, R.S., Smith, L.K., 2009. Crustal structure of the Hatton and the conjugate east Greenland rifted volcanic continental margins, NE Atlantic. Journal of Geophysical Research, 114, B02305, doi:10.1029/2008JB005856.

White, R.S,, Bown, J,W, Smallwood, J,R., 1995. The temperature of the Iceland plume and origin of outward-propagating V-shaped ridges. Journal of the Geological Society, London, $152,1039-1045$.

Whittaker, J.M., Müller, R.D., Roest, W.R., Wessel, P., 2008. How supercontinents and superoceans affect seafloor roughness. Nature, 456, 938-941.

Wright, J.D., Miller, K.G., 1996. Control of North Atlantic Deep Water circulation by the Greenland-Scotland Ridge. Paleoceanography, 11, 157-170. 


\section{Figure and Table captions}

\section{Figure 1}

Location of Rockall Plateau and adjacent regions, boreholes and wells referred to in this paper. Abbreviations: AR, Ægir Ridge; CGFZ, Charlie Gibbs Fracture Zone; EH, Edoras High; FH, Fangorn High; FSB, Faroe-Shetland Basin; GBH, George Bligh High; HB, Hatton Basin; HH, Hatton High; KD, Kap Dalton; KR, Kolbeinsey Ridge; LH, Lorien High; MR Mohns Ridge; NSB, North Sea Basin; RR, Reykjanes Ridge; SH, Savoia Halvø. Box shows location of study area enlarged in Fig. 2.

\section{Figure 2}

Map of study area showing location of Eocene prograding sediment wedges (grey shaded units; black arrows show direction of progradation), BGS boreholes, seismic profiles (bold black lines) in Figs 3, 6 and 7, overall BGS seismic grid (grey lines) and location of schematic sections (black lines) shown in Fig. 5. Bathymetric contours in metres.

\section{Figure 3}

a) BGS airgun profile 92/01-26 and (b) interpreted line drawing across the East Rockall Wedge. Subdivision of wedge stratigraphy and definition of units incorporates information derived from BGS borehole 94/3 (Fig. 4). c) Wheeler diagram based on interpretation of profile 92/01-26, integrated with biostratigraphical data from 94/3. Timescale from Gradstein et al. (2004). Seismic profile located in Fig. 1. Abbreviation: WD, water depth.

\section{Figure 4}

Graphic log of BGS borehole 94/3 (see text for details). Abbreviations: FS, flooding surface; $\mathrm{SB}$, sequence boundary. 


\section{Figure 5}

Schematic cross-sections across the Rockall Plateau (based on regional mapping) illustrating the present-day stratigraphical disposition of seven of the Eocene prograding sediment wedges, in relation to the main structural elements, igneous centres (cf. Hitchen, 2004), and post-Eocene sediments. Of those wedges not shown, the North Rockall, NW Rockall and George Bligh wedges are comparable in setting to the East Rockall Wedge; the Sandarro Wedge is comparable to the Lyonesse Wedge. Locations of sections are shown in Fig. 1.

\section{$\underline{\text { Figure } 6}$}

BGS airgun profiles across: a) NW Rockall Wedge; b) West Rockall Wedge; and, c) George Bligh Wedge. Labels and abbreviations: C30, Late Eocene unconformity; C10, Early Pliocene unconformity; IR, reflections bounding internal Eocene packages; SBM, sea bed multiple; fp, fix point; TWTT, two-way travel time; msecs, milliseconds. Profiles are located in Fig. 2.

\section{Figure 7}

Airgun profiles across: a) East Lyonesse Wedge; b) Sandarro Wedge; c) North Hatton and Central Hatton wedges; and, d) North Hatton Wedge. Labels and abbreviations: C30, Late Eocene unconformity; C10 Early Pliocene unconformity; SBM, sea bed multiple; fp, fix point; TWTT, two-way travel time; msecs, milliseconds. Profiles are located in Fig. 2.

\section{Figure 8}


Stratigraphical-range chart and simplified lithology of BGS boreholes 94/2, 94/6 and 94/7 in comparison to 94/3. Core depths are cross-referenced to descriptions given in Table 6 (94/2, 6 and 7) and Fig. 4 (94/3). Timescale from Gradstein et al. (2004).

\section{$\underline{\text { Figure } 9}$}

Stratigraphical-range chart showing proposed correlation between Eocene prograding sediment wedges across the Rockall Plateau; arrows show range of uncertainty (see text for details). Timescale from Gradstein et al. (2004).

\section{$\underline{\text { Figure } 10}$}

Series of timeslice maps showing the inferred spatial and temporal development of the Rockall Plateau prograding sediment wedges (grey shaded units) during Eocene times (see text for details). Black arrows show directions of wedge progradation. Present-day bathymetric contours are superimposed on the maps to act as a guide to the morphology of the continental margin during the growth of the wedges, though current basinal water depths have only developed since Late Eocene times. Abbreviations: $\mathrm{CH}$, Central Hatton Wedge; EL, East Lyonesse Wedge; ER, East Rockall Wedge; ES, East Swithin Wedge; GB, George Bligh Wedge; L, Lyonesse Wedge; NH, North Hatton Wedge; NR, North Rockall Wedge; NWR, NW Rockall Wedge; S, Sandarro Wedge; WR, West Rockall Wedge. Area covered by maps located in Fig. 1.

\section{Figure 11}

Stratigraphical-range chart showing the correlation of Eocene continental margin sequences between NW Britain and SE Greenland. (based on various sources: see text for details). Timescale from Gradstein et al. (2004). 


\section{Figure 12}

Geophysical images of the North Atlantic region, between Rockall Plateau and the Reykjanes Ridge. (a) Free-air gravity anomalies based on satellite-derived data (Sandwell and Smith, 1997). (b) Total magnetic field anomalies based on the GAMMAA5 compilation (Verhoef et al., 1996) and BGS data. Colour shaded-relief displays with illumination from the NNW. Numbers is squares on the magnetic image indicate selected magnetic anomalies (e.g. 20 is equivalent to chron $\mathrm{C} 20 \mathrm{~N})$. The incoherent magnetic anomaly pattern in the SW corner is due to poor data coverage. Both images are annotated to illustrate changes in the oceanic crust discussed in the text (dashed black lines and numbers in circles): (1) Continent-ocean boundary (COB; after Kimbell et al, 2005); (2) boundary between smooth oceanic basement to the SE and transitional basement to the NW; (3) onset of fracturing; (4) fracturing fully developed; (5) boundary between segmented crust and V-shaped ridges. Abbreviations: ADL, Anton Dohrn Lineament; ES, Endymion Spur; HB, Hatton Basin; HH, Hatton High; IB, Iceland Basin; RB, Rockall Basin; RH, Rockall High; RR, Reykjanes Ridge.

\section{Figure 13}

Map showing thickness of crystalline crust in the Rockall-Iceland-Faroes region, from the model of Kimbell et al. (2004, 2005). Contours are at $2 \mathrm{~km}$ intervals. Crustal thickness is underestimated by up to about $5 \mathrm{~km}$ along the axis of the Iceland-Faroe Ridge but is closer to seismic estimates away from this axis (see Kimbell et al. (2004) for discussion). Dashed black lines and numbers in circles indicate changes in the oceanic crust discussed in the text (see caption to Fig. 12 for explanation). The axis of the positive magnetic anomaly associated with chron $\mathrm{C} 20 \mathrm{~N}$ is shown as a thick grey line. A and B are zones of thickened oceanic crust discussed in the text. The locations of the iSIMM Faroes $(\mathrm{F})$ and Hatton $(\mathrm{H})$ profiles are 
indicated. Abbreviations: ES, Endymion Spur; HB, Hatton Basin; HH, Hatton High; IB, Iceland Basin; RB, Rockall Basin.

\section{Figure 14}

Eocene tectonostratigraphy for the Rockall Plateau (UK sector) (see text for details).

Timescale from Gradstein et al. (2004).

\section{Figure 15}

Tentative correlation of Eocene unconformities with eustatic sea level and oxygen isotope curves derived from Neal (1996) and Abreu and Anderson (1998) (solid lines), and Miller et al. (2005) (dashed lines). Abbreviations: MY, Mid-Ypresian unconformity; LYU, Late Ypresian unconformity; MLU, Mid-Lutetian unconformity; LEU, Late Eocene unconformity (reflector C30).

\section{$\underline{\text { Table } 1}$}

Summary of Eocene biostratigraphy in BGS borehole 94/3, derived from detailed analysis presented in Stoker (1995a) and Jolley (1996).

\section{Table 2}

Lithological description of BGS borehole 94/3. Units 2, 7 and 10 divided into sub-units (see text for details).

$\underline{\text { Table } 3}$

Summary of heavy mineral analysis of samples from BGS borehole 94/3 (from Morton 1995b). 
$\underline{\text { Table } 4}$

Sediment accumulation rates on East Rockall Wedge fan-delta (units 3-11).

\section{$\underline{\text { Table } 5}$}

Summary of main seismic facies characteristics of the Rockall Plateau prograding sediment wedges.

$\underline{\text { Table } 6}$

Summary of Palaeogene stratigraphy in BGS boreholes 94/2, 94/6 and 94/7 derived from a detailed analysis presented in Stoker (1995a) and Lott (1995). A Quaternary veneer overlies the Palaeogene at all sites. Abbreviation: $m$ bsb, metres below sea bed. 
Fig 1

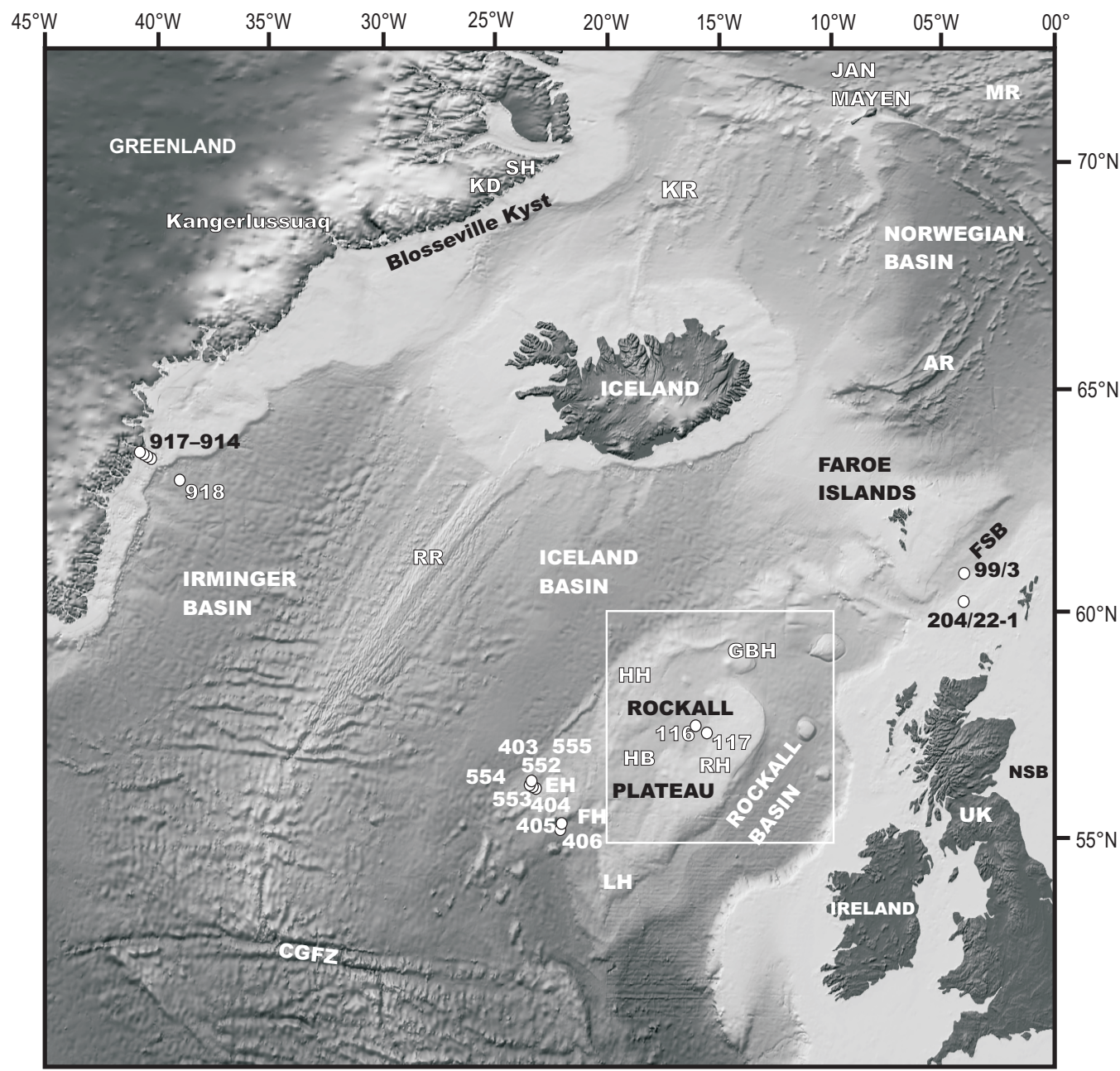


Fig 2

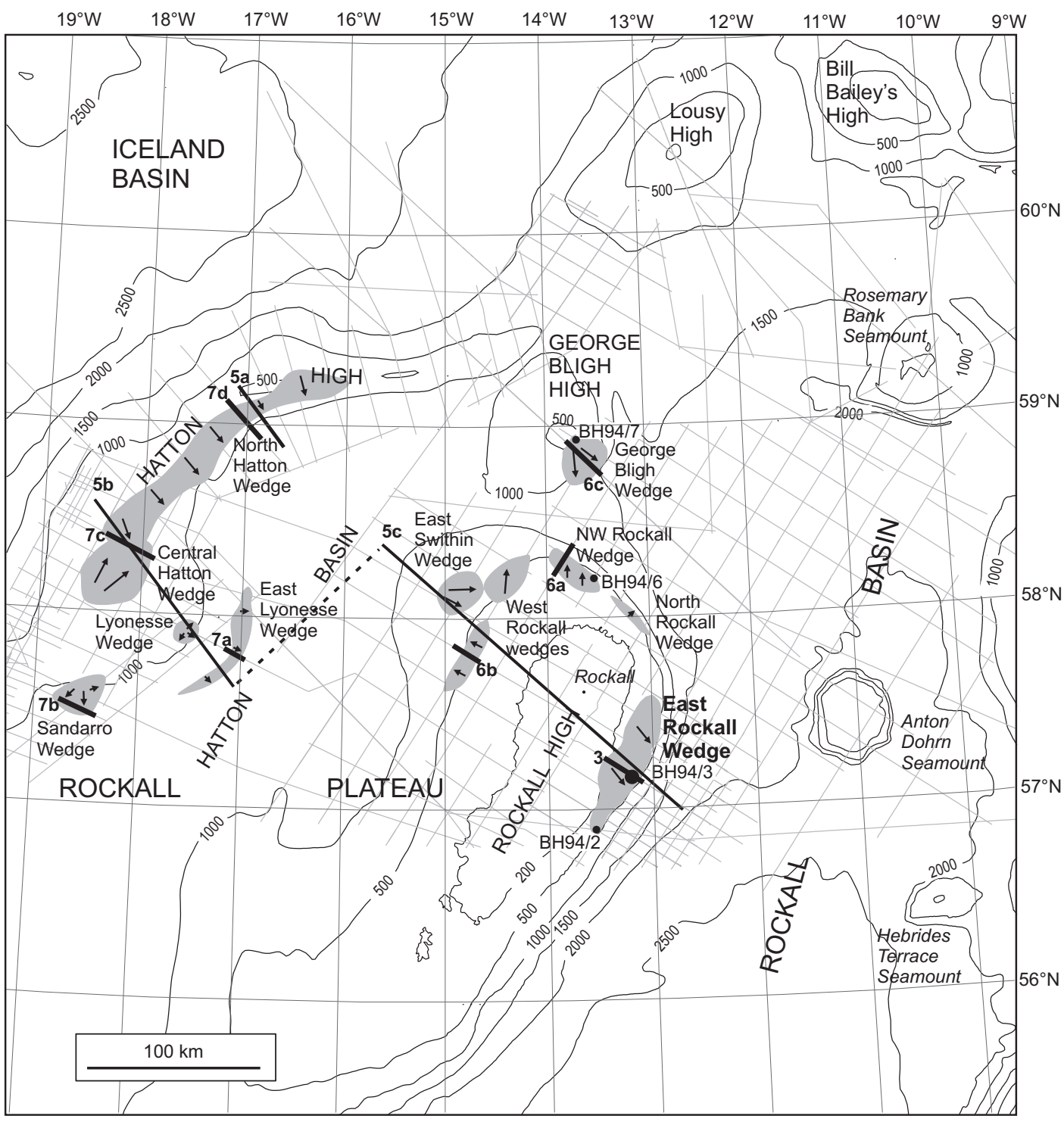


Fig 3

a

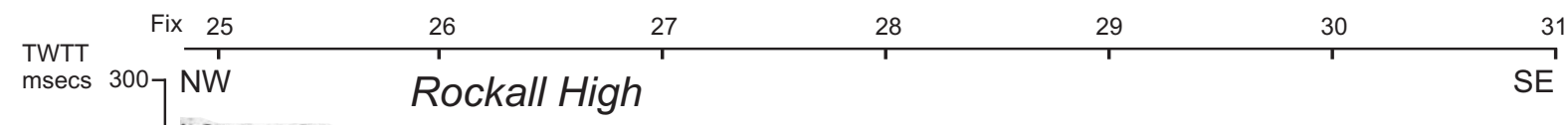

b $\begin{gathered}\text { Metres } \\ \text { belo } \\ \text { sea }\end{gathered}$

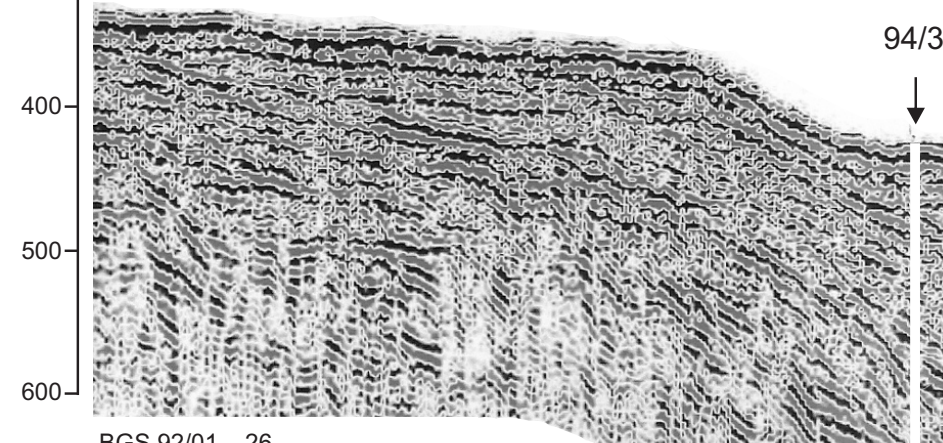

$94 / 3$

BGS 92/01- 26

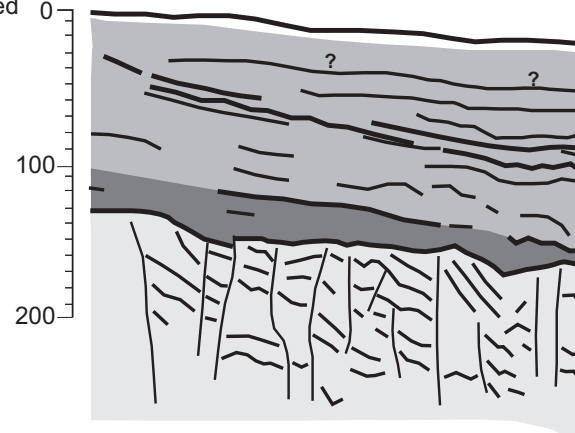

Key to sections
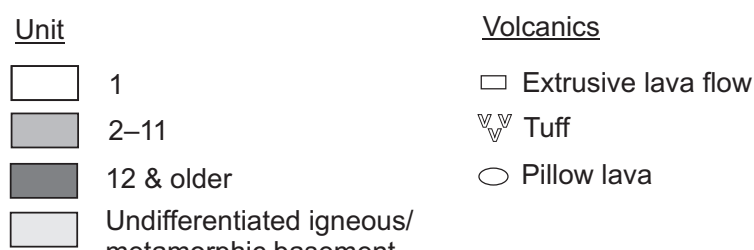

Undifferentiated igneous/ metamorphic basement

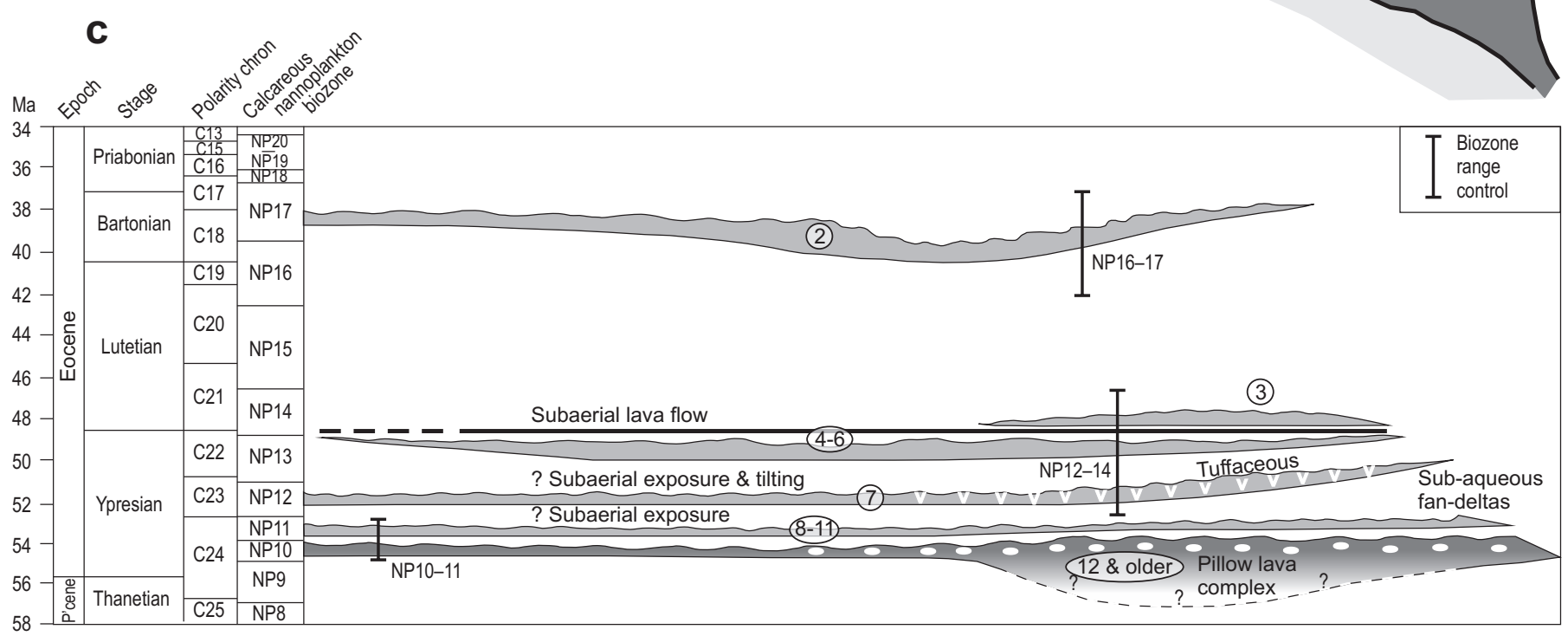




\section{Fig 4}

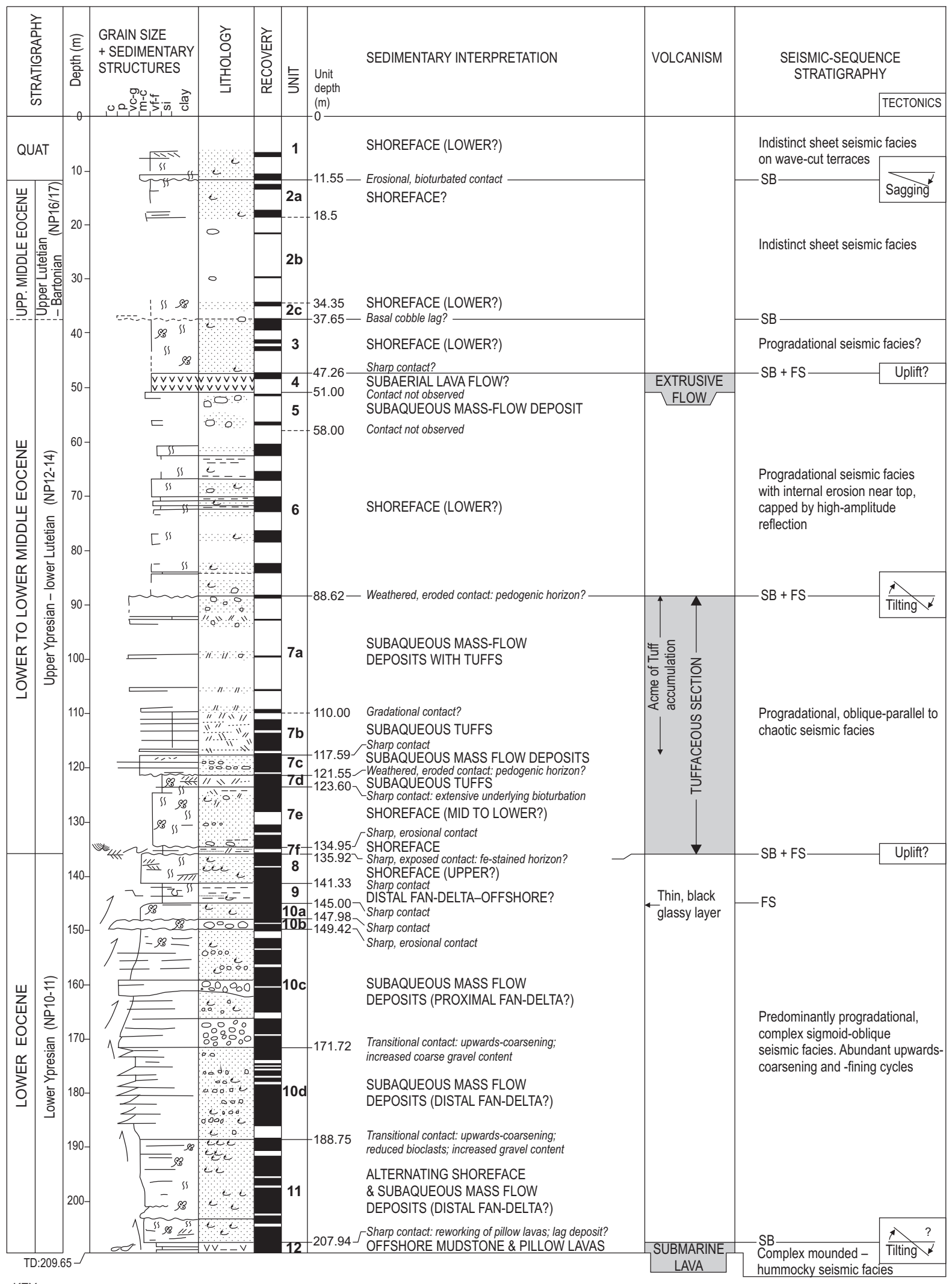

KEY

\begin{tabular}{|c|c|c|c|c|c|c|c|c|}
\hline 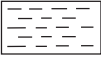 & Mudstone/siltstone & 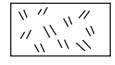 & Tuff & ec & Shell/shell fragment & III Planar cross-bedding & $\infty$ & Pillow lava \\
\hline & Sandstone & 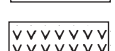 & Basalt & $\mathscr{B}$ & Organic matter & $\neg$ Sandstone dyke/injection & 1 & Upwards coarsening \\
\hline & Gallusturtie & 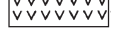 & Dasalt & siss & Bioturbation & tr Load cast & 1 & Upwards fining \\
\hline 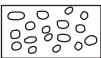 & Conglomerate & & $\begin{array}{l}\text { Core recovered } \\
\text { Core gap }\end{array}$ & 世 & Trough cross-bedding & $\simeq$ Slump & & \\
\hline
\end{tabular}


Fig 5

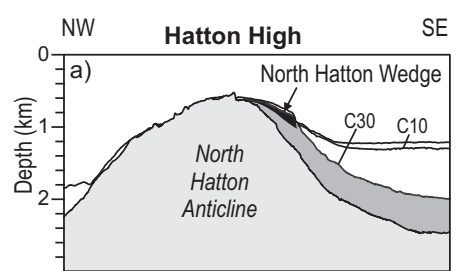

Section A approximately $100 \mathrm{~km}$ north of section B
KEY

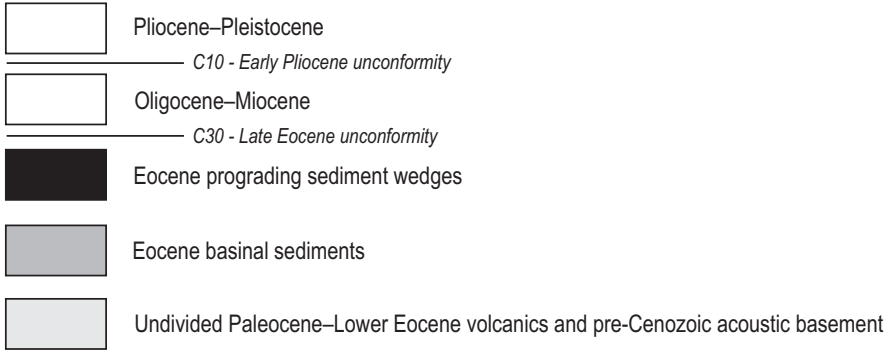

Hatton Basin

SE $\sim 110 \mathrm{~km}$
Rockall High

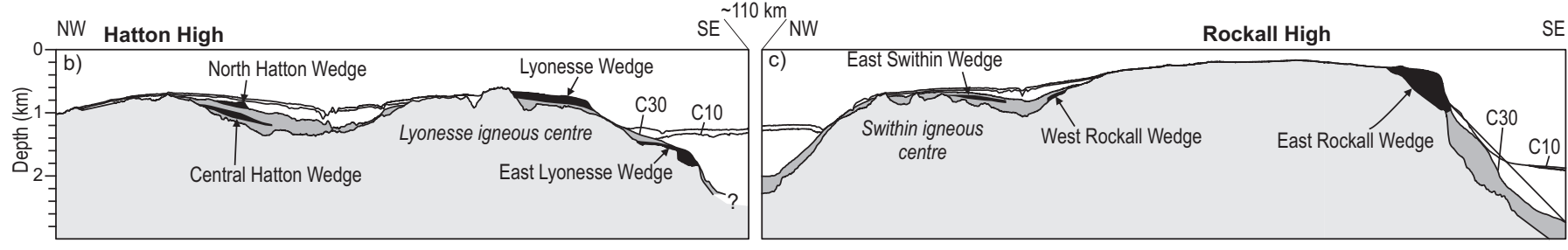




\section{Fig 6}

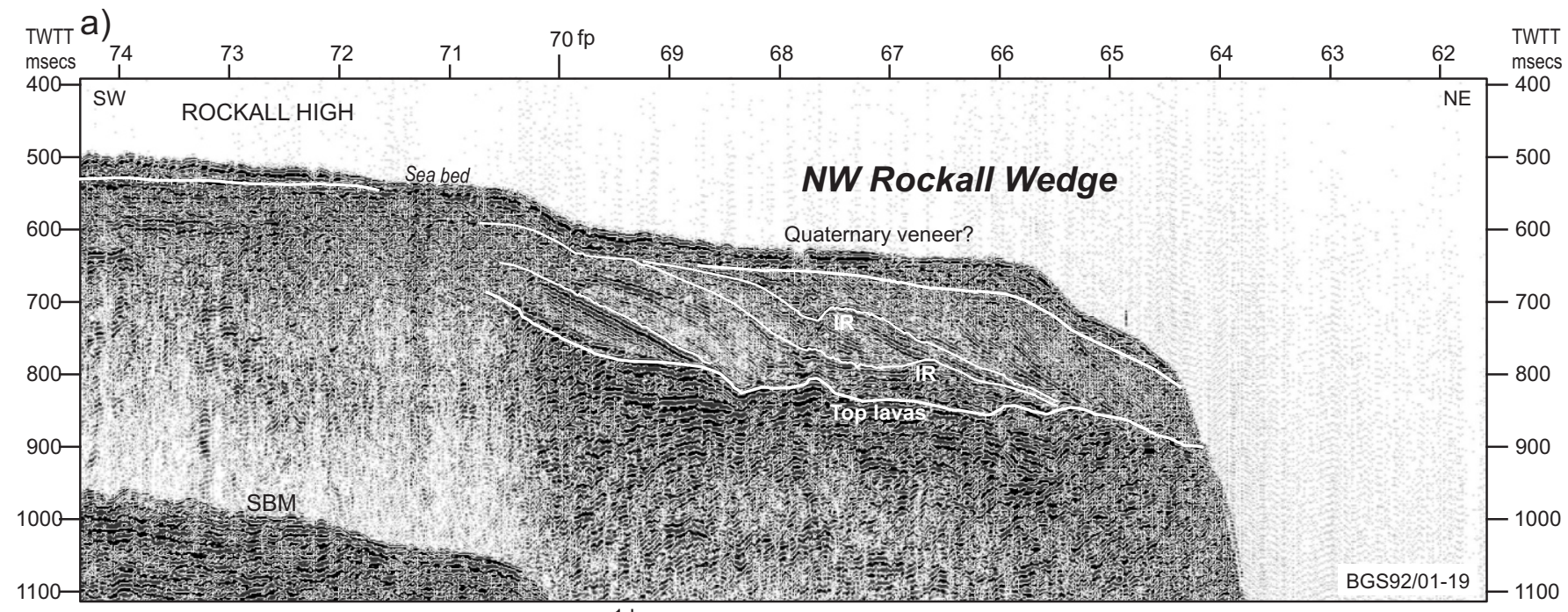

b)

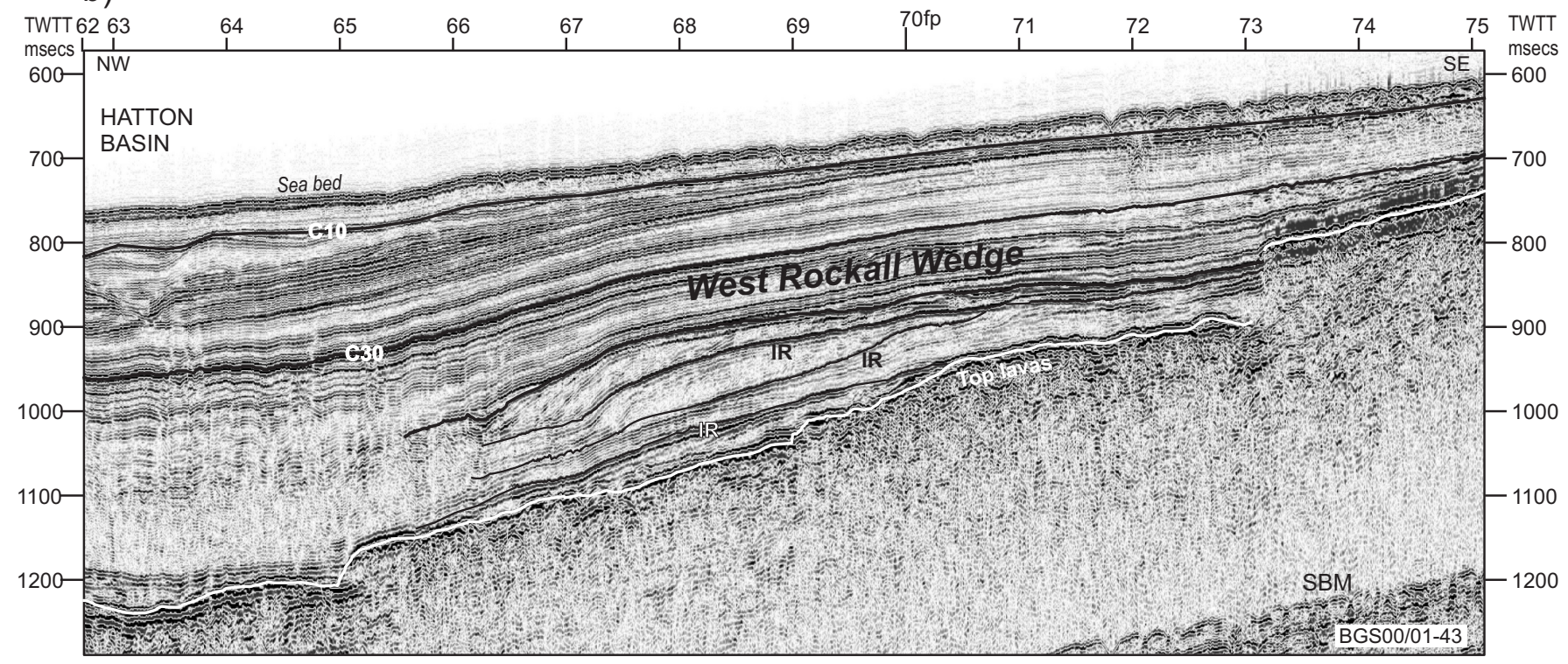

c)

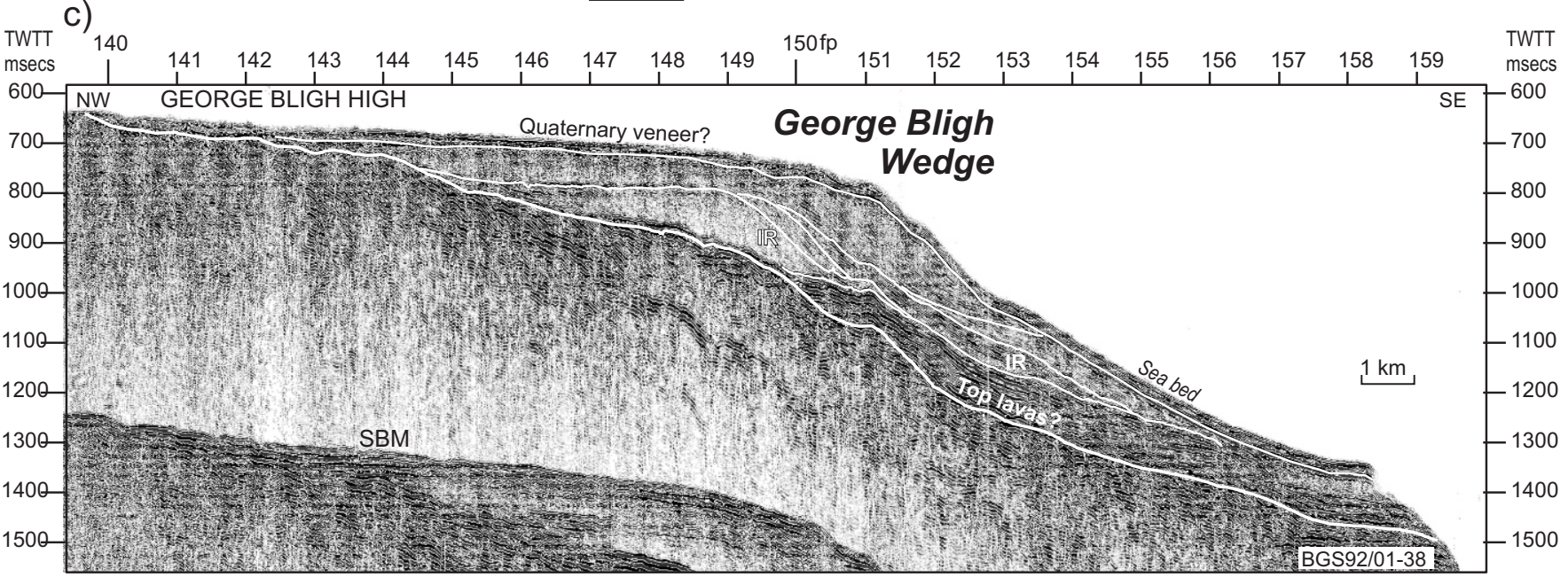




\section{Fig 7}
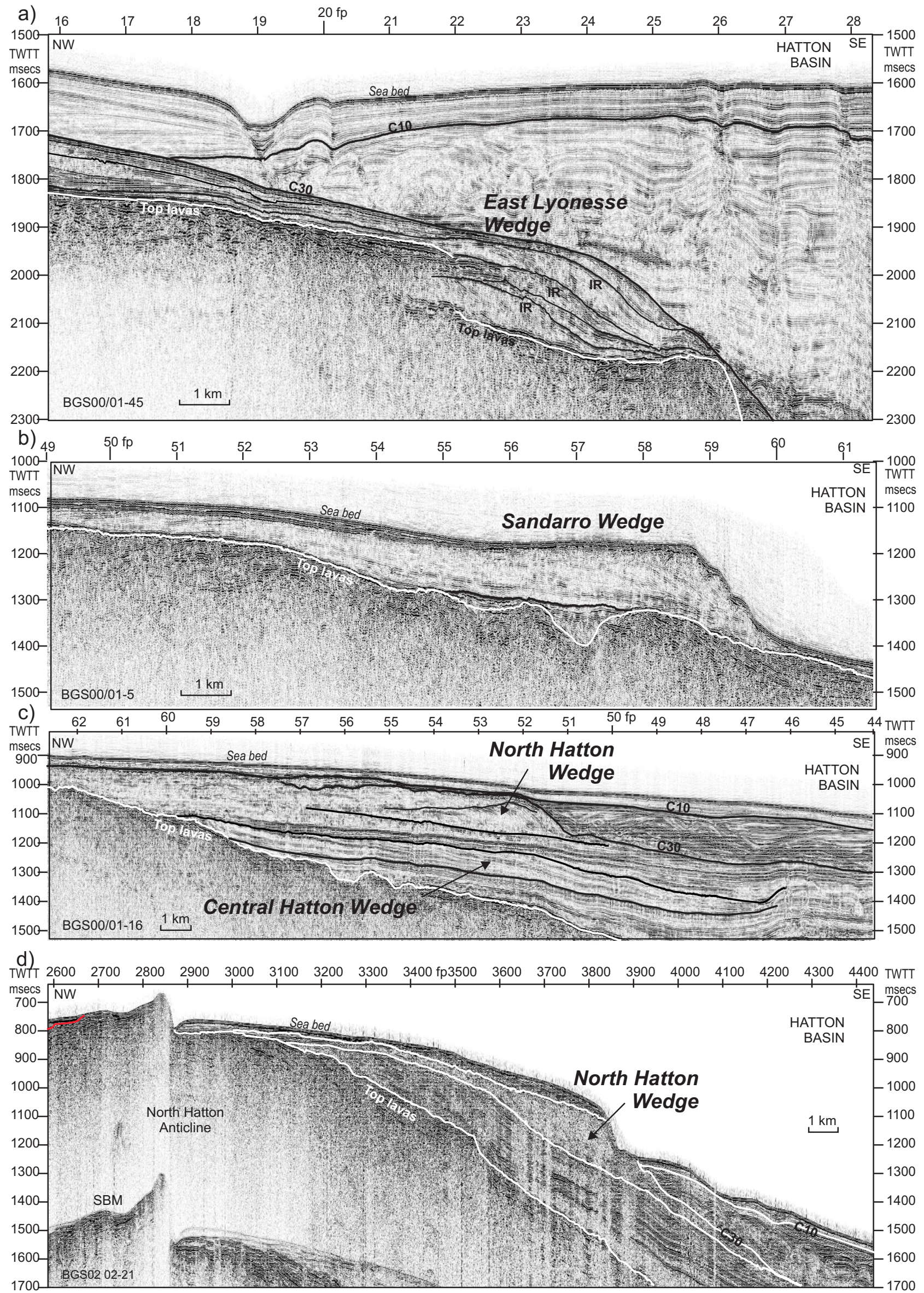
Fig 8

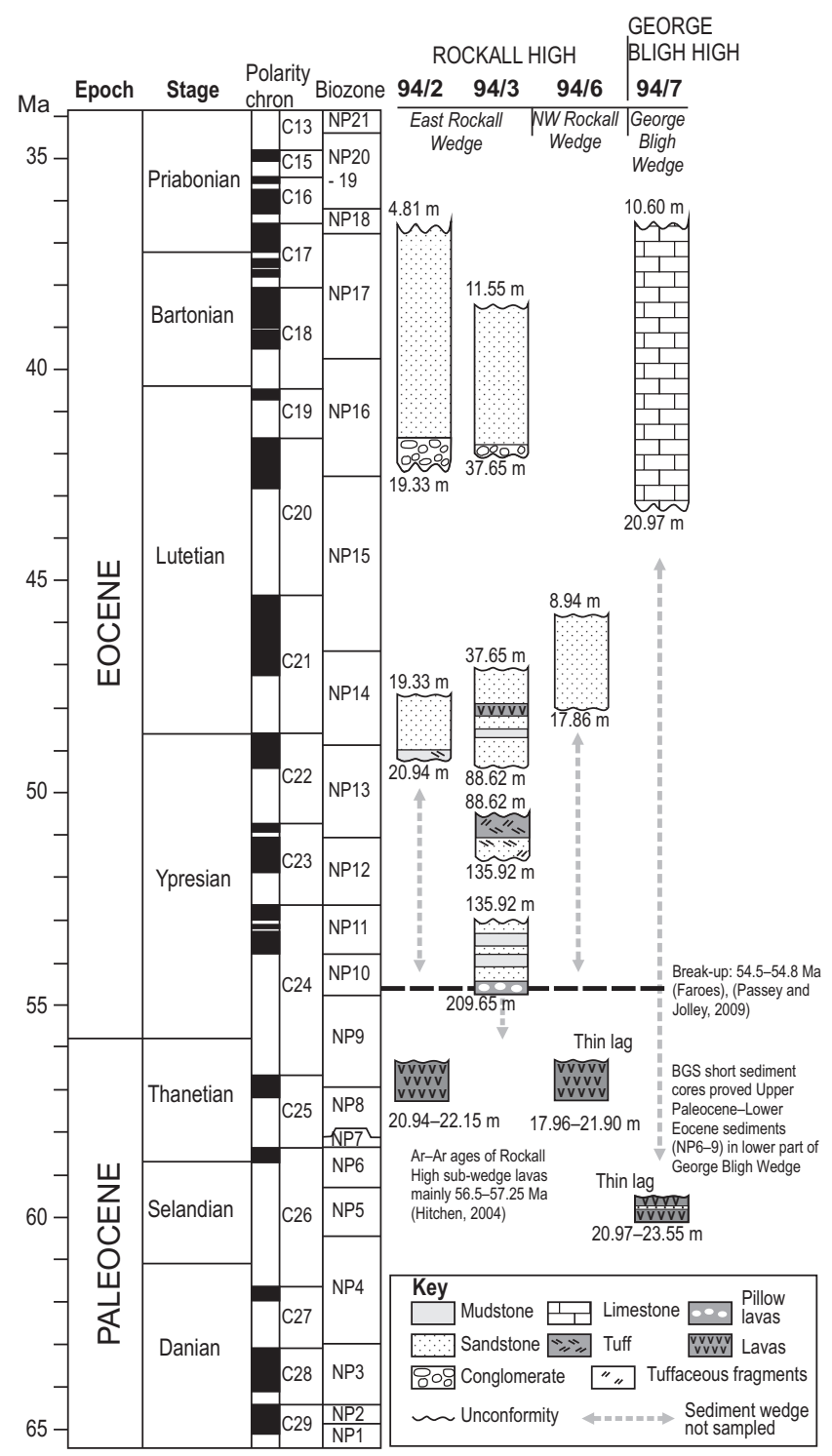


Fig 9

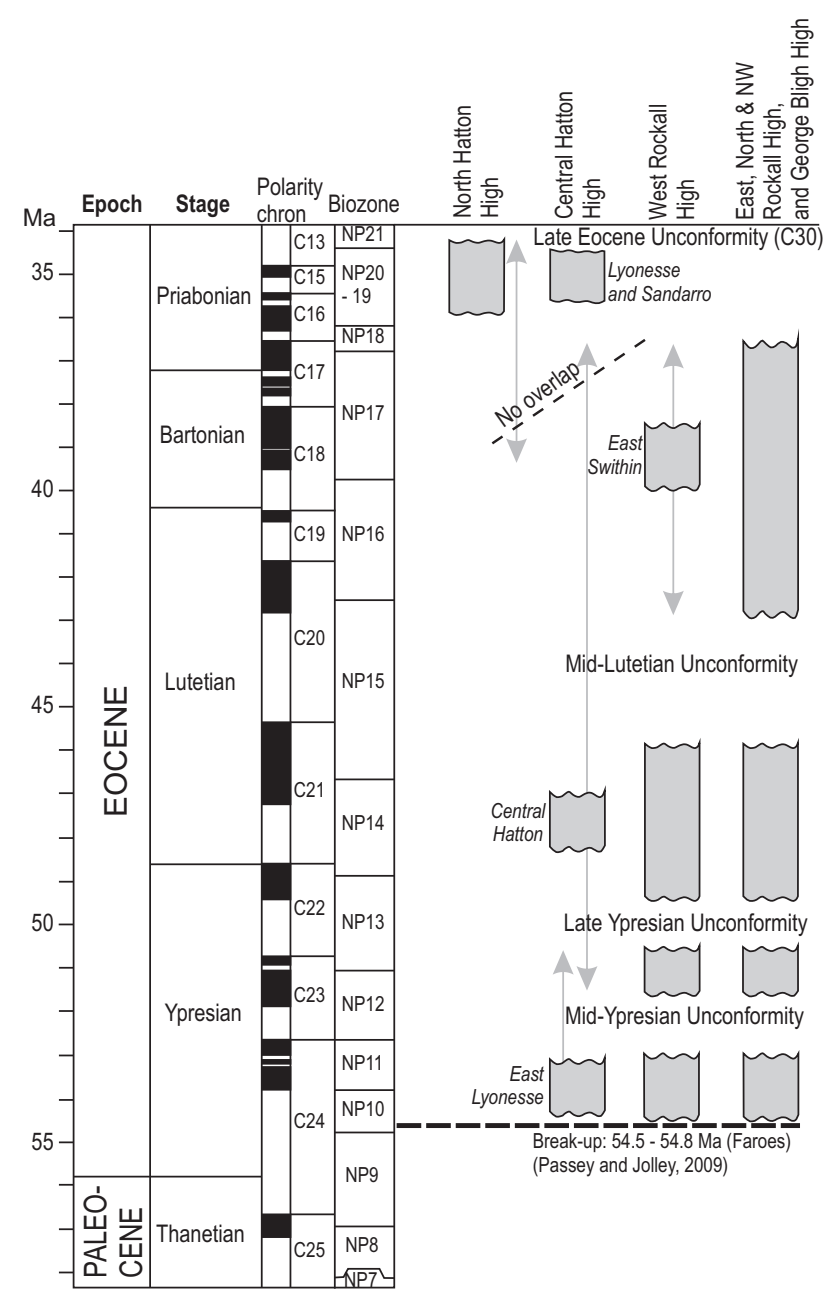


a) Early Ypresian

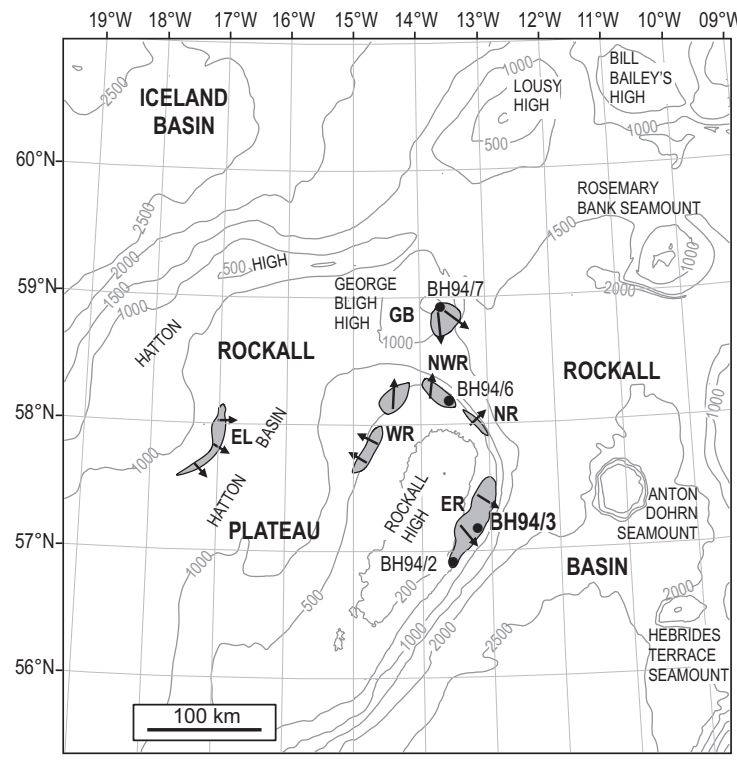

c) Late Lutetian-early Priabonian

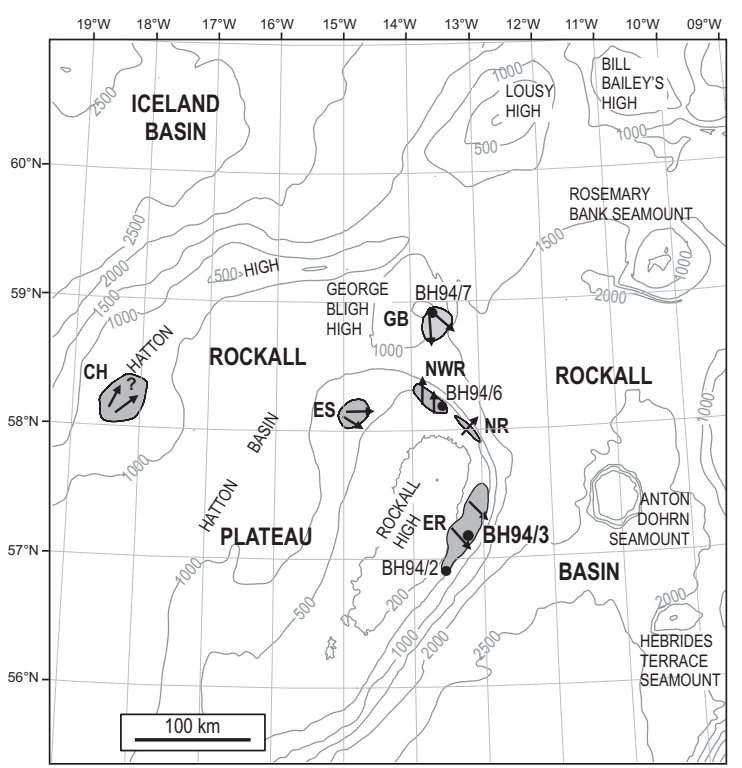

b) Late Ypresian-early Lutetian

$19^{\circ} \mathrm{W} \quad 18^{\circ} \mathrm{W} \quad 17^{\circ} \mathrm{W} \quad 16^{\circ} \mathrm{W} \quad 15^{\circ} \mathrm{W} \quad 14^{\circ} \mathrm{W} \quad 13^{\circ} \mathrm{W} \quad 12^{\circ} \mathrm{W} \quad 11^{\circ} \mathrm{W} \quad 10^{\circ} \mathrm{W} \quad 9^{\circ} \mathrm{W}$

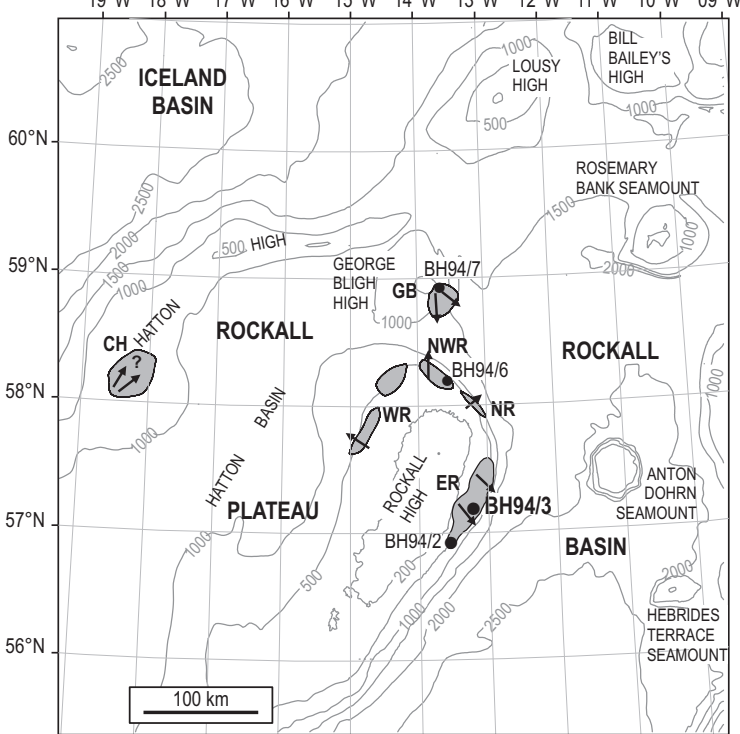

d) Late Lutetian/Bartonian-Priabonian?

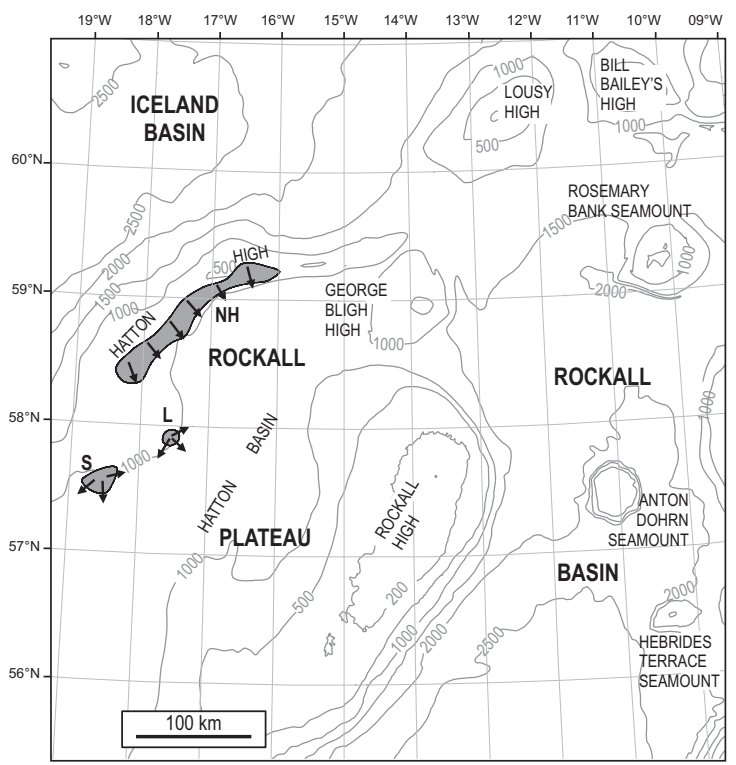




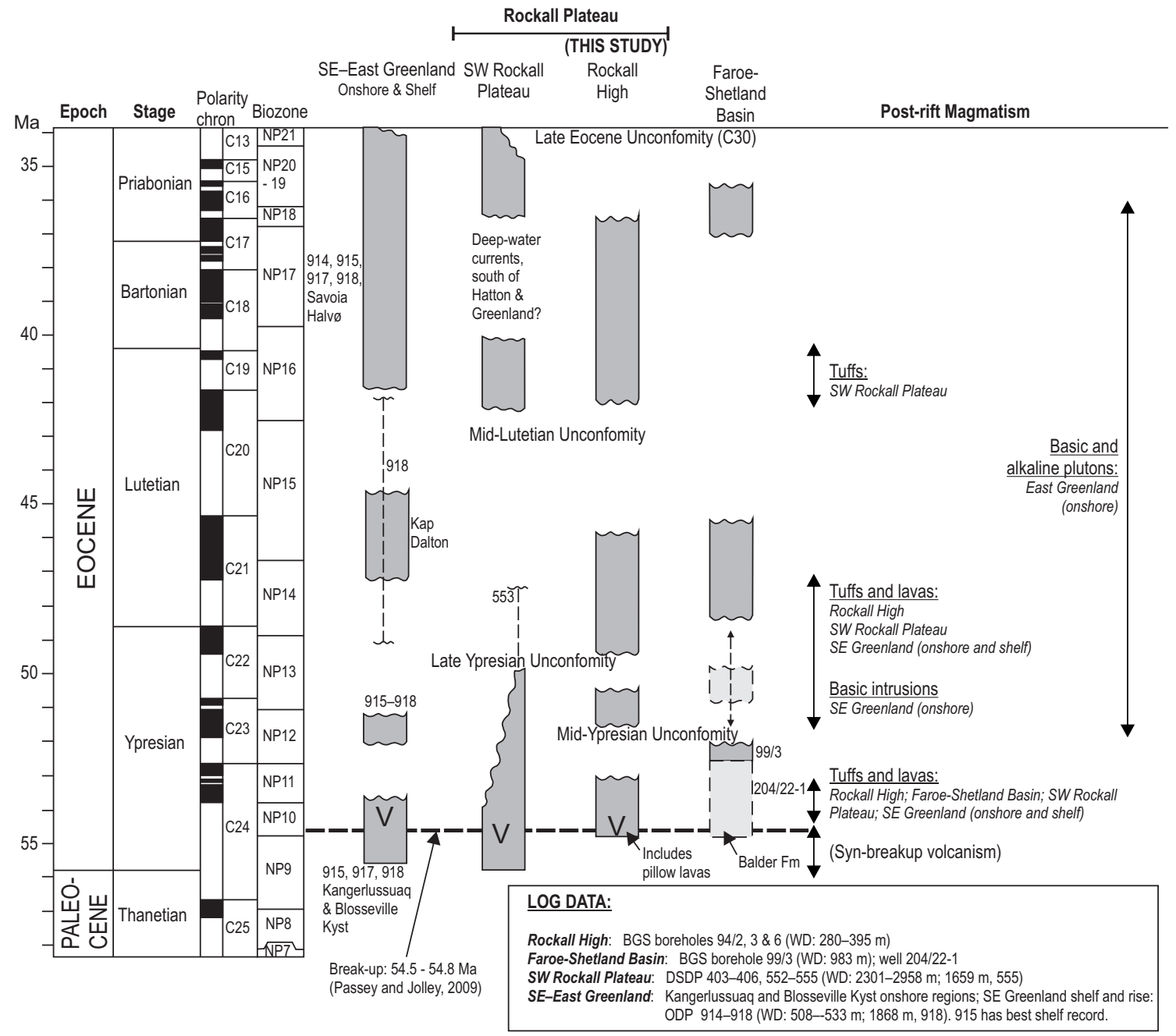


Fig. 12

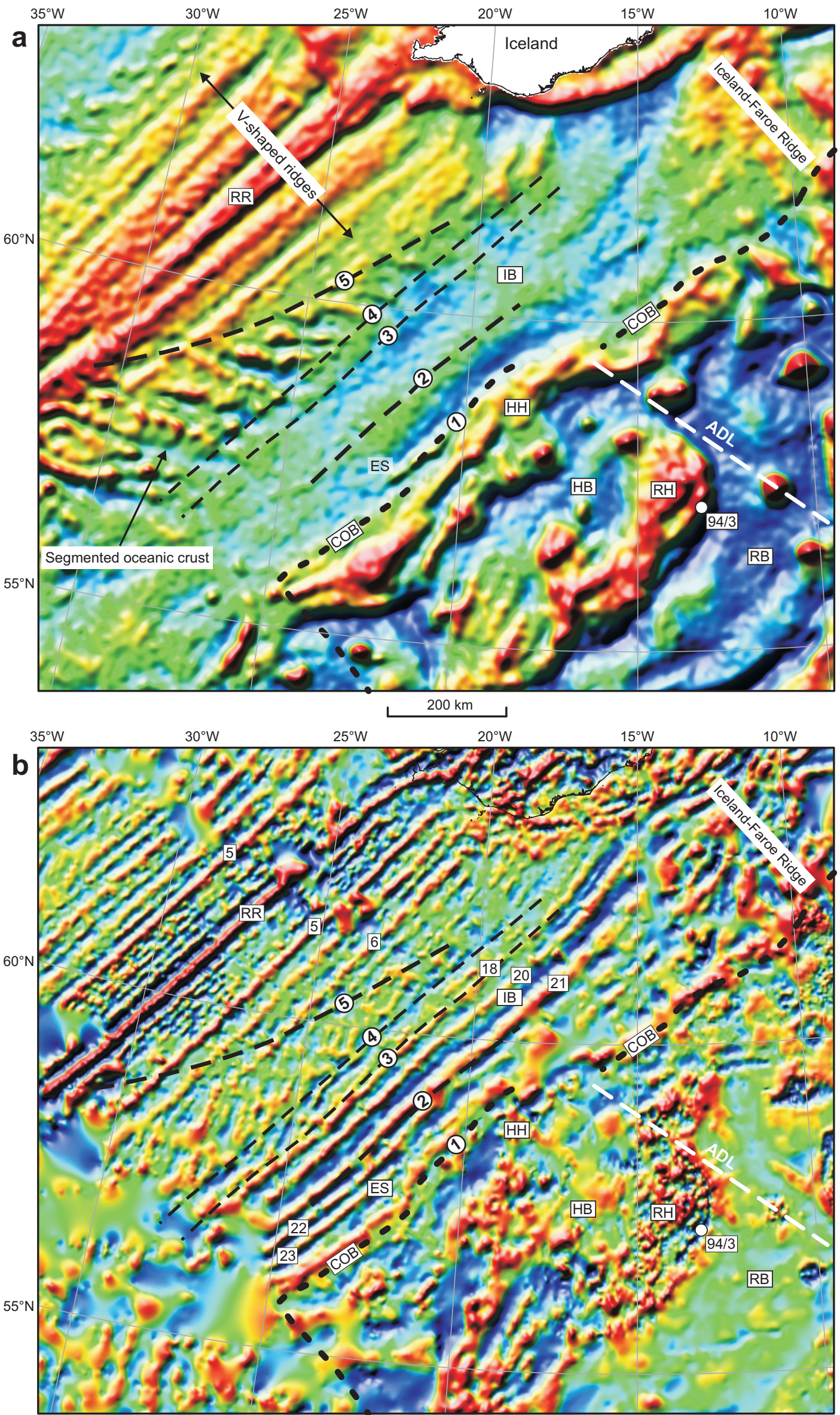


Fig 13

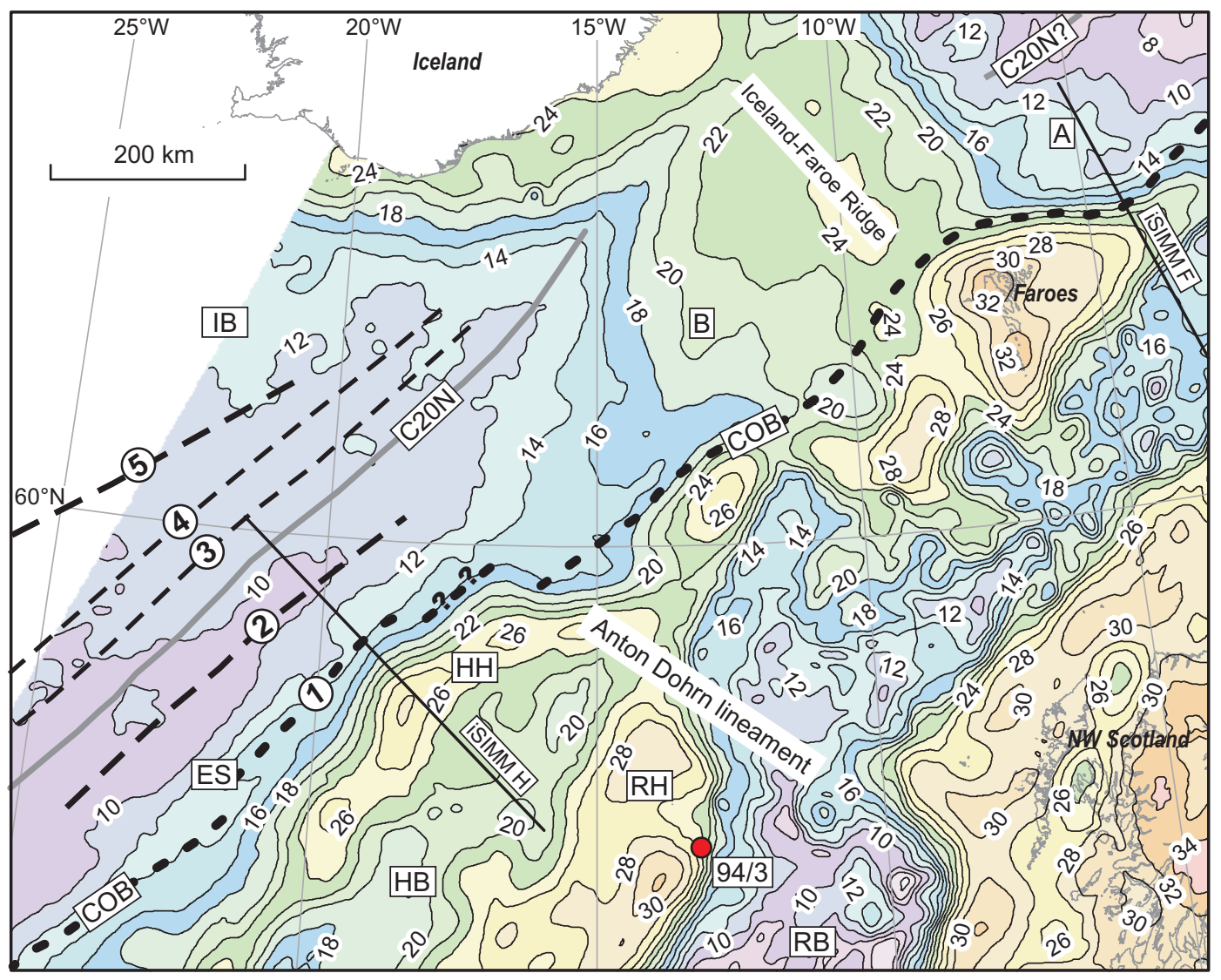




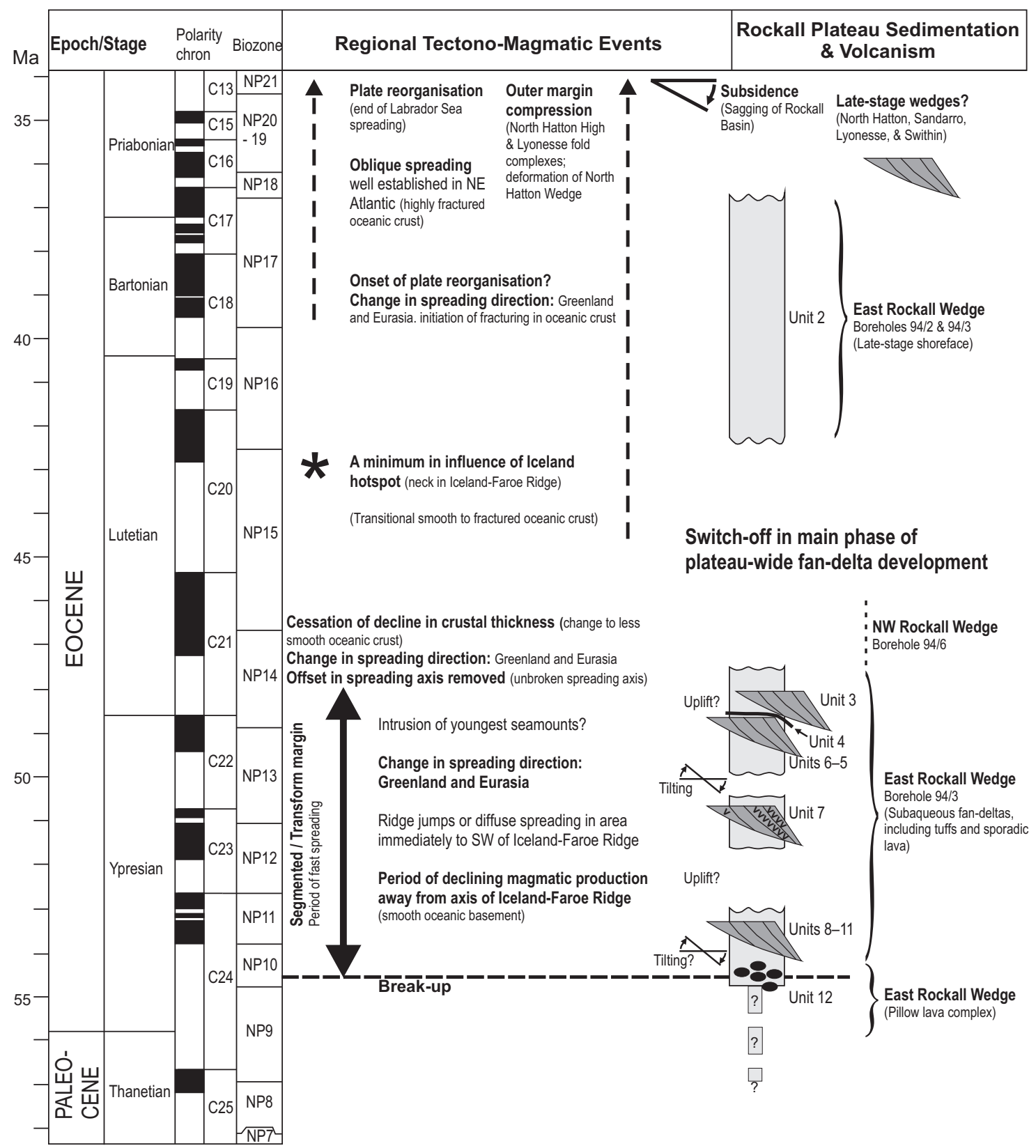


Fig 15

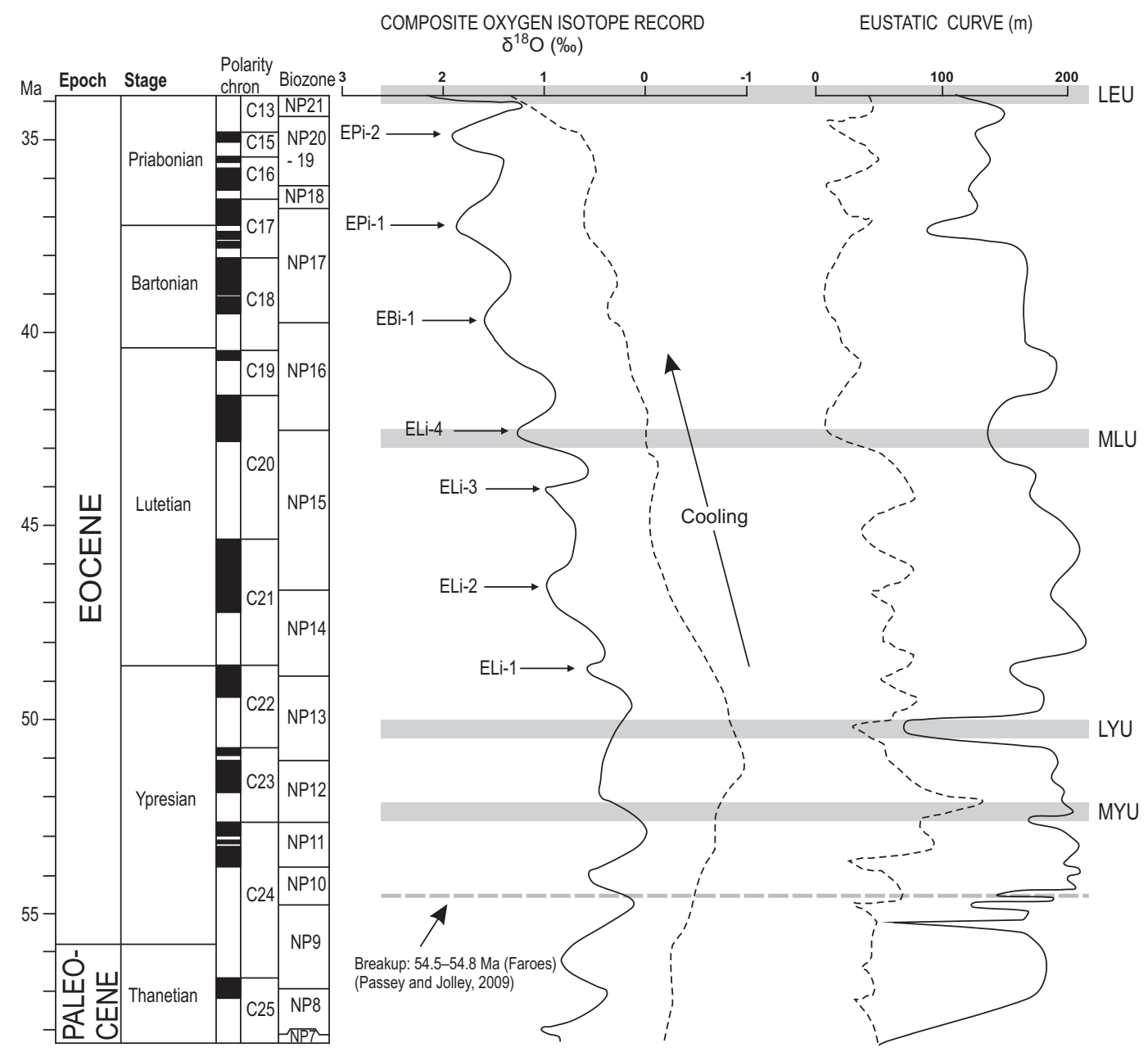


Table 1

\begin{tabular}{|c|c|c|}
\hline Depth in borehole & Biostratigraphical summary & Common age range \\
\hline \multirow[t]{5}{*}{$11.55-37.65 \mathrm{~m}$} & $\begin{array}{l}\text { Dinoflagellate cysts: Glaphyrocosta intricate, Phthanoperidinium geminatumi, Rottnestia } \\
\text { burussica, Wetzeliella lunaris and Wetzeliella cf. meckelfeldensis }\end{array}$ & $\begin{array}{l}\text { Late Mid-Eocene (NP16-17: Late } \\
\text { Lutetian-Bartonian }\end{array}$ \\
\hline & $\begin{array}{l}\text { Foraminifera: Globigerina ex gr. Linaperta, Psammosiphonella gr. discreta and } \\
\text { Trochammina cf. subvesicularis }\end{array}$ & \multirow{4}{*}{$\begin{array}{l}\text { Dinocysts Wetzeliella lunaris and } \\
\text { Wetzeliella cf. meckelfeldensis are } \\
\text { Early Eocene age, and indicative of } \\
\text { reworking. Calcareous nannofossils } \\
\text { are also likely reworked - } \\
\text { Paleocene (NP6-8) age }\end{array}$} \\
\hline & Calcareous nannofossils: Discoaster cf. megastypus, Chiasmolithus bidens, Prinsius & \\
\hline & $\begin{array}{l}\text { dimorphosus, Prinsius martini, Prinsius bisulcus, Toweius pertusus, Toweius selandianus, } \\
\text { Neochiastozygus saepes, Sphenolithus primus and Hornibrookina cf. australis }\end{array}$ & \\
\hline & $\underline{\text { Radiolara: Cenosphaera sp }}$ & \\
\hline \multirow[t]{4}{*}{ 37.65-135.92 m } & $\begin{array}{l}\text { Dinoflagellate cysts: Deflandrea phosphoritica, Deflandrea oebisfeldensis, Microdinium } \\
\text { cf. ornatum, Cordosphaeridium gracile, Wetzeliella lobisca, Tricolpites cf. hians, } \\
\text { Caryapollenites veripites, Sequoiapollenites polyformosus and Platycaryapollenites } \\
\text { platycaryoides }\end{array}$ & \multirow[t]{4}{*}{$\begin{array}{l}\text { Late Early to early Mid-Eocene } \\
\text { (NP12-14: Late Ypresian-early } \\
\text { Lutetian) }\end{array}$} \\
\hline & $\begin{array}{l}\text { Foraminifera: Planulites costata, Globigerina linaperta, Neoeponides karsteni and } \\
\text { Gaudryina hiltermanni }\end{array}$ & \\
\hline & Calcareous nannofossils: barren & \\
\hline & Radiolara: Cenosphaera sp. & \\
\hline \multirow[t]{3}{*}{ 135.92-209.65 m } & $\begin{array}{l}\text { Dinoflagellate cysts: Deflandrea oebisfeldensis, Microdinium cf. ornatum, } \\
\text { Adnatosphaeridium multispinosum, Adnatosphaeridium robustum, Achilleodinium } \\
\text { biformoides, Achomosphaera alcicornu, Cordosphaeridium gracile, Inaperturopollenites } \\
\text { hiatus and Tricolpites cf. hians }\end{array}$ & $\begin{array}{l}\text { Early Eocene (NP10-11: early } \\
\text { Ypresian). }\end{array}$ \\
\hline & $\begin{array}{l}\text { Foraminifera: Operculina sp, Guttulina communis, Cibicides simplex, Nutallides truempyi, } \\
\text { Anomalinoides howelli, Nummulites sp., Gavelinella danica and Gyroidina cf. } \\
\text { subangulatus }\end{array}$ & \multirow{2}{*}{$\begin{array}{l}\text { Calcareous nannofossils include } \\
\text { predominance of Prinsius and } \\
\text { Toweius species indicative of a } \\
\text { Paleocene (NP4-5/6: late Danian- } \\
\text { Thanetian) age: largely reworked? }\end{array}$} \\
\hline & $\begin{array}{l}\text { Calcareous nannofossils: Zygrhablithus bijugatus, Discoaster keupperi, Discoaster cf. } \\
\text { elegans, Chiasmolithus grandis, Prinsius dimorphosus, Prinsius martini, Toweius pertusus, } \\
\text { Toweius selandianus, Toweius eminens, Toweius magnicrassus, Sphenolithus primus, } \\
\text { Semihololithus kerabyi and Placozygus sigmoides }\end{array}$ & \\
\hline
\end{tabular}


Table 2

\begin{tabular}{lll}
\hline Unit & Depth & Description \\
\hline 1 & $0-11.55$ & $\begin{array}{l}\text { Very fine- to coarse-grained muddy SANDSTONE. Very dark grey to dark olive grey, very poorly sorted, with common scattered, matrix-supported granules, pebbles and } \\
\text { shell fragments, and isolated pebble layers. Medium to thick bedded with sharp to gradational contacts. Predominantly massive and bioturbated (including Planolites?, } \\
\text { Skolithos? and general biodeformational mottling), with sporadic tabular cross-bedding and coarse-tail (upwards-fining) grading in basal coarse-grained bed. Common black- } \\
\text { greenish volcanic grains. }\end{array}$
\end{tabular}

11.55-18.50 Very fine- to medium-grained muddy, volcaniclastic SANDSTONE. Dark olive grey, black and very dark grey, very poorly sorted, with common, scattered, matrix- to clastsupported, very coarse sand, granules and pebbles. Sporadic shell fragments. Predominantly massive; rare parallel lamination.

$2 \mathrm{~b} \quad 18.50-34.35$ Interval of poor recovery limited to two cobbles of sandstone and basalt, plus a compact 'ball' of muddy, very fine- to fine-grained sand.

2c $\quad 34.35-37.65$

Fine-grained, carbonate-cemented, volcaniclastic, silty SANDSTONE. Grey to dark grey, moderately sorted, with scattered shell fragments and organic material. Massive and extensively bioturbated (including Planolites?, Skolithos? and general biodeformational mottling). Base of unit possibly marked by quartzite cobble.

$3 \quad 37.65-47.26$

Very fine- to fine-grained, non-calcareous, volcaniclastic, silty SANDSTONE. Very dark grey to black, moderately sorted, with common organic/woody material and rare scattered shell (bivalve and gastropod) fragments. Massive and extensively bioturbated. Common coarse- to very coarse-grained, weakly calcareous, cemented sandstone 'clasts' observed between 38.5 and $41.7 \mathrm{~m}$.

$4 \quad 47.26-51.00$

Aphyric, sparsely vecisular BASALT. Highly fractured but lacking an obvious trachytic texture.

$5 \quad 51.00-58.00$

Muddy, pebbly, fine-grained, non-calcareous, volcaniclastic SANDSTONE and CONGLOMERATE. Dark greenish to dark olive grey, poorly sorted, lithic (igneous, tuff) clasts, angular to sub-rounded, pebble and cobble grade, matrix-to-clast-supported, largely disorganised though local hint of graded bedding (upwards fining).

$6 \quad 58.00-88.62$

Interbedded, volcaniclastic, olive, dark olive brown and dark grey brown, non-calcareous, SANDSTONE and SILTSTONE, and red-brown MUDSTONE. Sandstone is very fine- to medium-grained, silty, moderate to poorly sorted, with sporadic shell fragments and matrix-supported, coarse to very coarse grains and pebbles near the base of the section. Medium- to thick-bedded, predominantly massive and bioturbated, but local preservation of low-angle cross bedding. Siltstone and mudstone beds are medium to thin and bioturbated. Biodeformational mottling throughout, with common Planolites? and Skolithos? and rare Macaronichnus? Bed contacts mainly sharp, but locally gradational (upwards-fining).

Coarse- to very coarse-grained and pebbly, non-calcareous, volcaniclastic SANDSTONE and subordinate interbedded vitric andesitic TUFF, capped by red-stained regolith. Sandstone is olive to very dark grey brown, very poorly sorted, thin to medium bedded, with matrix- (to-clast-) supported, rounded to sub-angular pebbles, which define a Sandstone is olive to very dark grey brown, very poorly sorted, thin to medium bedded, with matrix- (to-clast-) supported, rounded to sub-angular pebbles, which define a
crude (long-axis) subhorizontal alignment. White tuffaceous grains disseminated throughout the sandstone; occur as isolated detrital grains as well as forming horizontal, crude (long-axis) subhorizontal alignment. White tuffaceous grains disseminated throughout the sandstone; occur as isolated detrital grains as well as forming horizontal, medium to thick laminae. Thicker accumulations of tuffaceous material form discrete thin beds, which increase in frequency towards the base of the unit. Top of unit marked
by a $0.23 \mathrm{~m}$-thick regolithic bed, which incorporates the underlying material, igneous pebbles, and the overlying sandstone preserved in burrows and/or fissures within the bed. by a $0.23 \mathrm{~m}$-thick regolithic bed, which incorporates the underlying material, igneous pebbles, and the overlying sandstone
The red staining implies the accumulation of iron-hydroxide minerals, commonly associated with the B-horizon of a soil.

Vitric andesitic TUFF with subordinate interbedded volcaniclastic SANDSTONE. Tuff beds vary from white to pale yellowish brown to greyish green, and consists of large particles of colourless, white or pale yellow highly vesicular volcanic glass, best described as pumice, intermixed with detrital sedimentary grains, including black volcanic
material. Pumice grains locally define a crude sub-horizontal alignment. Sandstone is medium- to coarse-grained, and slightly pebbly, and commonly preserved as medium material. Pumice grains locally define a crude sub-horizontal alignment. Sandstone is medium- to coarse-grained,
laminae to very thin beds; bed contacts vary from sharp to graded, with upward-coarsening couplets observed.

Stacked, graded, volcaniclastic, pebbly SANDSTONE and granule- to pebble-grade CONGLOMERATE. Sandstone is grey, thin to thick bedded, medium- to coarsegrained, poorly sorted, and non-calcareous, with common matrix-supported pebbles. Scoured surfaces and slumped bedding locally observed. Conglomerate ranges from discrete laminae to thin to medium beds that commonly display upwards-fining coarse-tail grading into the sandstone.

Greyish green TUFF with isolated, fine- to very fine-grained detrital layers (medium laminae), and scattered organic/woody fragments. Detrital layers locally inclined with bidirectional dips. Upper 10-15 cm of tuff is black, greyish green and yellow-brown, and may be a weathered top to the unit.

7e $\quad 123.60-134.95$

Very fine- to fine-grained, non-calcareous, volcaniclastic SANDSTONE with subordinate thin to medium beds of SILTSTONE and MUDSTONE. Sandstone is dark grey, moderately sorted, with common scattered tuffaceous grains (above $124.7 \mathrm{~m}$ ) and organic material, and rare shell fragments. Predominantly massive and bioturbated (Planolites?, Macoronichnus? and generally mottled), especially marked by black-stained subvertical pipes locally concentrated into bands, with sporadic hint of parallel lamination. Very dark grey mudstone at top of section is totally disrupted by bioturbation. Siltstone beds near base of section are laminated and bioturbated, and display smallscale ripples. Base of unit marked by a $0.18 \mathrm{~m}$-thick disorganised bed of siltstone clasts set in a medium- to fine-grained matrix.

Very thin to medium bedded SANDSTONE, SILTSTONE and TUFF. Sandstone is yellow-brown to greenish grey, very fine- to fine-grained, moderately sorted, with bidirectional tabular and trough cross-lamination, localised grading and scouring. Some mud drapes occur on rippled surfaces. Siltstone is red-brown, laminated, and locally rippled with trough cross sets. Slumped siltstone bed near base of unit overlies discrete, $5 \mathrm{~cm}$-thick tuff (lowest occurrence of tuff in this borehole), which has intermixed coarse detrital material at its base. Thin siltstone bed marks base of unit.

Medium- to coarse-grained, buff to grey, calcareous to non-calcareous, shelly, volcaniclastic SANDSTONE. Clean, moderately sorted, but with common, scattered, matrixsupported, very coarse sand to granule grade grains. Locally bioturbated. Thin to medium bedded, with planar horiziontal lamination, cross-bedded sets, including bidirectional tabular cross-bedding, and scour surfaces. Shell-rich and shell-poor beds; in former, shell debris commonly preserved as lags $2-4 \mathrm{~cm}$ thick. Shell debris also occurs as isolated disseminated fragments, as well as concentrated in burrows. Includes fragments of bivalves, serpulids and bryozoa. Top $30 \mathrm{~cm}$ is heavily bioturbated and stained yellow-brown.

141.33-145.00 Red-brown (at top) to grey-green, non-calcareous, MUDSTONE with subordinate fine- to very fine-grained SANDSTONE, including basal bed. Mudstone is very thin to thick bedded and laminated with very fine-grained sandstone partings, $1-2 \mathrm{~mm}$ thick. Laminations display parallel-, wavy- and cross-bedded structure, with locally erosive bases. Mudstone is bioturbated, and has rare shell fragments. Sandstone is very thin to thin bedded, moderately sorted, with sharp bed contacts, locally irregular and erosive, occasionally loaded. Some bioturbation, hint of cross-stratification and starved ripples, sand injection structures (dyke, ?volcano), and load casts.

Volcaniclastic, slightly calcareous, greenish grey, thick to very thick laminated SANDSTONE and massive SANDSTONE. Laminated sandstone (top of unit) is moderate to poorly sorted, with laminae varying from very fine- to medium-grained. Massive sandstone is poorly sorted, disorganised, medium- to coarse-grained, but with scattered, matrix-supported, very coarse sand and granules, and common organic/woody and shell fragments. Contact displays rapid grading (upwards-fining). Thin (5 mm) black layer at $145.55 \mathrm{~m}$, predominantly glassy appearance but incorporates a few sandy grains. Unclear if bedded or cross-cutting.

Very thick-bedded conglomerate (?), massive, disorganised, with intermixed cobble grade clasts of volcanic rock, bioturbated mudstone and siltstone, and medium- to coarsegrained shelly sandstone, which may be the matrix. Sharp upper contact. Basal $20 \mathrm{~cm}$ of unit consists of bioturbated (Planolites?) shelly sandstone, which has a scoured base grained shelly sandstone, which may be the
cut into the underlying laminated sandstone.

149.42-171.72 Stacked, graded, variably calcareous, muddy, volcaniclastic SANDSTONE and CONGLOMERATE. Sandstone is greenish grey in upper part of section, and pinkish grey in lower half (c. 160-172 m) of section, very poorly sorted, laminated thin to medium beds showing rapid alternation between fine- to medium- and medium- to coarse-grained material. Thin-bedded, matrix-to-clast-supported, granule to pebble grade conglomerates commonly display upwards-fining into the sandstone beds, the tops of which are often eroded by the overlying couplet. Organic/woody material is common above $153 \mathrm{~m}$; rare shell fragments occur throughout the sandstones. Very thick beds of granule to pebble grade, matrix-to-clast-supported, conglomerate occur about every $10 \mathrm{~m}$, including at the base and top of the unit. These grade upward into very coarse sandstones. An inclined channel base is preserved between 161.68 and $162.0 \mathrm{~m}$.

Stacked, graded, non-calcareous, muddy, volcaniclastic SANDSTONE and subordinate CONGLOMERATE. Sandstone is very dark greenish grey, poorly sorted, coarse- to very coarse-grained with common, scattered, matrix-supported pebbles. Internally, the sandstone is massive to locally crudely bedded with alternations of very thin to thin graded (upwards-fining) beds. Thin- to thick-bedded conglomerate-sandstone couplets comprise the dominant structure of the unit; beds predominantly fine upwards from clast-to-matrix-supported pebble conglomerate to sandstone. Scouring at the base of beds is common. Sporadic, randomly orientated, shell fragments are observed throughout the unit.

11 Medium- to coarse-grained, mainly calcareous, bioclastic and volcaniclastic SANDSTONE, which is very dark grey, dark greenish grey and black, and poorly sorted. Sandstone varies from very thin to very thick bedded as depicted by alternation of shell-rich and shell-poor beds, which include bivalve, serpulid and bryozoan fragments. Beds vary from massive and disorganised to crudely bedded; in former, shell fragments are randomly orientated and dispersed throughout the bed, whereas in the latter their orientation varies from subhorizontal (including thin lag deposits) to inclined (cross-bedding). Bioturbation is common in the bedded sandstone. Organic/woody material is scattered throughout the unit. Basalt pebbles and cobbles (from below) reworked into basal $0.5 \mathrm{~m}$ of unit: basal lag deposit? 
Table 3

\begin{tabular}{|c|c|c|}
\hline $\begin{array}{l}\text { Sample } \\
\text { depth (m) } \\
\text { and unit }\end{array}$ & Heavy mineral summary & $\begin{array}{l}\text { Interpretation of } \\
\text { provenance }\end{array}$ \\
\hline $\begin{array}{l}39.00 \\
\text { (Unit 3) }\end{array}$ & $\begin{array}{l}\text { Predominantly clinopyroxene } \\
\text { (>70\%), albeit relatively } \\
\text { heterogeneous in composition }{ }^{\mathrm{a}} \text {. } \\
\text { Most grains are augitic, though } \\
\text { some fall in the diopside and } \\
\text { endiopside fields. } \\
\text { Heterogeneous alkaline suite of } \\
\text { minerals also present, including } \\
\text { aegirine and sodic amphibole, as } \\
\text { well as aenigmatite (8\%). }\end{array}$ & $\begin{array}{l}\text { Erosion of a range of } \\
\text { basaltic rocks, as well } \\
\text { as alkaline material } \\
\text { related to the Rockall } \\
\text { aegerine granite. }\end{array}$ \\
\hline $\begin{array}{l}72.90 \\
\text { (Unit 6) }\end{array}$ & $\begin{array}{l}\text { Reduced clinopyroxene } \\
\text { component ( } 32 \%) \text {, which is also } \\
\text { relatively restricted in } \\
\text { composition }^{\text {a }} \text { (augite and salite). } \\
\text { Major alkaline suite with } \\
\text { aegerine, sodic amphibole and } \\
\text { sodic-calcic amphibole } \\
\text { comprising } 58 \% \text { of the } \\
\text { assemblage. }\end{array}$ & $\begin{array}{l}\text { Erosion of basaltic } \\
\text { terrain with limited } \\
\text { compositional } \\
\text { variation, as well as } \\
\text { alkaline material } \\
\text { similar to the Rockall } \\
\text { aegerine granite. }\end{array}$ \\
\hline $\begin{array}{l}125.60 \\
\text { (Sub-unit } \\
7 e)\end{array}$ & $\begin{array}{l}\text { Predominantly clinopyroxene } \\
\text { (94\%), but with a wide } \\
\text { compositional scatter }^{\mathrm{a}} \text { mainly } \\
\text { within the augite--salite range. }\end{array}$ & $\begin{array}{l}\text { Erosion of a range of } \\
\text { basaltic rocks. }\end{array}$ \\
\hline $\begin{array}{l}181.56 \\
\text { (Sub-unit } \\
\text { 10d) }\end{array}$ & $\begin{array}{l}\text { Predominantly clinopyroxene } \\
\text { (>75\%) of restricted salitic } \\
\text { composition }{ }^{\mathrm{a}} \text {. Zircon and } \\
\text { corroded garnet is also present. }\end{array}$ & $\begin{array}{l}\text { Erosion of a basaltic } \\
\text { terrain with a } \\
\text { restricted lithology, } \\
\text { together with recycling } \\
\text { of older sediments }\end{array}$ \\
\hline
\end{tabular}

${ }^{\mathrm{a}}$ In terms of $\mathrm{TiO}_{2}$ and $\mathrm{Al}_{2} \mathrm{O}_{3}$ contents, and $\mathrm{FeO} / \mathrm{MgO}$ ratio 
Table 4

\begin{tabular}{llll}
\hline Unit & $\begin{array}{l}\text { Borehole } \\
\text { thickness (m) }\end{array}$ & $\begin{array}{l}\text { Seismic } \\
\text { profile, } \\
\text { maximum } \\
\text { preserved } \\
\text { thickness (m) }\end{array}$ & $\begin{array}{l}\text { Sediment accumulation } \\
\text { rate }\left(\mathrm{mm} \mathrm{a}^{-1}\right) . \\
0.1-1.0 \mathrm{Ma} \text { duration }\end{array}$ \\
\hline 3 & 9.61 & 60 & $0.6-0.06$ \\
$5-6$ & 37.62 & 50 & $0.5-0.05$ \\
7 & 47.30 & 65 & $0.65-0.065$ \\
$8-11$ & 72.02 & 75 & $0.75-0.075$ \\
\hline
\end{tabular}


Table 5

\begin{tabular}{ll}
\hline $\begin{array}{l}\text { Sediment } \\
\text { wedge(s) }\end{array}$ & Geometry and sedimentary architecture \\
\hline George Bligh & $\begin{array}{l}\text { Prograding to aggrading sediment wedge that downlaps onto basal lava sequence. Extends } ~ 30 \text { km along southeast } \\
\text { margin of George Bligh High; is } \sim 20 \mathrm{~km} \text { wide. Possible lowstand between progradational and aggradational phases? } \\
\text { Southeastern (distal) edge of wedge has been displaced by mass failure during marginal collapse of the Rockall Basin. } \\
\end{array}$ \\
& Wedge displays general tilting towards Rockall Basin,
\end{tabular}

East Rockall Prograding to aggrading sediment wedge that downlaps onto basal pillow lava sequence. Extends 80-90 km along strike of Rockall High; is 15-20 km wide. Easterly tilt of internal reflections a function of contemporary tectonism. Eastern (distal) edge of wedge has been displaced by mass failure during marginal collapse of the Rockall Basin.

North Rockall Poorly developed prograding sediment wedge, progradational form not very clear and is inferred by assumed equivalence to the East Rockall wedge. Extends $\sim 30 \mathrm{~km}$ along northern margin of Rockall High, is $\sim 3-4 \mathrm{~km}$ wide. Northern (distal) edge of wedge has been displaced by mass failure during marginal collapse of the Rockall Basin.

NW Rockall Prograding sediment wedge that downlaps onto basal lava sequence. Capped by aggradational package? However, it is possible that an upper basalt unit is capping the wedge to the south (bankwards) of the observed progradation. Extends $\sim 35 \mathrm{~km}$ along northwestern margin of Rockall High; is $~ 10 \mathrm{~km}$ wide. Northern (distal) edge of wedge has been displaced by mass failure during marginal collapse of the Rockall Basin. General overall tilting of wedge towards the Rockall Basin.

West Rockall Prograding to aggrading sediment wedge that downlaps onto, and is overlain by, basinal Eocene sediments. Extends $\sim 90 \mathrm{~km}$ along the western margin of Rockall High; is $\sim 12 \mathrm{~km}$ wide. Two wedges have been mapped, but it is suspected that they are the same wedge system. Western (distal) edge of the wedge becomes conformable with the basinal fill between Swithin igneous centre and Rockall High. General overall tilting of wedge towards Hatton Basin.

East Swithin Prograding sediment wedge that downlaps onto, and is overlain by, basinal Eocene sediments. This wedge post-dates, and immediately overlies, the distal part of the West Rockall wedge. Extends $~ 28 \mathrm{~km}$ along the eastern flank of Swithin igneous centre; it is $\sim 16 \mathrm{~km}$ wide. The northeastern (distal) edge of the wedge becomes conformable with the basinal fill between the Swithin igneous centre and Rockall High. Wedge displays no significant tilting.

East Lyonesse Prograding to aggrading sediment wedge that downlaps onto basal lava sequence. It is possible that an upper basalt unit is capping the lower half of the wedge to the west of the observed progradation Extends $\sim 65 \mathrm{~km}$ along the eastern flank of Lyonesse igneous centre; it is $\sim 6 \mathrm{~km}$ wide. Eastern (distal) edge of wedge has been displaced by mass failure during marginal collapse of the Hatton Basin. Some tilting of internal reflections towards the Hatton Basin.

Lyonesse $\quad$ Aggrading sediment wedge that downlaps onto basal lava sequence, with no overburden (i.e. exposed at sea bed). Situated just eastwards of the crest of Lyonesse igneous centre: dimensions $\sim 12$ x $10 \mathrm{~km}$. Distal (eastern) edge of the wedge thins to zero thickness, revealing basalt at, or very near, sea bed. No significant tilting towards the Hatton Basin.

Sandarro Prograding to aggrading sediment wedge that downlaps onto basal lava sequence, with no overburden (i.e. exposed at sea bed). Situated just southwards of the crest of Sandarro igneous centre: dimensions $\sim 28$ x $18 \mathrm{~km}$. Distal (southern) edge of the wedge thins to zero thickness, revealing basalt at, or very near, sea bed. Slight overall tilting of wedge towards the Hatton Basin.

Central Hatton Prograding sediment wedge that downlaps onto, and is overlain by, basinal Eocene sediments. Extends $\sim 46 \mathrm{~km}$ along the strike of central Hatton Bank; it is $32 \mathrm{~km}$ wide. The eastern (distal) edge of the wedge becomes conformable with the basinal fill between Lyonesse igneous centre and Hatton High. Top is eroded and truncated. Possible overall tilting towards Hatton Basin.

North Hatton Prograding sediment wedge that downlaps onto basinal Eocene sediments. The top of the wedge has been interpreted as C30. The wedge clearly postdates the Central Hatton wedge, and is speculated to represent the latest stage of

Thickness $(\mathrm{m})^{\mathrm{a}}$

Up to 200

Up to 400

(sediments \&

lavas)

At least 110

Up to 200

Up to 140

Up to 70

Up to 200

Up to 100

Up to 150

Up to 100 wedge development in the Hatton-Rockall area. Extends 165 km along the strike of north Hatton High; it is $~ 18 \mathrm{~km}$ wide. The eastern (distal) edge of the wedge thins to zero, where C30 then marks the top of the basinal sequence in the Hatton Basin. Entire wedge is tilted eastwards towards Hatton Basin. 


\section{Table 6}

\begin{tabular}{|c|c|c|c|c|}
\hline Borehole & Depth (m bsb) & Lithology & Biozone & Prograding wedge \\
\hline \multirow[t]{3}{*}{$94 / 2$} & 4.81-19.33 & $\begin{array}{l}\text { Dark green-grey to brown, very coarse grained sandstone and pebbly sandstone, } \\
\text { dominated by glauconite, glauconized volcanic grains and bioclastic fragments, } \\
\text { set in a muddy carbonate matrix; on, basal conglomerate, poorly sorted and } \\
\text { disorganised, matrix supported, including shell material set in coarse sandstone } \\
\text { matrix. }\end{array}$ & NP 16-17 & \multirow{3}{*}{$\begin{array}{l}\text { East Rockall Wedge: } \\
\text { borehole located on SW } \\
\text { feather-edge of wedge, } \\
\text { and did not penetrate } \\
\text { lowermost sediment } \\
\text { package overlying } \\
\text { basalt. }\end{array}$} \\
\hline & $19.33-20.94$ & $\begin{array}{l}\text { Pale green, fine to very coarse grained, calcareous sandstone, dominated by } \\
\text { quartz,K-feldspar, glauconite, glauconized volcanic grains, with rare bioclastic } \\
\text { material, and tabular zeolite in pores; on thin ( } 0.13 \mathrm{~m} \text { thick) calcareous } \\
\text { mudstone, some bioclastic and tuffaceous (?) material, and incorporating } \\
\text { brecciated basaltic fragments at base. }\end{array}$ & NP 13-14 & \\
\hline & $\begin{array}{l}\text { 20.94-22.15 } \\
\text { (TD) }\end{array}$ & Dark grey basalt with thin, interbedded, greenish-grey tuff & & \\
\hline \multirow[t]{2}{*}{$94 / 6$} & $8.94-17.86$ & $\begin{array}{l}\text { Varicoloured dark yellowish brown to dark brown to dark greenish grey, fine to } \\
\text { medium grained, friable, poorly sorted, non-calcareous sandstone dominated by } \\
\text { basaltic volcaniclastic grains. }\end{array}$ & NP14-15 & \multirow{2}{*}{$\begin{array}{l}\text { NW Rockall Wedge: } \\
\text { borehole located on SE } \\
\text { feather-edge of wedge, } \\
\text { and did not penetrate } \\
\text { lower sediment packages } \\
\text { overlying basalt }\end{array}$} \\
\hline & $\begin{array}{l}17.86-21.90 \\
\text { (TD) }\end{array}$ & $\begin{array}{l}\text { Basalt cobbles (17.86-18.00 m) on dark grey, fine-medium grained, } \\
\text { amygdaloidal basalt }\end{array}$ & & \\
\hline \multirow[t]{2}{*}{$94 / 7$} & $10.60-20.97$ & $\begin{array}{l}\text { Buff to pale grey and pale yellowish brown, porous, hard, fine to coarse grained, } \\
\text { bioclastic limestone; abundant fragments of bryozoa, bivalves, echinoid plates } \\
\text { and spines, serpulid fragments and foraminifera tests set in sparry calcite } \\
\text { cement. Minor, altered, volcaniclastic grains. }\end{array}$ & NP15-18 & \multirow{2}{*}{$\begin{array}{l}\text { George Bligh Wedge: } \\
\text { borehole located on NW } \\
\text { feather-edge of wedge, } \\
\text { and did not penetrate } \\
\text { lower sediment packages } \\
\text { overlying basalt }\end{array}$} \\
\hline & $\begin{array}{l}20.97-23.55 \\
\text { (TD) }\end{array}$ & $\begin{array}{l}\text { Thin coarse-grained sand and cobble lag }(20.91-20.97 \mathrm{~m}) \text { on dark grey to very } \\
\text { dark grey, fractured, medium grained, slightly amygdaloidal basalt flows, } \\
\text { separated by very thin }(<1 \mathrm{~cm}) \text {, very poorly sorted, fine to very coarse grained, } \\
\text { shelly sandstone that incorporates organic material, including a leaf impression. }\end{array}$ & & \\
\hline
\end{tabular}

